UNIVERSIDADE DE SÃo PAULO

FACULDADE DE EDUCAÇÃO

MAURO SOARES CORDEIRO

\title{
POLÍTICA EDUCACIONAL
}

ELABORAÇÃO E CONTINUIDADE

O PROGRAMA EDUCOM.RÁDIO NAS ESCOLAS MUNICIPAIS

DA CAPITAL DE SÃO PAULO 
MAURO SOARES CORDEIRO

POLÍTICA EDUCACIONAL

ELABORAÇÃO E CONTINUIDADE

O PROGRAMA EDUCOM.RÁDIO NAS ESCOLAS MUNICIPAIS

DA CAPITAL DE SÃO PAULO

Dissertação apresentada ao Programa de PósGraduação em Educação da Faculdade de Educação da Universidade de São Paulo para a obtenção do título de Mestre na área de concentração: Sociologia da Educação, sob orientação do Prof. Dr. Elie Ghanem.

São Paulo

2009 
Autorizo a reprodução e divulgação total ou parcial deste trabalho, por qualquer meio convencional ou eletrônico, para fins de estudo e pesquisa, desde que citada a fonte.

Catalogação na Publicação

Serviço de Biblioteca e Documentação

Faculdade de Educação da Universidade de São Paulo

379.5(81.61) Cordeiro, Mauro Soares

C794p Política educacional, elaboração e continuidade : o programa Educom.rádio nas escolas municipais da capital de São Paulo / Mauro Soares Cordeiro ; orientação Elie Ghanem. São Paulo : s.n., 2009. $125 \mathrm{p}$.

Dissertação (Mestrado - Programa de Pós-Graduação em Educação.Área de Concentração : Sociologia da Educação) - - Faculdade de Educação da Universidade de São Paulo.

1. Política educacional - São Paulo, SP 2. Escola pública 3. Rádio (meio de comunicação) 4. Formulação de políticas I. Ghanem, Elie, orient. 


\section{FOLHA DE APROVAÇÃO}

Mauro Soares Cordeiro.

Política Educacional, Elaboração e

Continuidade: o Programa Educom.rádio nas

Escolas Municipais da Capital de São Paulo.

Dissertação apresentada ao Programa de PósGraduação em Educação da Faculdade de Educação da Universidade de São Paulo para a obtenção do título de Mestre na área de concentração: Sociologia da Educação, sob orientação do Prof. Dr. Elie Ghanem.

Aprovado em

Banca Examinadora

Prof. Dr.

Instituição Assinatura

Prof. Dr.

Instituição Assinatura

Prof. Dr.

Instituição Assinatura 
Às escolas públicas. 
À Aline Abbonizio, pelos incentivos aos processos de decisão que levaram a este trabalho e pelo amor que me revelou com a sentença greetings and love to one and all.

Ao He's_Bolah, que dividindo o mundo comigo o tornou menos grave.

À Jana, pela demonstração de que as loucuras da vida têm sentido.

Ao meu orientador nesta pesquisa: Elie Ghanem. Pelos inestimáveis subsídios estimulados com a permissão de exame da terceira gaveta de seu arquivo. Por ter me apresentado à densidade dos estudos destilados por mr. Jonh Daniel's, sem os quais esta dissertação não teria meios nem o perfume dela. Também por ter contribuído para transformar minha angústia em problema e minha esperança em hipótese. Maestro, obrigado!

Aos meus irmãos: Denilson, pelo discernimento da iniciação; pela mestria da madureza. Marli, pela bondade poética. Márcio, pela arte da rua. Lilian, pela compreensão de caçula. A todos, pelo prazer de terem me tornado tio.

À minha mãe, Zilda Soares Cordeiro, por observar a astúcia de que na vida tudo é jeito: de um nó a atarracar a pena.

Ao meu pai [in memoriam], Antônio Cordeiro Sobrinho, pelo legado que deixou na lógica da jogatina e da pesca.

À Anarina de Bandeira, pelo sopro de esperança em viver de brisa no Nordeste.

Ao Lubambo F.C. que na Chuva e no Sol decidiu campeonatos em campos adversos: 1. Jão (Lagarantia); 3. Luonça (Rancatoco); 4 Fabi (Patadura); 5. Eder (Jacaferrolho); 6. Pedro (Esquerdaenfúria); 7. Daniel (Cabecinhadeoro); 8. Lelo (Namedida); 9. Sebá (Porlacarretera); 10. Fernando (Demoniodasdeiz); 11. Fran (Elmatador). Ainda aos canhoteiros Glauco e Sheid. E, claro, obrigado pelo carinho desta torcida maravilhosa!

Aos grupos político-artístico-desportivos: $5^{\mathrm{a}} \mathrm{F}$, TdaB; Vivos \& Aparecidos Políticos; Rádio Livre; Unidos da Lonapreta; Cinema de Guerrilha; Mozum, pelas experiências formadoras.

Aos colegas de curso e amigos na universidade: Carol, Cinthia, Edu, Felipe, Fernando, Francine, Hamilton, Juliana, Luciana, Rafael, Raquel; pelo convívio cordial e prestimoso.

À Juliana e à Ynaê, por cederem o telefone para que eu contatasse as escolas.

Ao Tuto (Oswaldo) e ao Fabinho, também pelas indicações bibliográficas.

À Márcia Ferreira e ao Wilson Mesquita, pelos debates travados na ANPEd 2008.

Aos amigos de NCE: Eliany, Patrícia, Raphael, Robson.

Às professoras Marlene Suano e Teresa Caldeira, pelo incentivo à pesquisa.

Às professoras Flávia Schilling e Vivian Urquidi, pela generosidade das argüições feitas na qualificação desta pesquisa.

À Memória Técnica Documental da Secretaria Municipal de Educação de São Paulo.

Ao pessoal que trabalha no gabinete do vereador Carlos Neder.

À Ana Zamboni e ao Sergio Gomes, da Oboré.

Aos funcionários da biblioteca desta Feusp.

A todas as pessoas que cederam entrevistas e que colaboraram com informações nesta pesquisa. 
Abri caminho até o centro e fiquei justo ao lado do croupier; comecei logo a tentear timidamente o jogo, apostando duas ou três moedas. Enquanto isso, observava e anotava; parece-me que todos os cálculos individuais significam muito pouco e não têm absolutamente a importância que muitos jogadores the atribuem. Eles ficam ali sentados com suas folhas de papel todas rabiscadas, tomam nota dos números que saem, fazem contas, pesam as chances, calculam, afinal apostam... e perdem, tal qual como nós, pobres mortais que jogamos sem calcular. Mas, em troca, cheguei a uma conclusão que considero justa: de fato, no curso das chances fortuitas, há, senão um sistema, pelo menos algo semelhante a uma ordem, o que, por certo, é muito estranho.

Aleksei Ivanovitch

Vamos referir-nos muitas vezes às interações políticas, mediante as quais as pessoas se influenciam reciprocamente, como o 'jogo do poder'. Por que 'jogo'? Porque queremos evocar o que acontece, por exemplo, no xadrez, ou numa partida de futebol. A expressão 'jogo do poder' sugere um conjunto de inter-relações mais complexas e mais íntimas do que o termo genérico 'política', ou o simples 'inter-relacionamento'.

Charles Lindblom

Olhe: o que devia de haver, era de se reunirem-se os sábios, políticos, constituições gradas, fecharem o definitivo a noção - proclamar por uma vez, artes assembléias, que não tem diabo nenhum, não existe, não pode. Valor de lei! Só assim davam tranqüilidade boa à gente. Por que o Governo não cuida?! [...] Uma coisa é pôr idéias arranjadas, outra é lidar com país de pessoas, de carne e sangue, de mil-e-tantas misérias... Tanta gente - dá susto de saber - e nenhum se sossega: todos nascendo, crescendo, se casando, querendo colocação de emprego, comida, saúde, riqueza, ser importante, querendo chuva e negócios bons... 
CORDEIRO, Mauro Soares. Política educacional, elaboração e continuidade: o programa Educom.rádio nas escolas municipais da Capital de São Paulo. 2009. 118 f. Dissertação (Mestrado) - Faculdade de Educação da Universidade de São Paulo. São Paulo, 2009.

Trata-se de pesquisa sobre processos de decisão em elaboração e continuidade de programas de educação escolar pública, examinando o programa Educom.rádio, da prefeitura de São Paulo. Propôs-se o problema: a forma de elaboração do programa influiu muito na sua continuidade? Forma de elaboração foi entendida como participação na elaboração, significando que quanto maior o número e mais variados os tipos de agentes participantes da elaboração de uma política, programa ou projeto, mais numerosos e variados agentes tenderão a querer a realização do que foi elaborado, portanto, a inclinar-se por sua permanência. A hipótese principal foi que as formas de elaboração de programas influem em sua continuidade, portanto, buscou-se verificar se a forma de elaboração do programa Educom.rádio influiu muito em sua continuidade. Para caracterizar a forma de elaboração do programa Educom.rádio quanto ao número e variedade de indivíduos e grupos participantes, o trabalho se baseou nas entrevistas realizadas com pessoas que participaram da tomada de decisão sobre o programa. Os depoimentos serviram também para balizar as diretrizes e critérios envolvidos nas decisões que levaram à adoção do programa e à sua continuidade. Foram examinados documentos oficiais sobre o programa. Foi apurado, por meio de levantamento por questionário junto às escolas, que a continuidade do programa se dá também na sua operacionalização direta com a população beneficiária. Concluiu-se que as decisões fundamentais concernentes ao programa Educom.rádio, tanto para o processo de elaboração quanto para sua continuidade, foram tomadas por diretrizes e critérios de poucas pessoas, todas situadas no nível superior do setor educacional do município de São Paulo. Pode-se observar que o fator forma de elaboração entendida como a participação na elaboração não foi preponderante para a continuidade do programa.

Palavras-chave: política educacional; rádio; participação; elaboração; continuidade 
CORDEIRO, Mauro Soares. Politique scolaire, élaboration et continuité: le programme Educom.rádio dans les écoles municipales de la ville de São Paulo. 2009. 118 f. Dissertation Faculdade de Educação da Universidade de São Paulo. São Paulo, 2009.

Il s'agit d'une recherche sur des procédures de décision dans élaboration et continuité de programmes d'éducation scolaire publique, en examinant le programme Educom.rádio, de la Mairie de São Paulo. C'est proposé le problème : la forme d'élaboration du programme a beaucoup influencé sa continuité? Forme d'élaboration a été comprise comme la participation dans l'élaboration, en signifiant que plus grand le nombre et plus variés les types d'agents participants de l'élaboration d'une politique, programme ou projet, plus nombreux et variés aussi des agents tendront à vouloir la réalisation dont il a été élaboré, donc, à s'incliner par sa permanence. L'hypothèse principale a été que les formes d'élaboration de programmes influencent dans leur continuité, donc, on a cherché vérifier si la forme d'élaboration du programme Educom.rádio a influencé beaucoup dans sa continuité. Pour caractériser la forme d'élaboration du programme Educom.rádio en ce que concerne au nombre et à la variété de personnes et de groupes participants, le travail s'est basé sur les interviews réalisées avec des personnes qui ont participé de la prise de décision sur le programme. Les récits ont servi aussi pour baliser les directives et les critères impliqués dans les décisions qui ont pris à l'adoption du programme et à leur continuité. On a examiné des documents officiels sur le programme. On a conclu, par questionnaire auprès des écoles, que la continuité du programme est possible grace aussi à sa mise en place directe avec la population bénéficiaire. On a conclu encore que les décisions fondamentales liées au programme Educom.rádio, aussi pour la procédure d'élaboration que pour leur continuité, ont été pris par des directives et des critères de peu de gents, toutes placées au niveau supérieur du secteur scolaire de la ville de São Paulo. On a pu observé que la forme d'élaboration considérée comme la participation dans l'élaboration n'a pas été prépondérante pour la continuité du programme.

Mot-clés: politique scolaire; radio; participation; élaboration; continuité. 


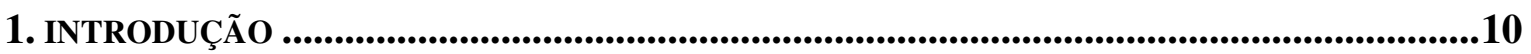

2. HISTÓRICO DO PROGRAMA EDUCOM.RÁDIO _...........................................................13

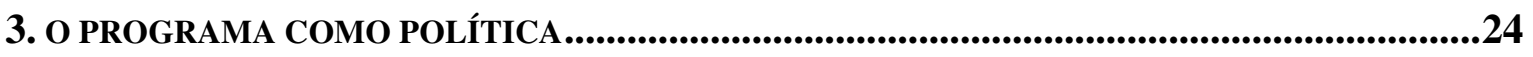

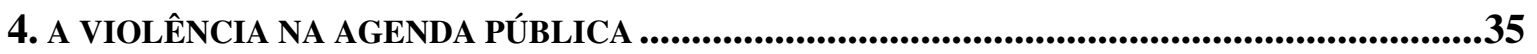

5. A ELABORAÇÃ̃ DO PROGRAMA EDUCOM.RÁDIO ......................................................46

6. A CONTINUIDADE ..................................................................................................................................65

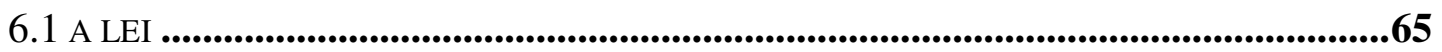

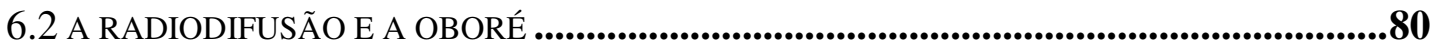

6.3 O DECRETO...............................................................................................................................86

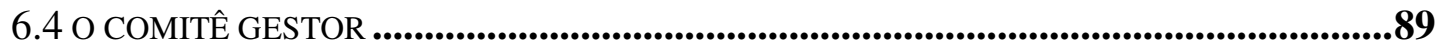

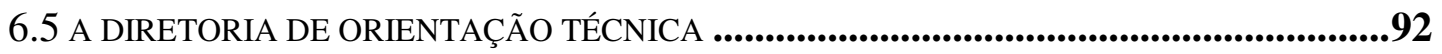

6.6 A CONTINUIDADE DO PROGRAMA ENTRE 2006 E 2008 ...................................................101

6.7 A PERMANÊNCIA DO PROGRAMA NAS ESCOLAS ..............................................................108

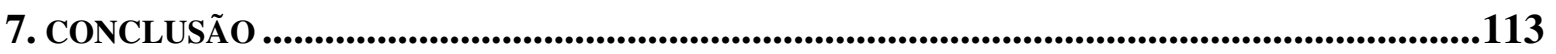

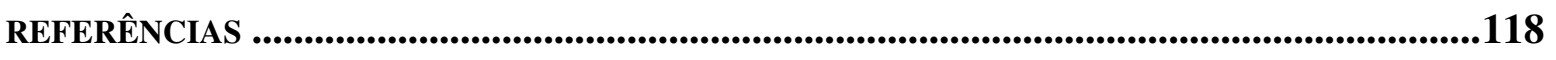

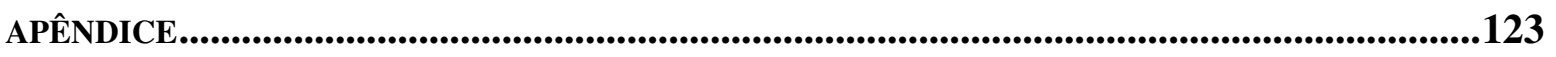




\section{INTRODUÇÃO}

Esta pesquisa foi empreendida com o propósito de compreender o processo de decisão que leva à adoção de programas no campo das políticas em educação. Para entender os fatores em jogo nos processos de decisão, dirigiu-se às variações das relações políticas que determinam formas de elaboração de programas, bem como buscou-se estabelecer seus nexos com o aspecto da continuidade de programas. Isso foi feito com o caso do programa Educom.rádio a partir do problema: a forma de elaboração do programa influiu muito na sua continuidade?

Meu envolvimento com o programa Educom.rádio (pronuncia-se Educom ponto rádio) se deu quando comecei a trabalhar em sua implantação, contratado pelo Núcleo de Comunicação e Educação da Escola de Comunicações e Artes da Universidade de São Paulo (NCEECA/USP, daqui para diante, nomeado apenas com a sigla NCE).

Trabalhei como mediador do programa de agosto de 2003 a dezembro de 2004. Mediador era a designação dada a quem servia como agente direto de formação de pessoas nas escolas municipais da capital de São Paulo para aprenderem a fazer programação de rádio.

O Educom.rádio é um programa da Secretaria Municipal de Educação de São Paulo, implantado a partir do segundo semestre de 2001, naquelas escolas públicas. Teve início com a parceria entre o Projeto Vida, vinculado ao Gabinete do Secretário Municipal de Educação de São Paulo, e o NCE. O programa se destina a instruir docentes e estudantes do ensino fundamental para práticas de comunicação por meio da linguagem radiofônica em ambiente escolar. Durante a implantação sob a responsabilidade do NCE (setembro de 2001 a dezembro de 2004), participaram do programa 453 escolas municipais de ensino fundamental da capital de São Paulo. 
Em dezembro de 2004, a prefeita Marta Suplicy assinou a Lei $n^{\circ} 13.941$ que instituiu o Programa Educom no Município de São Paulo. A partir de 2005, o NCE deixou de ser responsável pela implantação do programa. Esse Núcleo havia sido contratado para a implantação do programa até aquele ano, conforme previsto em documento firmado com a Secretaria Municipal de Educação. Com a mudança de prefeitos, o programa passou por um breve período de suspensão e foi retomado com a publicação do Decreto $\mathrm{n}^{\circ} 46.211$, assinado pelo prefeito José Serra em agosto de 2005. Esse decreto instituiu um comitê gestor responsável pelo programa.

O programa atravessou a turbulência advinda da mudança de prefeitos: fim do governo Marta Suplicy (PT), em 2004, e início do governo José Serra (PSDB)/Gilberto Kassab (PFL ${ }^{1}$ ), em 2005. No próprio mandato de Marta Suplicy, houve troca de titulares da Secretaria Municipal de Educação: Fernando de Almeida (Secretário da Educação de janeiro de 2001 a fevereiro de 2002); Eny Marisa Maia (fevereiro a dezembro de 2002); Maria Aparecida Perez (março de 2003 a dezembro de 2004). Também a coordenação do Projeto Vida teve sua composição alterada, Dirce Gomes foi substituída por Matias Vieira, em 2003. Todos esses fatos se somam como dificuldades para a continuidade do programa. Entretanto, este se manteve.

Nossa hipótese principal foi a de que as formas de elaboração de programas influem em sua continuidade. Buscou-se verificar se a forma de elaboração do programa Educom.rádio influiu muito em sua continuidade. Forma de elaboração foi entendida como participação na elaboração, significando que quanto maior o número e mais variados os tipos de agentes participantes da elaboração de uma política, programa ou projeto, mais numerosos e variados agentes tenderão a querer a realização do que foi elaborado, portanto, a inclinar-se por sua permanência.

\footnotetext{
${ }^{1}$ Atual Democratas (DEM).
} 
Para testar a veracidade dessa hipótese, esta pesquisa procurou verificar: a) se da elaboração do programa participou um conjunto numeroso de pessoas e de variados tipos; b) que a proposta e a execução do programa não se alteraram substancialmente em certo período (2001 a 2007).

Como objetivos, buscou-se caracterizar a forma de elaboração do programa Educom.rádio quanto ao número e variedade de indivíduos e grupos participantes, assim como identificar os elementos de permanência do programa. 


\section{HISTÓRICO DO PROGRAMA EDUCOM.RÁDIO}

Este histórico do programa Educom.rádio adotou como principais fontes de informações as descrições dos documentos oficiais produzidos pela Secretaria Municipal de Educação de São Paulo encontrados no setor Memória Técnica Documental, que faz parte daquela Secretaria. Outros foram encontrados no acervo do gabinete do vereador Carlos Neder na Câmara Municipal de São Paulo.

O programa Educom.rádio começou a ser implantado pela Secretaria Municipal de Educação de São Paulo em 2001, durante o governo de Marta Suplicy à frente do Executivo Municipal em São Paulo. Foi elaborado para ser uma das ações desenvolvidas pelo Projeto Vida com a justificativa anunciada de conferir cumprimento à lei no 13.096 (Programa de Prevenção da Violência nas Escolas), de 8 de dezembro de 2000.

O contrato para execução foi firmado entre o NCE e a Secretaria Municipal de Educação. Esse contrato é intitulado Programa Educom: educomunicação pelas ondas do rádio: construindo a paz pela comunicação. Consta a Secretaria Municipal de Educação de São Paulo como contratante e a Fusp (Fundação de Apoio à Universidade de São Paulo) como contratada. Os responsáveis pelo programa são, no contrato, Antonio Marcos de Aguirra Massola (diretor executivo da Fusp) e Ismar de Oliveira Soares (coordenador do NCE-CCAECA/USP). Esse contrato foi o que deu início à implantação do programa Educom.rádio nas escolas de ensino fundamental da rede municipal de educação paulistana. O documento é composto por: objetivo; resultado esperado; metodologia; número de turmas; número de participantes; total de horas/atividades; conteúdos por módulos; justificativa; certificados acadêmicos. Como objetivo, o documento atesta que se trata de (NCE-ECA/USP, 2001a, p.1): 
desenvolver diferentes modos de comunicação na sala de aula e no conjunto das atividades educativas, privilegiando-se, nesse contexto, o emprego da linguagem radiofônica.

Como resultados, a intenção era a de que as pessoas que participassem da formação proposta pelo programa fossem capazes de "identificar caminhos metodológicos para o uso da educomunicação de acordo com o que inspira a nova LDB" e ficassem habilitadas a trabalhar com a linguagem e a tecnologia radiofônica. A metodologia seria "um conjunto seriado de atividades de capacitação" e "assistência pedagógica e técnica” (NCE-ECA/USP, 2001a, p.3).

No item Número de turmas, o contrato previa que o programa capacitaria as turmas em escala crescente, de acordo com um quadro no qual apresenta o curso divido em 7 fases, sendo que cada fase se realizaria em um semestre, com os respectivos números de turmas. Para chegar ao número de participantes, foi sugerido o cálculo de 20 docentes de escolas municipais (chamados de educadores) integrando cada turma. No quesito horas/atividades, o documento afirma que cada turma desenvolveria 100 horas de atividades.

O contrato estipulou que o programa seria dividido em três módulos, subdivididos em seis tipos de atividades. O primeiro módulo foi denominado Pensando o ecossistema educomunicacional, compreendendo as atividades Workshops sobre educomunicação e Oficinas pedagógicas de rádio. O segundo, Educomunicação em ação, continha as atividades Encontros temáticos sobre a comunicação na construção da paz; Planejando e avaliando a educomunicação; Práticas laboratoriais em multimídia; e $O$ educomunicador em avaliação. O terceiro módulo teve o mesmo nome da sexta atividade proposta, ou seja, $O$ educomunicador em avaliação.

A justificativa do programa constante no contrato é composta das seguintes passagens: 
estudos têm demonstrado que o Mundo da Comunicação nem sempre está sintonizado com o Mundo da Educação [...].

O Projeto Vida, da Secretaria Municipal de Educação, entende estar oferecendo uma efetiva contribuição à rede pública de educação do Município ao criar condições para que grupos de educadores de cada uma de suas escolas de ensino fundamental e médio tenha a ocasião de tomar parte numa experiência de planejamento e execução de ações educomunicativas, a partir de uma convivência entre especialistas do NCE/ECA/USP, docentes e alunos das escolas do município. (NCE-ECA/USP, 2001a, p. 7-8).

No item Certificados acadêmicos, consta que o programa ofereceria "aos que dele participarem integralmente três certificados de extensão universitária, correspondentes a três cursos de 32 horas, oferecidos pela Universidade de São Paulo". (NCE-ECA/USP, 2001a, p.10).

No módulo denominado Workshops sobre educomunicação (20 horas), há uma sucinta referência à forma pela qual seriam abordadas "as causas da violência de que são vítimas [crianças e jovens] ou de que participam e os possíveis caminhos para sua superação". (NCEECA/USP, 2001a, p. 5).

Na justificativa do programa, presente no contrato, não há referência a dados sobre violência ou formas de obliterá-la. Tão pouco descreve como a comunicação contribuiria para a prevenção da violência nas escolas, objetivo do Projeto Vida (que será examinado mais adiante).

Em linhas gerais, esse contrato que deu forma ao programa foi executado, entre 2001 e 2004, da seguinte maneira: 
De setembro a dezembro de 2001, o NCE implementou o programa em 26 escolas, sendo duas escolas de cada um dos $13 \mathrm{NAEs}^{2}$. Essa foi considerada a primeira fase do programa prevista no contrato e foi realizada por meio de atividades de discussão sobre educomunicação e oficinas sobre produção radiofônica. Foi estruturada em 12 encontros presenciais de 8 horas cada, divididos em 3 módulos. Esses encontros eram realizados em uma das escolas, denominada pólo. Na primeira fase, as escolas foram divididas em 5 pólos com variação entre 4 e 7 escolas cada. A escola-pólo recebia os cursistas das outras escolas. A equipe de formação de cada pólo era constituída por um articulador e um capacitador, somado a um monitor para adultos e um para estudantes (FUNARI, 2007, p. 221).

De março a junho de 2002, foi desenvolvida a segunda fase, atendendo a 40 escolas, por volta de 3 escolas de cada NAE (apenas o NAE 3 teve 4 escolas envolvidas na formação). Nessa fase, os pólos coincidiam com os NAEs. Assim, a formação se distribuiu em 13 pólos, em 12 encontros.

Em 3 de agosto de 2002, teve início a terceira fase do programa e atendeu a 52 escolas, também distribuídas pelos 13 NAEs e em 12 encontros.

$\mathrm{Na}$ fase quatro, o número de cursistas chegou a 1.300 de 65 escolas que participaram. Nessa fase a formação das equipes responsáveis pela implantação do programa foi modificada. Cada equipe enviada a cada um dos pólos pelo NCE começou a contar com um articulador, que também era responsável pela formação da equipe, um assistente e os mediadores (um para cada escola). Os encontros de formação da equipe eram realizados em determinado dia da semana, escolhido pelas equipes. Nessa formação, a partir de um caderno de Orientações de Atividades (NCE-ECA/USP, 2004), eram debatidos temas concernentes à implantação do

\footnotetext{
${ }^{2}$ NAE é a sigla para se referir a Núcleo de Ação Educativa, órgão técnico-administrativo de nível intermediário ao qual está subordinado o conjunto de escolas municipais de uma região. Sua designação foi substituída por Coordenadoria de Educação e, posteriormente, por Diretoria de Educação.
} 
programa, bem como a confecção da agenda que seria executada no sábado de formação nos pólos: dia em que se dava, das 8 às 17h, a formação com as escolas. Basicamente, a programação do sábado se constituía da seguinte maneira: de manhã, docentes das escolas assistiam a uma palestra sobre algum tema (saúde; protagonismo juvenil; multiculturalimo, dentre outros); no mesmo horário, os estudantes debatiam o mesmo tema com os mediadores. A tarde era reservada à produção radiofônica. Gravava-se um programa de rádio de aproximadamente 3 minutos produzido por docentes e estudantes conjuntamente.

Na quinta fase, realizada no segundo semestre de 2003, 78 escolas participaram da formação. Foram distribuídas 6 escolas para cada um dos 13 pólos.

A sexta fase foi realizada no primeiro semestre de 2004 e teve 131 escolas participantes em 17 pólos.

A sétima e última fase sob responsabilidade do NCE e prevista no contrato inicial foi realizada no segundo semestre de 2004 em 68 escolas distribuídas em 10 pólos.

Os equipamentos de rádio para a montagem da estação nas escolas chegavam depois da formação. Existia uma equipe do NCE especificamente responsável por ir até as escolas ministrar o que se considerava como formação técnica. Essa formação consistia na visita de uma pessoa ligada ao NCE às escolas que tinham recebido o equipamento para apresentar seus componentes e formas de utilização; ligá-lo e demonstrar o funcionamento. Outro pessoal era responsável pela instalação dos equipamentos (antena de transmissão; caixas receptoras do sinal e demais componentes) onde melhor conviria a cada escola.

No relatório de gestão 2001-2004 do Projeto Vida, na parte das Ações desenvolvidas, são numeradas 8 ações. A primeira é o Projeto Educom.rádio (ao longo de todo esse documento, o programa Educom.rádio é mencionado como projeto) e seus objetivos: 
a) Desenvolver práticas pedagógicas, solidárias e colaborativas que permitam à comunidade escolar dar respostas adequadas e construtivas aos problemas da convivência diária, além de propiciar uma melhora na compreensão e na aprendizagem das várias linguagens próprias da sociedade da informação, conforme recomendam a LDB e os Parâmetros Curriculares para o Ensino Fundamental

b) Formar e capacitar alunos e educadores da comunidade na linguagem radiofônica

c) Resgatar a oralidade, ampliando assim a possibilidade de expressão dos alunos

d) Estimular a apropriação, pelos alunos e comunidade em geral, dos espaços públicos da cidade

e) Promover o estreitamento das relações intra-escolares, interescolares, e entre escola e comunidade

f) Ampliar a visão de Educação e o acesso ao conhecimento, favorecendo o desenvolvimento curricular

g) Assegurar o direito dos estudantes à cultura e ao lazer. (SÃO PAULO, [2004], p. 3).

O item B da descrição do programa Educom.rádio no documento é o Público-alvo. Considera o público do programa os "educadores e alunos". Mostra o número de beneficiados diretos que o programa alcançou: “11.245 pessoas, até dezembro de 2004. Formas de beneficiamento: formação; aquisição e implantação de um sistema de rádio de transmissão restrita em 455 escolas municipais de ensino fundamental da rede pública de educação" (SÃO PAULO, [2004], p. 4).

No entanto, essa forma de beneficiamento não se efetivou. A aquisição de sistema de rádio de transmissão restrita foi interrompida com a mudança de prefeitos. Até aquela data, por volta de 246 escolas tinham recebido o equipamento para a montagem do estúdio de rádio prevista no contrato para a efetivação do programa (SÃO PAULO, [2004a]).

$\mathrm{Na}$ descrição da experiência, item $\mathrm{C}$, o documento afirma que o programa: "facilita a aquisição dos conhecimentos e habilidades indispensáveis para que se introduzam e se 
promovam os diferentes modos de comunicação na sala de aula e no conjunto das atividades educativas". Ainda nesse item, apresenta uma tabela relacionando as fases do programa; duração; número de turmas; total de turmas; número de participantes por fase. O cálculo apontado no documento do contrato dizia que o número de participantes seria 20 docentes por turma, o que só ocorreu na $1^{\text {a }}$ fase (NCE-ECA/USP, 2001a, p. 3). Nas demais, o número é de 25 pessoas por turma. Não foi encontrado nenhum documento ou passagem em documento que evidenciasse o porquê de ter aumentado esse número e não se restringir mais a docentes de escolas municipais, referindo-se genericamente a "pessoas". O documento é pouco claro, também, quanto à forma de implantação do programa, apenas diz que "acontece em pólos, nas escolas, e é composto por um conjunto seriado de atividades de capacitação na linguagem radiofônica, incluindo conferências, workshops e oficinas" (SÃO PAULO, [2004], p. 5). Anuncia ainda que "ao completar a formação e a instalação/implantação do sistema de rádio, a unidade escolar trabalha a proposta dentro do projeto político-pedagógico fazendo os possíveis desdobramentos, de acordo com cada realidade local” (SÃO PAULO, [2004], p. 6).

No item D, é publicado o custo total do projeto: “a) (set/01 a dez/04) é de $\mathrm{R} \$ 5.967 .325,00 ; \mathrm{b}$ ) a fonte de recursos é uma dotação específica (Projeto Vida) da Secretaria Municipal de Educação" (SÃO PAULO, [2004], p. 6).

O documento lista também as outras ações que o Projeto Vida desenvolveu: Projeto Escola Aberta; Políticas Públicas de ações afirmativas; Projeto Vamos Combinar?; Curso Política e Cidadania na Escola; Observatório Escolar em Segurança Urbana; Produção de Materiais distribuídos nas escolas da rede municipal de ensino. Entretanto, a ação mais bem detalhada que o documento apresenta é a que diz respeito ao programa Educom.rádio. Fora este, apenas o Curso Política e Cidadania na Escola demonstra números referentes a gastos de verba: $\mathrm{R} \$ 168.000,00$. O Educom.rádio foi o programa (ou ação) mais caro desenvolvido pelo Projeto Vida. 
No documento intitulado Demonstrativo das ações do Projeto Vida de 2001 a 2004, há implícitas as diretrizes da Secretaria Municipal de Educação na seguinte passagem:

Ao iniciar os trabalhos desta gestão, a Secretaria Municipal de Educação diagnosticou que um dos desafios a ser enfrentado seria a questão da vulnerabilidade à violência presente nas escolas, afetando educadores, alunos e comunidade. Retratar um ambiente escolar violento era, não tão raro, pauta na mídia (TV, rádio e imprensa escrita). Se por um lado este quadro era reflexo da violência social, por outro, não podíamos negar ou "fechar os olhos" para esta situação. Tornou-se urgente encontrar propostas que rompessem este ciclo. Assim, em janeiro de 2001, foi criado o Projeto Vida, como um instrumento de suporte pedagógico ao trabalho das escolas da rede municipal de ensino e à comunidade, tendo como sustentação a Lei 13.096/00 (Programa de Prevenção da Violência nas Escolas) e a Lei 8069/90 (ECA - Estatuto da Criança e do Adolescente). (SÃO PAULO, 2004, p. 1).

São apresentadas as mesmas ações do documento anterior. No entanto, o programa

Educom.rádio é descrito com mais detalhes. Diz que o programa:

[...] tem se destacado como importante instrumento na construção de um espaço democrático e interativo da Unidade Educacional e seu entorno, contribuindo para a prevenção da violência e integração das ações pedagógicas ao cotidiano da comunidade escolar. (SÃO PAULO, 2004, p.2).

Mas não apresenta dados estatísticos ou pesquisas que comprovem essa afirmação. Esse documento apresenta a lista de componentes que fazem parte do equipamento "adquirido pela Coordenadoria de Educação" e que, no item Balanço, diz que há a "implantação de 455 estúdios de rádio em andamento".

Em documento com o título Relatório conclusivo, é feita argumentação dos benefícios alcançados pelo programa Educom.rádio. O documento faz rápida apresentação das Ações do Projeto Vida de 2001 a 2004 e dedica o resto a falar do Educom.rádio. Termina prevendo a continuidade e sugerindo a expansão do programa:

Frente ao exposto, acreditamos, que em continuidade, seja necessário a integração do Projeto Educom.rádio com todos projetos das Unidades 
Educacionais, em especial à Informática Educativa. Destacamos que as ações e discussões deste projeto devem compor a construção do Projeto Político Pedagógico e a organização curricular. (SÃO PAULO, 2004a, p. 3).

Durante a implantação sob a responsabilidade do NCE (setembro de 2001 a dezembro de 2004), participaram do programa 453 escolas municipais de ensino fundamental da capital de São Paulo. Ainda em 2004, o programa passa a ser um programa sob a responsabilidade da Diretoria de Orientação Técnica (DOT).

O programa permaneceu mesmo com a mudança de responsáveis pelos principais cargos no nível hierárquico superior de administração pública do setor educacional municipal paulistano. Essa mudança adveio do fim do governo de Marta Suplicy (PT), em 2004, e início do governo de José Serra (PSDB)/Gilberto Kassab (PFL), em 2005.

Esse fato chama a atenção porque, dentre os projetos e ações que o Projeto Vida desenvolveu entre 2001 e 2004 (entre outros, Escola Aberta, Vamos Combinar, Curso Política e Cidadania na Escola, Observatório Escolar em Segurança Urbana), apenas o programa Educom.rádio obteve atenção por parte das propostas apresentadas pela DOT para o ano de 2005 (SÃO PAULO, 2005, p. 30).

Houve a possibilidade de abandono do Educom.rádio também, já que o programa passou por uma suspensão momentânea. Desde dezembro de 2004, a implantação não foi mais realizada pelo NCE. No entanto, o Termo de encerramento de participação no programa Educom.rádio foi assinado pelos mediadores (responsáveis pela implantação, ligados ao NCE) apenas em abril de 2006, quando a Fusp (Fundação de Apoio à USP), responsável pela administração orçamentária do programa, quitou os pagamentos que tinham sido suspensos durante o segundo semestre de 2004, suspensão esta que encontrou justificativa na lei eleitoral (FUSP, 2006). A suspensão permaneceu com a mudança do governo municipal. 
Em 28 de dezembro de 2004, o Projeto de Lei n ${ }^{\circ}$ 556/02, do vereador Carlos Neder (PT), foi aprovado como a Lei $\mathrm{n}^{\mathrm{o}}$ 13.941. A prefeita Marta Suplicy (PT) institui, assim, o Programa Educom no Município de São Paulo (SÃO PAULO, 2004b). O Decreto $\mathrm{n}^{\text {o }}$ 46.211, que regulamentou o Programa Educom, foi publicado somente em 15 de agosto de 2005, assinado pelo prefeito José Serra (PSDB). A partir de então, o programa foi retomado. Nesse período suspensivo, podem-se perceber algumas transformações. Dentre as quais: o programa mudou de denominação e se chamou, até outubro de 2008, Nas ondas do rádio; a partir de novembro de 2008, é nomeado, no sítio da Secretaria Municipal de Educação de São Paulo, como Programa Educomunicação; suspendeu-se a compra de equipamentos de rádio prevista no planejamento inicial: das 453 escolas que contaram com a formação para montar uma rádio, 246 constam como escolas que os receberam; transmutaram-se objetivos e procedimento metodológico, pois a violência não aparece mais como problema a ser enfrentado pelo programa e suas práticas assumem o objetivo de ser "uso pedagógico das linguagens midiáticas no processo de ensino" (SÃO PAULO, 2008).

A partir de agosto de 2005, a Secretaria Municipal de Educação mantém um responsável por todos os assuntos relacionados ao programa. Trata-se de um professor de escola municipal. Houve também a instituição de um Comitê Gestor do programa com a sua regulamentação por meio da publicação do Decreto n ${ }^{\circ}$ 46.211. No entanto, o sítio da Secretaria na internet não contém informações sobre reuniões ou encontros dos membros que compõem tal comitê. Há apenas a menção de que o seu presidente é o mesmo funcionário público responsável pelo programa.

Em 27 de março de 2008, foi promovido, na Câmara Municipal de São Paulo, o seminário programa Nas Ondas do Rádio: a mídia e a tecnologia no espaço escolar. Realizado pelo gabinete do vereador Carlos Neder, esse seminário teve a pretensão de discutir "a mídia e a tecnologia no espaço escolar" e teve por objetivo: 
- $\quad$ Apresentar o Programa Nas Ondas do Rádio como proposta de ação pedagógica de promoção do protagonismo infanto-juvenil por meio da comunicação e da tecnologia da informação.

- Discutir a Educomunicação como proposta de política pública para na cidade.

- Apresentar o projeto que institui o Prêmio Educom que vai premiar, anualmente, o melhor projeto desenvolvido na rede municipal de ensino. (NEDER, 2008b).

Outras informações que possuem relevo de evidência quanto à continuidade do programa serão apresentadas e examinadas a seguir.

Não foi propósito desta pesquisa fazer uma avaliação exaustiva da atual condição em que o programa se apresenta. Nosso problema de pesquisa diz respeito às formas de elaboração de políticas, critérios para decisões e continuidade de programas. Interessa-se por elementos que revelem o exercício de poder e a participação em decisões de políticas. Nós nos esforçamos para demonstrar esse interesse nas próximas páginas. 


\section{O PROGRAMA COMO POLÍTICA}

Trata-se aqui de examinar a elaboração de um programa no setor da Educação. Diante do problema desta pesquisa, partiu-se em busca de definições do termo programa. O que se pode perceber é que tal definição tem estado ausente na literatura disponível. Mesmo os trabalhos que enfocam seus estudos de caso em programas governamentais, não se atêm à sua definição. O mais próximo que se conseguiu chegar do delineamento do termo foi dado por Benevides (2007). Segundo essa pesquisadora, pode-se entender uma política como um conjunto composto necessariamente por diretrizes, quadro de pessoal e recursos financeiros. As ações podem se realizar de modo duradouro ou sem prazo determinado e, assim, constituirão o que pode ser denominado de programa (informação verbal) ${ }^{3}$.

É comum, na literatura que trata de estudos sobre políticas implementadas por governos, denominá-las pelo neologismo políticas públicas. Melo (2000, p. 65) demarca a incidência do uso dessa expressão da seguinte maneira: "É curioso observar que a recente difusão e popularização da expressão política pública, em escala internacional, pode ser vista como um concomitante de processos de democratização e institucionalização liberal”. O autor informa também que, no Brasil, a consagração da expressão política pública no léxico político, que se deu a partir da década de 1990, pode ser entendida como consequiência do processo de democratização.

Lowi (1994, p. 8) salienta que a expressão política pública "é um termo engenhoso que reflete a interpenetração entre o governo liberal e a sociedade, insinuando a existência de uma flexibilidade e uma reciprocidade maiores do que permitem alguns sinônimos unilaterais tais como lei, estatuto, ordenação, édito e semelhantes".

\footnotetext{
${ }^{3}$ Informação fornecida por Maria Victoria Benevides na Faculdade de Educação da Universidade de São Paulo, em 2007.
} 
Souza (2003, p. 136) encontrou diversas definições e concluiu que não existe uma única, nem melhor, definição sobre o que venha a ser política pública. No entanto, as definições dão margem ao propósito desta pesquisa. Assim, decidiu-se por reproduzi-las com o intuito de recuperar o debate que vem sendo travado na literatura. Aquela autora resume assim as concepções contidas nos diversos estudos a que teve acesso e que tratam do termo:

Mead a define como um campo no estudo da política que analisa o governo à luz de grandes questões públicas. Lynn a vê como um conjunto específico de ações do governo que irão produzir efeitos específicos. Peters segue o mesmo veio: política pública é a soma das atividades dos governos, que agem diretamente ou através de delegação, e que influenciam a vida dos cidadãos. Dye sintetiza a definição de política pública como "o que o governo escolhe fazer ou não"45.

A partir de tais concepções, ela constata também que:

Outras definições enfatizam o papel da política pública na solução de problemas. Críticos dessas definições, que superestimam aspectos racionais e procedimentais das políticas públicas, argumentam que elas ignoram a essência da política pública, isto é, o embate em torno de idéias. Pode-se também acrescentar que, por concentrarem o foco no papel dos governos, essas definições deixam de lado o seu aspecto conflituoso e os limites que cercam as decisões governamentais. Deixam também de fora possibilidades de cooperação que podem ocorrer entre os governos e outras instituições. No entanto, definições de políticas públicas, mesmo as minimalistas, guiam o nosso olhar para o locus onde os embates em torno de interesses (preferências) ou de idéias se desenvolvem, ou seja, os governos.

Couto (2005, p. 97), ao empreender pesquisa para entender o problema De que maneira o arcabouço constitucional conforma a política competitiva, de modo a definir o espaço possível de produção de políticas públicas?, distinguiu três dimensões para política. A primeira seria a política constitucional (informa o autor que essa dimensão, em linguagem

\footnotetext{
${ }^{4}$ As obras dos autores citados são: MEAD, L. M. "Public policy: vison, potential, limitts". Policy Currents, fev. 1-4, 1995. LYNN, L. E. Designing public policy: a casebook on the role of policy analysis. Santa Monica, California, Goodyear, 1980. PETERS, B. G. American public policy. Chatham, N. J., Chatham House, 1986. DYE, Thomas D. Understanding public policy. Englewood Cliffs, N. J., Prentice-Hall, 1984. (apud Souza, 2003, p. 136).
} 
corrente no inglês, é denominada polity); a segunda, a da política competitiva (politics); a terceira, a política pública (policy).

A primeira dimensão anunciada pelo autor, a política constitucional, seria aquela que diz respeito à estrutura básica do Estado, que conteria a sua forma fundamental. A partir dela, pode-se dar contornos à natureza de um Estado em particular tendo em conta os direitos fundamentais que assegura e "os procedimentos que aciona para permitir a tomada de decisão pelos governantes e a participação política pelos governados”. Assim, seria possível definir uma política constitucional como "democrática em função dos procedimentos (quem governa e como governa), mas também como social, ou de bem-estar social, caso assegure a seus cidadãos direitos sociais mínimos ( o quê garante o Estado)" (COUTO, 2005, p. 95).

Na segunda dimensão, a política competitiva, política é entendida como jogo. Ela é própria da atividade política desenvolvida em determinada configuração estatal. Essa atividade seria eivada de diversas possibilidades: conflito, cooperação, alianças, vitórias, derrotas, empates, ganhos, perdas etc. "É do desenvolvimento desta atividade estatal que resultam as decisões de governo, por um lado, e que se transforma a estrutura estatal vigente, por outro" (COUTO, 2005, p. 96).

A terceira dimensão, a política pública, seria o resultado da atividade política em determinada configuração do Estado:

É política pública tudo aquilo que o Estado gera como um resultado de seu funcionamento ordinário. Podemos dizer, por isto, que a produção das políticas públicas é condicionada tanto pela política competitiva, como pela política constitucional, sendo que esta define duas coisas. Primeiramente, o parâmetro possível no âmbito do qual a competição política pode se desenvolver. Em segundo lugar, os conteúdos legítimos das políticas públicas concretizadas como um desfecho do jogo político - determinando os programas de ação governamental iniciados, interrompidos, alterados ou que têm prosseguimento. (COUTO, 2005, p. 96). 
Um autor que desenvolveu estudos com o propósito de apreender o aspecto político do processo de decisão como algo relativamente autônomo, porque, acredita, seja estruturado de uma maneira específica, foi Lamounier (1982). Ele constituiu um relatório com a finalidade de sugerir algumas diretrizes teóricas para análise de políticas públicas, que também servem de subsídio a esta pesquisa.

No relatório intitulado Análise de políticas públicas: quadro teórico-metodológico de referência, o autor estrutura o texto em forma de oito proposições. A primeira afirma que $a$ política é onipresente. Essa proposição seria a contraposição de uma noção do senso comum para a qual a política é uma atividade circunscrita e especializada. O autor defende que "é necessário partir da consideração básica de que toda política pública é uma forma de intervenção nas relações sociais; e que é também, por mais concentrado que seja o processo decisório, condicionada por interesses e expectativas sociais" (LAMOUNIER, 1982, p. 8).

A segunda proposição diz respeito ao processo, em vez de eventos discretos. Essa proposição leva a efeito "ver o sistema das políticas públicas como um processo em fluxo, que se caracteriza por constantes barganhas, pressões e contrapressões e não raro por redefinições do efeito das decisões". O autor afirma ainda que acentuar essa característica "implica explicar até mesmo a eventual discrepância de orientações ou a quase independência de certos setores como resultado da contínua presença de forças políticas interessadas em manter ou em alterar decisões e práticas" (LAMOUNIER, 1982, p. 9).

Na proposição de número três, com o título nem holismo, nem nominalismo, o autor define que "o poder se expressa na própria definição dos objetos do conflito social que se irão materializar sob a forma de política pública". Holismo, para o autor, seria "a tendência a ver toda e qualquer política pública como uma exigência ou requisito abstrato de um sistema também abstrato, ignorando o processo político inerente à tomada de decisões". Nominalismo 
é estabelecido como o oposto de holismo, ou seja, seria a tendência a tomar como "ponto de partida igualmente dogmático de que as decisões são auto-suficientes, estanques entre si” (LAMOUNIER, 1982, p. 11).

Comando hierárquico e barganha voluntária são extremos raríssimos é o título da proposição quatro. Essa proposição afirma que "não há dúvidas que estas duas noções [comando e barganha] apenas apontam para situações limites, empiricamente inexistentes". Para evidenciar sua afirmação, o autor exemplifica dizendo que "a maioria das decisões relevantes numa unidade política abrangente como o governo do Estado de São Paulo sem dúvida se dá numa zona intermediária entre aqueles dois limites conceituais" (LAMOUNIER, 1982, p. 12).

A proposição número cinco pretende esboçar uma abordagem mais concreta e operacional dos princípios desenvolvidos anteriormente. A partir da combinação de conceitos desenvolvidos, de forma independente, por três autores - Charles Lindblom, E. E. Schattschneider e Theodore Lowi - a proposição pretende discernir em três níveis distintos o aspecto propriamente político dos processos decisórios.

O primeiro nível é a agenda (Schattschneider): "O poder político se expressa na capacidade de determinar os objetos imediatos do conflito". O segundo, arenas: "os objetos da decisão política podem ser classificados em três arenas" (Lowi): distributiva, "a arena em que se transacionam interesses altamente divisíveis, chegando inclusive ao nível individual"; a regulatória, "cuja possibilidade de desagregação de interesses, ainda que ampla, é sensivelmente menor que a anterior, permitindo muitas vezes a identificação dos vencedores e perdedores do processo decisório"; e, finalmente, a redistributiva, "cujas decisões têm sempre um impacto muito agregado, abrangendo vastas categorias sociais”. O terceiro nível seria o das técnicas (Lindblom): "a seleção de técnicas específicas para a implantação de uma decisão pertence também ela ao reino da inventividade política, no qual se combinam razões 
propriamente técnicas com a substância de interesses diversos". Assim, o autor conclui a proposição afirmando que cumpre acompanhar a política "desde o momento que ela adquire relevo na agenda política, passando pelo momento em que é definida e decidida, até os estágios finais de sua operacionalização, tornando claro que o aspecto político não se interrompe em nenhum instante" (LAMOUNIER, 1982, p. 13).

Na proposição de número seis, o autor afirma que:

[...] o problema aqui é precisamente o de examinar como esse predomínio [das estruturas de cooptação sobre as estruturas de representação] é recriado (e eventualmente questionado) no processo político pelo qual se fixam as prioridades (agenda), pelo qual se estabelece o perfil efetivo dos problemas reconhecidos como objetos de decisão (arenas) e pelo qual se selecionam as técnicas específicas de implementação. (LAMOUNIER, 1982, p. 17).

Está sugerido na proposição sete que: "se deve considerar que a estruturação específica das políticas públicas afeta os incentivos e desincentivos, os benefícios e os custos da participação, mas não exaure a variedade daqueles ou destes” (LAMOUNIER, 1982, p. 19).

Por fim, a proposição de número oito afirma que "a problemática do Estado consiste precisamente em compreender como ele se acha permanentemente dividido entre as tendências à universalização e tendência à particularização dos interesses representados". E prossegue:

De um lado, referindo-se à estrutura (formal) do Estado como sendo em si mesma uma agenda, ela expressa um viés, ou seja, uma probabilidade de distorções sistemática na constelação de interesses que efetivamente alçam o processo decisório. Ao mesmo tempo, tomado no sentido mais estrito das proposições anteriores, o conceito de agenda é sensível às variações do processo político ao longo de diferentes períodos e conjunturas, os quais podem reforçar ou neutralizar em parte o viés embutido na própria estrutura formal e organizacional do Estado. Recupera-se, assim, uma área privativa da análise empírica e histórica, em vez de tomar como definição inicial o que se trata, precisamente, de comprovar pelo estudo de como se formulam e implementam as políticas públicas. (LAMOUNIER, 1982, p. 20). 
Marques (2006) confrontou diversos autores que realizaram estudos sobre políticas do Estado. Ele selecionou autores que trataram seus temas a partir da conformação de redes sociais para a análise de políticas públicas. O seu interesse foi examinar políticas concebidas e implementadas no setor urbanístico (um caso do Rio de Janeiro e outro de São Paulo).

Com essa perspectiva, ele constatou que, para aplicar a metodologia concernente à formação e atuação das redes sociais no contexto brasileiro, algumas especificidades deveriam ser consideradas. A primeira consideração que o autor faz é a de que os domínios da política, no caso brasileiro, tendem a ser mais centrados nos órgãos estatais. Isso ocorreria, segundo a observação, porque "organizações estatais tendem ao mesmo tempo a ser pouco institucionalizadas, assim como a apresentar baixo insulamento e intensos processos de migração entre órgãos e com o setor privado"; a segunda consideração circunscreve que a unidade básica das relações (e da ação) são os indivíduos e não as organizações. Isso se dá porque "a importância das relações pessoais e a baixa institucionalização de inúmeros procedimentos no funcionamento da administração pública do Brasil, quando comparado com os países centrais, tornaria artificial e potencialmente enganosa uma análise baseada nas organizações” (MARQUES, 2006, p. 21).

$\mathrm{O}$ autor apregoa que as pesquisas empreendidas sobre políticas públicas avançarão se o esforço para a sua compreensão conseguir observar os atores envolvidos em "contextos institucionais e relacionais, ou associar as estruturas de poder aos contextos institucionais em suas estruturas relacionais" (MARQUES, 2006, p. 17). Esse tipo de análise propõe a existência de "estruturas de médio alcance constituídas por redes entre atores no interior de instituições específicas. Essas estruturas constituem um denso e complexo tecido relacional interno ao Estado que emoldura a dinâmica política e influencia fortemente a formulação e a implantação das políticas públicas" (MARQUES, 2006, p. 15). 
As posições dos atores e relações estabelecidas nas redes constituem estruturas relacionais que definem escolhas, possibilitam o acesso a instrumentos de poder, evidenciam prováveis conflitos e alianças e influenciam os resultados da política. No entanto, os canais pelos quais se efetivaria tal influência seriam estabelecidos em relações entre organizações.

Para essa concepção, os atores, em cada situação social, são dotados de instrumentos de poder "que disputam os resultados do processo político em termos da distribuição de benefícios escassos, assim como de poder político, que em última análise explica a possibilidade diferenciada de captura daqueles benefícios" (MARQUES, 2006, p. 17). Considera também que estrutura de poder seria esse "conjunto articulado de atores, posições relativas de poder e instrumentos para exercê-lo" (MARQUES, 2006, p. 18).

Marques defende que a análise empreendida a partir das formações das redes sociais contribuiu de diversas maneiras para o entendimento das políticas. Considera como contribuição a compreensão de que:

[...] os efeitos da complexa interdependência presente na produção de políticas sobre a ação social, considerando não apenas as ligações em torno dos atores (ou as suas interações individuais), mas também a estrutura dos vínculos e os padrões gerais em que esses estão inseridos. Tais elementos exercem fortes efeitos sobre a ação individual e estratégica, influenciando a maneira pela qual a racionalidade é limitada. Em sentido mais geral, o uso das redes permitiu a incorporação do contexto em que se dá o desenvolvimento de uma determinada política, levando à produção de interpretações mais sociológicas do comportamento dos atores. (MARQUES, 2006, p. 20).

Pela abordagem das redes entre pessoas e organizações que estruturam internamente as organizações estatais, o autor identifica o que denominou de tecido do Estado:

No funcionamento concreto da política (e das políticas), os contatos institucionais são canalizados por contatos pessoais e institucionais que se apóiam em padrões de relações preexistentes, assim como ajudam a recriálos. Essas estruturas de médio alcance canalizam informações, apoios, alianças e a formação de projetos, visões e percepções. Além disso, esses 
padrões de relação induzem visões de mundo (e da política), influenciam a formação de preferências, constrangem escolhas, estratégias e alianças e alteram resultados políticos. Em termos mais concretos, podemos dizer que o tecido do Estado é composto por uma superposição de redes de relações temáticas que circunscrevem as comunidades ligadas a cada uma de suas ações. Essas redes incluem os diversos atores envolvidos com uma determinada política, como técnicas do Estado, ou burocracias em um sentido mais geral, demandantes da política, contratantes da política e políticos e gestores que ocupam cargos eletivos e de livre indicação. (MARQUES, 2006, p. 22).

A maneira como foram levantados os dados para o estudo da elaboração do programa Educom.rádio e o exame de sua relação com a sua continuidade talvez não sejam suficientes para uma completa aplicação da análise conferida à formação de redes (como Marques a define), com todas possibilidades de aferição em um estudo de caso restrito a órgão de um setor do governo municipal. Sobretudo, a respeito da estrutura de vínculos e os padrões gerais em que estão inseridos os efeitos da complexa interdependência presente na produção de políticas sobre a ação social. Mas, a maneira que empregamos para obter dados e confrontálos com a continuidade do caso do programa aqui estudado sugere preocupações analíticas importantes, que levam a corroborar algumas atenções que foram pretendidas para o entendimento e exame de fatores que causam impacto em políticas. Ainda que não se tenha evidenciado, necessariamente, uma rede, reuniram-se indícios de vínculos entre atores que por ventura pudessem ser considerados como nós de uma treliça, desde que se tenha em vista identificar a complexidade da manifestação de uma rede social em funcionamento, cujos pormenores são apenas esboçados aqui. Assim, aquém do uso desse método, esta pesquisa se contenta em entender parte do problema proposto, que se constitui como desafio crucial para a análise de políticas.

Viana (1996), com o objetivo de construir modelos explicativos para as diferentes fases ou etapas das políticas públicas, estudou uma série de autores procurando apreender a relação que se estabelece entre atores governamentais e entre estes e atores não-governamentais no 
processo de fazer política. Para escolher os autores estudados, ela afirma que o critério foi identificar aqueles que analisaram as condições de formação e desenvolvimento de cada uma das fases das políticas públicas: construção da agenda, formulação de políticas, implementação e avaliação.

Para os fins pretendidos nesta parte do presente trabalho, importa mais o momento em que aquela autora define a formulação de políticas (que, aqui, é denominada elaboração de políticas). Aquela autora define a ocorrência da elaboração da política como sendo um “espaço político de trocas e indeterminações, conflitos e poder". Essa fase pode ser ainda desmembrada em três subfases: primeira, quando uma massa de dados transforma-se em informações relevantes; segunda, quando valores, ideais, princípios e ideologias se combinam com informações factuais para produzir conhecimento sobre ação orientada; e última, quando o conhecimento empírico e normativo é transformado em ações públicas, aqui e agora (VIANA, 1996, p. 13).

Esta pesquisa se afeiçoa à definição proposta por Viana, mas, aplica ênfase em entender a forma de elaboração a partir da participação na elaboração, procurando distinguir os atores e grupos envolvidos nessa fase e, sendo assim, pretendeu-se examinar também com a descrição da elaboração do programa Educom.rádio, que se segue, quais foram as situações e escolhas que propiciaram uma massa de dados transformar-se em informações relevantes para a constituição do programa; bem como observar princípios e ideologias que se combinaram com informações factuais para produzir conhecimento sobre a ação orientada para a elaboração; e quando o conhecimento empírico e normativo foi transformado em ações públicas.

Dessas visões acerca dos modelos para análise de políticas, programas ou projetos, aponta-se para a necessidade de: examinar a relação que se estabelece entre atores nos processos de 
fazer política; observar os atores envolvidos em contextos institucionais e relacionais, ou associar as estruturas de poder aos contextos institucionais em suas estruturas relacionais; bem como observar a formação de grupos com interesses comuns. Na descrição que se segue, procura-se realizar a maior parte dos procedimentos metodológicos comentados até aqui. 


\section{A VIOLÊNCIA NA AGENDA PÚBLICA}

Esta parte foi pensada com a finalidade de indicar como a ocorrência de violência em ambientes escolares foi se estabelecendo como agenda política e teve como resultado ações governamentais, dentre as quais, o programa Educom.rádio. No entanto, não se pretende justificar ou avaliar se determinados programas, projetos ou políticas serviram ou não à finalidade a que se propunham (a combater a violência, por exemplo).

A entrada do tema violência em ambiente escolar ${ }^{6}$ na agenda de preocupações políticas, no Brasil, remonta à década de 1980 . O aumento da violência notado naquela época teria a ver com as mudanças sociais ocorridas com o fim da ditadura militar: "Sem realmente poder contar com instituições novas em terreno sensível, e já não mais dispondo dos mecanismos de regulação característicos do período autoritário, a democracia terminou abrindo amplas possibilidades para que a violência se desenvolvesse" (PERALVA, 2000, p. 20). Outros estudos observam que, naquele período, ocorreu também o aumento do crime violento, assim como o aumento do medo do crime (CALDEIRA, 2000, p. 27). Ainda que haja a ressalva de que a violência em ambiente escolar não reflita necessariamente a violência em seu entorno, ou seja, no meio social em que as escolas estão envolvidas, muitos autores concordam que foi a partir do momento da redemocratização e concomitantemente em todos os espaços que o tema da violência começou a ganhar a intensificação e freqüência necessárias para tomar o debate público.

Em São Paulo, especificamente, ocorre que os elevados índices de violência em bairros periféricos coincidem também com a manifestação da violência envolvendo escolas (GONÇALVES; SPOSITO, 2002).

\footnotetext{
${ }^{6}$ Para melhor comentário sobre os termos referentes ao debate envolvendo violências e escolas, ver DEBARBIEUX, 2002, p. 61
} 
Caldeira (2000, p. 101), ao estudar o fenômeno da violência em São Paulo, afirma que o aumento observado é resultado de um ciclo complexo que envolve diversos fatores. Esse ciclo estaria relacionado ao padrão violento de ação da polícia; descrença no sistema judiciário como mediador público e legítimo de conflitos e provedor de justa reparação; respostas violentas e privadas ao crime; resistência à democratização; a débil percepção de direitos individuais e o apoio a formas violentas de punição por parte da população.

Em outro estudo sobre o fenômeno, Waiselfisz e Maciel (2003, p. 12) concluíram que, entre os jovens, a violência também encontra ressonância na apatia, na falta de projeto de futuro, na ausência de perspectivas, na quebra dos valores de tolerância e solidariedade, "aspectos que fazem parte da crise de significações de nossa modernidade". Essa crise levaria a uma situação de asfixia, onde jovens não vêem saída para solucionar problemas, nem mecanismos de articulação (movimentos políticos, sociais ou culturais) que funcionem como integradores. Os impasses impostos à sociedade geram diversas formas de culto à violência como alternativa de combate aos problemas imediatos.

Gonçalves e Sposito (2002, p. 102) chamam a atenção para dois aspectos que devem ser levados em consideração quando se tem por intuito traçar os elementos principais que orientam o nascimento de políticas para a superação da violência: o primeiro, reafirmando o que os autores citados anteriormente concluíram, diz respeito ao fato de que o tema da violência na sociedade brasileira ganha o debate público com o processo de democratização (período que muitos autores tratam com a denominação de redemocratização, ou seja, o processo iniciado em 1979, com a revogação do Ato Institucional número 5, que culminou com fim da ditadura militar, em 1985); e segundo, o fato de que a violência em meio escolar no Brasil tanto decorre da situação de violência social que atinge a vida dos estabelecimentos, sobretudo públicos, como pode expressar modalidades de ação que nascem no ambiente pedagógico, neste caso, a violência escolar. 
Umas das primeiras iniciativas do Poder Público a respeito do entendimento do fenômeno da violência envolvendo escolas como problema público e a busca por formas de encaminhar soluções para o seu enfrentamento foi suscitada em meados da década de oitenta, pela Secretaria Municipal de Educação de São Paulo (governo Mário Covas, 1983-1985). O projeto era denominado Fim de semana. Esse projeto incentivava a abertura das escolas nos fins de semana para atividades que envolvessem tanto a comunidade escolar (estudantes, docentes, funcionários) quanto os moradores de seu entorno. No entanto, "o incentivo da participação de diferentes atores sociais rapidamente se esvanece, ainda dentro da década de 80, nas administrações seguintes" (GONÇALVES; SPOSITO, 2002, p. 112).

Comentando a criação de programas públicos destinados especificamente a procurar soluções que pudessem vir a contribuir para a redução da violência em escolas, Gonçalves e Sposito afirmam que, durante a década de 1990, não se observaram grandes avanços. No entanto, informam que a administração Luiza Erundina (1989-1992) lançou o projeto Pela Vida, Não à Violência. E que os indícios que justificavam tal projeto seriam observados em dados coletados pela Secretaria Municipal de Educação. Esses dados indicavam certa alteração no padrão de episódios ligados à violência em meio escolar na cidade de São Paulo. Essa alteração no padrão seria evidenciada pelo fato de que, na década de 1980, registraram-se depredações e invasões em períodos ociosos como os principais problemas, e que, no início dos anos 1990, as práticas de violência contra a pessoa atingiam quase $62 \%$ das ocorrências em escolas municipais, e aquelas contra o patrimônio, 38\% (GONÇALVES; SPOSITO, 2002, p. 144).

Em 11 de junho de 1992, foi instituído, por meio da portaria 7.372, o projeto Pela Vida, Não à Violência. Como justificativa para sua constituição, considerou-se "a necessidade de viabilizar a rigorosa observância da Lei Federal 8.069/90 (Estatuto da Criança e do Adolescente) no âmbito da Secretaria Municipal de Educação" (SÃO PAULO, 1992, p. 29). 
Na apresentação do projeto, pode-se ler uma de suas preocupações:

Procuramos evoluir, de uma noção idílica, indiferente, impotente e "neutra" da Escola em relação à violência, para a clareza, embora incômoda, de que escola não tem somente lousa e giz. Tem discriminação, tem agressão, tem opressão, tem violência e expulsão, tratada genérica e eufemisticamente por "evasão". E é dramático constatar, pela voz dos próprios agentes, o quão melancólico é o papel desempenhado pela escola na agonia destes seres humanos. (SÃO PAULO, 1992, p. 7).

O Pela Vida, Não à Violência manifestava que não tinha como objetivo básico combater a violência e justificava essa posição definindo-a da seguinte maneira:

Temos clareza política de que a violência é, mais que o reflexo de uma sociedade iníqua, excludente e discriminatória, uma necessidade das elites para a reprodução do sistema que as mantém enquanto tal. Não há dominação sem força e não há força que não resulte em dominação. A violência das depredações e agressões é o resultado óbvio da existência vilipendiada a que foram condenadas imensas parcelas da população brasileira pela ação, esta sim predadora, de elites, há quase quinhentos anos. Levantar muros, reforçar vigilância ou providenciar policiamento, não elimina o problema da violência. (SÃO PAULO, 1992. p. 7).

A observação desse tipo de definição remete à preocupação de o projeto debater, antes, a convicção de que "com mais polícia há mais segurança e menos violência" (com a intenção de combater essa forma de atuação), presente na maior parte de ofícios e memorandos encaminhados ao grupo do projeto requerendo a presença de policiamento nas escolas. $\mathrm{O}$ projeto esperava também que se percebesse que a pedra angular no processo de violências era alimentada pelo comportamento alarmista, segregador, seletivo, punitivo e policialesco de determinadas escolas em relação a seus próprios alunos e ex-alunos. (SÃO PAULO, 1992. p.8).

Esse projeto apontava como procedimentos básicos:

- Ouvir todos os seguimentos envolvidos em queixas, em especial o aluno.

- $\quad$ Explicitar as contradições existentes.

- Trabalhar contradições internas. 
- Trabalhar relações humanas.

- Organizar comissões que aprofundem as discussões sobre violência, suas causas e sobre a segurança possível.

- $\quad$ Abrir as escolas para dentro e para fora. Fazer funcionar efetivamente as estruturas democráticas das escolas. (SÃO PAULO, 1992. p. 24).

As atividades desenvolvidas pelo projeto foram de caráter variado, respondiam à necessidade que as escolas apresentavam. Em 1992, a Secretaria de Educação do município de São Paulo dividia a capital em 10 Núcleos de Ação Educativa (NAEs). As escolas recorriam a esses núcleos para manifestar suas demandas que pudessem ser tratadas a partir dos objetivos do projeto. De acordo com o exame dessas demandas, apresentava-se uma forma específica de atuação para cada escola. Alguns exemplos foram: desenvolvimento de mutirão para a conservação das escolas; conscientização sobre o uso das escolas para os mais diversos fins; mobilizações nas comunidades; debates os mais variados sobre violências. $\mathrm{O}$ exame das demandas das escolas era realizado por uma equipe do projeto, composta por 5 pessoas da coordenação, mais uma de cada NAE (ou seja, mais 10 pessoas) e mais uma parte denominada Equipe de Apoio, composta por 6 pessoas. (SÃO PAULO, 1992, p. 11).

Dentre as pessoas que compunham a Equipe de Apoio do projeto Pela Vida, Não à Violência, estava a professora Dirce Gomes, representante, à época, do Gabinete da Conae (Coordenadoria dos Núcleos de Ação Educativa), em 1992.

Gomes (2007) narra os acontecimentos e preocupações que levaram à criação do projeto Pela Vida, Não à Violência da seguinte forma:

Na administração primeira do PT [1989-1992], em São Paulo, da Luiza Erundina, eu trabalhei com o professor Paulo Freire no gabinete dele, na [Secretaria Municipal de] Educação. Dessa nossa relação (a minha experiência era toda da rede estadual que estava indo para uma administração municipal), e havia um espanto muito grande do professor Paulo Freire com a quantidade de queixas que chegava às segundas-feiras em relação à violência nas escolas: depredação ao prédio, outras queixas de violências, em relação ao autoritarismo do diretor. Então, havia, assim, uma incidência muito grande sobre violência e o professor [Paulo Freire] pensou 
em uma forma de nós fazermos um projeto que discutisse as questões de violência na escola, de uma forma multidisciplinar e não fosse só um assunto de pedagogo, que tivesse envolvido pedagogo, assistente social, psicólogo e um criminalista, porque o limite entre a criminalidade e a marginalidade, quer dizer, quando o aluno deixa de ser um marginal e passa a ser um criminoso, esse limite é muito tênue e muito confuso nas administrações das escolas. Por essa via, nós criamos um projeto que se chamou Pela Vida, Não à Violência, onde, junto ao Gabinete do Secretário, que então era o Paulo Freire, criou-se uma equipe multidisciplinar, que pensou uma atuação junto aos NAEs. Pensando que o NAE é o que está mais próximo da escola e qualquer manifestação de violência ou situação difícil na escola, ela tem de ser primeiramente atendida pelo NAE e só então chegar ao nível central. Porque ele, como Secretário, recebia ofícios semanais registrando essas ocorrências. Então, pensamos o projeto em que pudéssemos preparar as equipes dos NAEs para tratarem as questões de violência nas escolas vistas de diversos ângulos. Nenhuma faculdade prepara o professor para enfrentar a violência que ele vinha enfrentando na ocasião. A gestão 89-92 era muito mais afeita a questões disciplinares na escola: autoritarismo dos professores e diretores, exigências absurdas, aluno que não tinha representação, não tinha voz, as violências eram muito mais voltadas para isso e uso indevido do prédio no fim de semana. Ou para drogas ou simplesmente ocuparem os equipamentos esportivos. Em muitas regiões, o único equipamento esportivo era o da escola, não havia outro. Então, se a escola não abria, os moradores invadiam. (Informação pessoal) ${ }^{7}$.

Com o fim do governo petista de Luiza Erundina, em 1992, esse projeto não obteve continuidade nos governos que se seguiram no Município de São Paulo.

No entanto, em nível federal, a iniciativa de induzir políticas de redução da violência em meio escolar prosseguiu, partindo do Ministério da Justiça. Esse ministério determinou iniciativas que foram desdobradas em nível estadual e municipal. Em junho de 1999, incumbiu-se uma comissão de especialistas de elaborar diretrizes para enfrentar a violência nas escolas, contando com a parceria de alguns institutos de pesquisa e algumas organizações não governamentais (GONÇALVES; SPOSITO, 2002, p. 106). Como primeiro resultado dos trabalhos dessa parceria, houve a elaboração do Programa Paz nas Escolas, desenvolvido a partir de 2000, considerado como programa estratégico do setor Justiça e Segurança do programa do governo federal denominado Avança Brasil. O Programa Paz nas Escolas

\footnotetext{
${ }^{7}$ GOMES, D. Entrevista concedida a Mauro Soares Cordeiro em 19 de dez. 2007. Para a apreciação do perfil dos entrevistados, ver o Apêndice ao final deste trabalho.
} 
previa como principais ações: cursos de formação para educadores e policiais para lidar com o tema de violência nas escolas; apoio às organizações de jovens no fortalecimento de grêmios estudantis; capacitação de policiais para enfrentamento da violência nas escolas. (BRASIL, 2008a).

Em 2000, a Organização das Nações Unidas propõe uma série de mobilizações para compor o que viria a ser denominado como o Ano Internacional da Cultura de Paz. A Unesco, subsidiária dessa proposta, e já demonstrando preocupação com o tema da violência, uma vez que vinha realizando pesquisas desde 1988 com vista ao entendimento desse fenômeno, desenvolve o Programa Abrindo Escolas: Educação e Cultura para a Paz, o qual: "Se propõe a abertura de espaços públicos, sobretudo das unidades escolares, de modo a oferecer alternativas de esporte, cultura e lazer aos jovens, como um contraponto à violência" (WAISELFISZ; MACIEL, 2003, p. 9).

Esse programa começou a ser implantado naquele ano 2000, em 111 escolas do Estado do Rio de Janeiro e em 30 de Pernambuco. Sucintamente, o programa se propunha a abrir as escolas públicas nos fins de semana, em áreas de concentração de população de baixa renda, para a prática de esporte, cultura e lazer. (WAISELFISZ; MACIEL, 2003, p. 30).

Em 2000, para concorrer ao Executivo municipal de São Paulo, foi lançado o Programa de Governo da candidata Marta Suplicy para o período de 2001-2004. No item Propostas, onde são anunciadas as ações pretendidas e denominadas como Políticas Sociais, o programa nomeia com o título Educação: prioridade urgente o que seria priorizado no setor da Educação, caso vencesse as eleições. Como diretriz para o setor, o programa orienta que será retomada uma proposta que tenha a gestão democrática da escola como uma preocupação central. Afirma também o desejo da democratização do acesso e permanência e ainda a democratização do conhecimento. Na parte em que apresenta os propósitos para alcançar o 
que foi denominado como Escola é um direito de todos, pode-se ler como uma das ações a “implementação de projetos especiais: Projeto de Orientação Sexual, Projeto pela Vida, Não à Violência, Educação no Trânsito, RAP...Pensando a Educação e outros" (COLIGAÇÃO MUDA SÃO PAULO PT, PC do B, PCB, PHS, 2000, p. 22, grifo nosso).

Em 2001, ao vencer a eleição municipal realizada em 2000, o Partido dos Trabalhadores volta ao governo do Executivo municipal de São Paulo sob o comando da prefeita Marta Suplicy. Para o cargo de Secretário Municipal de Educação, foi nomeado o professor Fernando de Almeida, que, até aquele ano, dirigia a Escola Nossa Senhora das Graças, "coordenando a área pedagógica da escola, dando aulas para o ensino médio até a véspera de assumir a Secretaria". Era também docente em programa de pós-graduação, na Pontifícia Universidade Católica de São Paulo (PUC-SP), "trabalhando na área de novas tecnologias".

Para ocupar o cargo de chefe de gabinete do Secretário Municipal de Educação, foi nomeada a professora Selma Rocha. Rocha conhecia Dirce Gomes de outras experiências em ações desenvolvidas pelo Partido dos Trabalhadores em Santo André e a convidou para compor a coordenação do Projeto Vida na Secretaria Municipal de Educação de São Paulo.

Gomes desenvolvia o Projeto Vida em Santo André e aceitou assumir a coordenação do projeto especial, diretamente ligado ao Gabinete do Secretário Municipal de Educação em São Paulo, denominado também Projeto Vida. A concepção e o nome desse projeto remetem ao projeto para tratar da violência em ambiente escolar no primeiro governo petista do município de São Paulo, o projeto Pela Vida, Não à Violência. Gomes (2007) atesta esse fato da seguinte maneira:

Com o retorno do PT, com a gestão da Marta, nós fomos convidados a retomar esse projeto porque as questões de violência na escola já tomavam outras proporções. Esse projeto, decorrido esse tempo todo [1992-2001], teve de ter outras preocupações. Uma delas era a aproximação com a comunidade, da abertura das escolas para a comunidade e toda a questão 
com a comunicação. Então, passa a ter outro nome, passa a ser o Projeto Vida, do qual eu era a coordenadora. Era um projeto ligado diretamente ao Secretário, não era ligado nem à parte administrativa, nem à pedagógica. Ele tinha esse caráter multidisciplinar e ele dependia de algumas intervenções que precisavam estar na decisão direta do Secretário. Por exemplo, apareceu um defunto na escola, houve um assassinato, houve um roubo ou uma outra coisa mais grave, que você precisasse a interferência de polícia, ou civil ou militar, não dava para você fazer essas ações, essas decisões, sem o contato direto com o Secretário. Então, continua a ser um projeto ligado ao Secretário. De início não havia nenhum recurso previsto para as ações desse projeto. (Informação pessoal) ${ }^{8}$.

Em entrevista realizada nesta pesquisa, comentando o surgimento do Projeto Vida, o

Secretário Fernando de Almeida (2008) diz que:

Foi elaborado no meu gabinete, basicamente com a professora Selma Rocha, que era minha chefe de gabinete, e já conhecia a professora Dirce e a professora Sonia há muitos anos, e tinha tido uma experiência com elas, se não me engano, na prefeitura de Santo André, muito favorável. A idéia basicamente era enfrentar a violência, a questão das drogas, a questão da agregação familiar, agregação da relação escola-comunidade, de uma maneira propositiva, ou seja, uma coisa que só o nome já indica a direção, de forma que é o Projeto Vida: vamos discutir a vida. Discutir a vida através das artes, através dos setores de comunicação... E, claro, pela discussão sobre a vida, você entra naquilo que é contra a vida, aquilo que desagrega, aquilo que dissolve as relações vitais das pessoas, que são as drogas... Horrendas... Desde a relação com a Guarda Municipal até a participação das escolas no fim de semana, que tinham programas de valorização da vida, usar a escola para isso também. Então, foi por isso que tive contato com [o projeto], e nasceu pessoalmente no meu gabinete.

[...]

Nós criamos o setor [o Projeto Vida], não existia o setor específico para discutir a questão da violência, drogas... A gente criou esse esquema chamando a Sônia e a Dirce. (Informação pessoal) ${ }^{9}$.

A principal diretriz também não mudou no novo projeto, já que o Projeto Vida teve como meta o cumprimento da lei que dispõe sobre o Estatuto da Criança e do Adolescente (ECA), “especialmente em seu artigo 5" (SÃO PAULO, [2004], p. 2). Esse artigo prescreve que "nenhuma criança ou adolescente será objeto de qualquer forma de negligência, discriminação, exploração, violência, crueldade e opressão, punindo na forma de lei qualquer

\footnotetext{
${ }^{8}$ GOMES, D. Entrevista concedida a Mauro Soares Cordeiro em 19 de dez. 2007.

${ }^{9}$ ALMEIDA, F. Entrevista concedida a Mauro Soares Cordeiro em 28 de mar. 2008.
} 
atentado, por ação ou omissão, aos seus direitos fundamentais" (SÃO PAULO (CIDADE), 2000, p. 34).

O Projeto anuncia ainda que a "questão da violência será trabalhada dentro do eixo da democratização da gestão da escola e do sistema, da compreensão da realidade social e econômica do país no currículo, na construção coletiva do conhecimento e na qualidade social da Educação" (SÃO PAULO, [2003], p. 5).

Para desenvolver ações que permitissem o cumprimento dessa diretriz, o Projeto previa auxiliar "professores, funcionários, pais e alunos a situar o problema da violência dentro de sua esfera de complexidade”. Isso significava os seguintes objetivos declarados:

- $\quad$ Entender suas causas;

- Precisar os limites da atuação profissional;

- Exercitar formas não violentas de resolver conflitos;

- Saber reconhecer sinais de violência contra os alunos e tomar providências previstas no Estatuto da Criança e do Adolescente ;

- $\quad$ Fazer funcionar as estruturas democráticas;

- Atuar rigorosamente dentro dos princípios éticos.

O Projeto Vida surgiu vinculado ao Gabinete do Secretário Municipal de Educação de São Paulo. Foi constituído como uma das primeiras ações da Secretaria destinada à prevenção da violência nas escolas. Teve também a intenção de conferir execução à lei municipal nº 13.096 (Programa de Prevenção da Violência nas Escolas - resultado da aprovação do projeto de lei apresentado pelo vereador Carlos Neder), de 8 de dezembro de 2000, regulamentada pelo decreto $\mathrm{n}^{\mathrm{o}}$ 42.438, de 26 de setembro de 2002, assinado pela prefeita Marta Suplicy, destinando-se a auxiliar "professores, funcionários, pais e alunos a situar o problema da violência dentro de sua esfera de complexidade" (SÃO PAULO, [2004], p. 2). 
Dentre os projetos especiais desenvolvidos pelo Projeto Vida para viabilizar seus objetivos, houve a implementação do programa Educom.rádio, do projeto Escola Aberta e algumas iniciativas relacionadas às questões de gênero e étnico-raciais.

O Escola Aberta visava a utilização das escolas durante os fins de semana, feriados, recessos e férias para a realização de atividades culturais, esportivas e de lazer, assim como atividades programadas pelas escolas e que correspondiam "aos anseios da comunidade escolar". As escolas participavam desse projeto por adesão (SÃO PAULO, [2003], p. 7).

O programa Educom.rádio é anunciado pelo documento como sendo "um importante programa de política pública em Educação". E afirma ainda que:

Com a instalação de estúdio de rádio nas escolas, o projeto auxilia o jovem a construir seu conhecimento interagindo num novo espaço, por meio de práticas pedagógicas inovadoras. Os resultados interferem, positivamente, na comunicação entre professor e aluno, estreitando os vínculos do grupo, oportunizando a reflexão, a discussão e criando soluções para os problemas da comunidade escolar e a sociedade. (SÃO PAULO, [2003], p. 8).

A criação de um projeto especial como foi o Projeto Vida, vinculado diretamente ao Gabinete do Secretário Municipal de Educação de São Paulo para agenciar outros projetos, programas e ações, também considerados especiais, parece ser o reconhecimento de que tal problema a ser enfrentado deveria ter um lugar prioritário na atenção do poder público. Parece se configurar também como evidência para a constatação de Fuks (2000, p. 80), que observa que: “[...] a emergência de questões na agenda pública explica-se mais em termos da dinâmica social e política do que dos atributos intrínsecos dos assuntos em disputa, ou seja, das 'condições reais' dos problemas em questão". 


\section{A ELABORAÇÃO DO PROGRAMA EDUCOM.RÁDIO}

Para caracterizar a forma de elaboração do programa Educom.rádio quanto ao número e variedade de indivíduos e grupos participantes, objetivo específico 1 do projeto desta pesquisa, foram realizadas entrevistas com dois responsáveis pelos principais cargos no nível hierárquico superior de administração pública do setor educacional municipal (o Secretário Municipal de Educação entre 2001-2002 e a coordenadora do Projeto Vida) e dois profissionais do NCE.

O programa Educom.rádio tem sua gênese ligada a um projeto que a professora da rede municipal de educação pública de São Paulo, Fátima Mohamed Younis, fez enquanto trabalhava no NAE 8 como assistente técnica educacional, no início de 2001. Esse projeto foi elaborado para ser implementado em uma escola municipal de ensino fundamental sob responsabilidade daquele NAE, com o apoio de seu coordenador Matias Vieira. O projeto foi suscitado também com vistas a outra finalidade: como parte das exigências do Curso de Especialização Lato Sensu Gestão da Comunicação oferecido na ECA-USP, no qual a professora Younis havia se matriculado.

Em março de 2001, Younis apresentou à direção da Escola Municipal de Ensino Fundamental Benedito de Jesus Batista Laurindo, por meio da coordenação do NAE 8, o projeto Gestão da comunicação, via rádio, em escola numa situação de conflito, com nove objetivos a serem atingidos, todos em função do uso de rádio para comunicação intra-escolar, esperando que:

[...] os resultados reflitam na melhoria da qualidade de ensino através da formação contínua abordando temas atualizados, proporcionando aos educandos o desenvolvimento de competências e habilidades básicas e sua integração em nossa sociedade. Através de trocas compartilhadas em momentos que venham a sanar os problemas e dificuldades de aprendizagem que estão presentes na prática em sala de aula. A comunidade escolar e local se unem para buscar soluções para a violência instaurada no local. (PROJETO ESPECIAL DE AÇÃO, 2001, p. 2). 
O assistente de diretor da escola, Angel Serafino, chancelou esse projeto proposto para ser executado naquela escola em 21 de março de 2001: estava aberta a possibilidade de realização de um projeto que previa a utilização da linguagem radiofônica sob algumas justificativas, dentre as quais, unir pessoas para buscar soluções para a violência material e simbólica vivida por aquela escola. Todo esse empenho de Younis parece se caracterizar como um exemplo de inovação educacional definida por Ghanem (2006, p. 398) “como práticas caracterizadas pelo isolamento, pela fragmentação, pela descontinuidade no tempo, pela baixa visibilidade e pelo forte voluntarismo das pessoas que são suas agentes".

Para estipular como seria utilizada a linguagem radiofônica anunciada no projeto, Younis contou com a contribuição das estudantes de mestrado do Programa de Pós-Graduação em Ciências da Comunicação da ECA-USP, Grácia Maria Lopes Lima e Patrícia Horta Alves. O professor daquela Escola, Ismar de Oliveira Soares, que orientava essas estudantes no mestrado, dá indícios do início da elaboração do projeto de Younis:

O germe do programa foi uma palestra que eu dei no início de 2001 [...]. E participando dessa palestra estava uma professora chamada Fátima, professora da rede. Era professora de arte na prefeitura e estava lá e ela tinha interesse em fazer o curso de Gestão [da Comunicação] da ECA. E para entrar no curso precisa ter um projeto. Ela veio e me apresentou um projeto, que era combate à violência em uma das escolas, Emef Padre Batista, que havia sido depredada e havia conflito entre os alunos e professores, e ela veio. E, na conversa, notei que ela tinha alguma dificuldade de domínio da língua portuguesa, ela fala com sotaque espanhol... Como o curso é muito exigente na parte de formulação de projetos, eu a aproximei de duas orientandas minhas, que eram a Grácia e a Patrícia, para que, juntas, pudessem desenvolver uma proposta. (Informação pessoal) ${ }^{10}$.

Lima (2008) comenta também esse momento dizendo que:

Ela [Younis] procura o professor Ismar com uma grande inquietação: que era buscar uma alternativa educacional, ou educomunicativa, melhor dizendo, que servisse para diminuir a violência nessa escola onde ela atuava. A

\footnotetext{
${ }^{10}$ SOARES, I. Entrevista concedida a Mauro Soares Cordeiro em 26 de ago. 2008.
} 
solicitação vem por ela mesma. Lembro exatamente da cena: estávamos ali, na frente da faculdade, e estávamos passando eu e Patrícia Horta, na época, orientandas do professor Ismar. Tanto eu quanto Patrícia éramos orientandas no mestrado sob orientação do professor Ismar. Aí, ele chama as duas que estavam de passagem e diz: "Olha, ouçam, acompanhem a conversa". E a professora Fátima repete novamente: "O que fazer com uma escola com um nível de violência tão grande?". Na época, naquele momento, a Patrícia falou, entre risos: "Vamos fazer rádio!". Aí, o professor Ismar, com aquele jeito dele, olhou e falou: "Olhem de perto essas coisas". E aí a gente passou por um período de contato muito direto: eu, Patrícia e professor Ismar. Mais afastada um pouco, mas, acompanhando, a Fátima. E ela nos trouxe muito material: fotos do prédio que havia sido depredado; fotos de fases anteriores ao momento que ela estava ali. Ela trouxe a memória da violência registrada no patrimônio e nas ações dos alunos, dos funcionários... Especialmente alunos. Usando as palavras da Patrícia ainda: "A Grácia faz rádio..." Porque na época eu estava... No ano 2000 (de 1995 a 2000), nós estávamos no sexto ano de experiência do projeto Cala-boca já morreu. É um projeto que nasce em 95, aqui na região oeste, especificamente no Jaguaré, com a intenção de vivenciar um processo de educação não formal que garantisse a formação de sujeitos autônomos, criativos e que gostassem do aprender. (Informação pessoal $)^{11}$.

A opção pela utilização da linguagem radiofônica, portanto, entra no projeto de Younis por sugestão de Lima, que já contava com a experiência realizada como coordenadora da Gens, empresa que presta serviços educacionais e desenvolve o projeto Cala-boca já morreu. Lima afirma ainda que a Gens também havia sido convidada para desenvolver um projeto junto à Secretaria Municipal de Educação de Vargem Grande Paulista:

Quando o professor Ismar nos chama para compor a idealização do projeto, não teria outra forma de contribuir senão levando a minha experiência. Por conta do Gens, que é a assessoria que durante nove anos mantém o Calaboca já morreu como uma ação não-lucrativa, que já tinha sido chamada para desenvolver um projeto de rádio em Vargem Grande Paulista. Em 2000, a Secretária Neide Cândido Braz, Secretária de Educação de Vargem Grande Paulista, chamou a gente para implantar nas escolas dela, que eram cinco. Ela tinha cinco escolas municipalizadas. Ela disse: "Vocês fazem isso com o Cala-boca já morreu, não querem fazer com a escola pública?". Aí, quando eu entro no Educom já estou implantando em Vargem Grande. No modelinho do Educom. (Informação pessoal) ${ }^{12}$.

\footnotetext{
${ }^{11}$ LIMA, G. Entrevista concedida a Mauro Soares Cordeiro em 14 de jul. 2008.

${ }^{12}$ Ibid.
} 
Essa experiência adquirida por Lima foi determinante para a participação na elaboração do programa Educom.rádio. Comentaremos essa participação mais adiante.

Em paralelo à apresentação do projeto para a direção da Emef Benedito de Jesus Batista Laurindo, com o apoio do NCE, Younis apresenta seu projeto para ser analisado também pelo Projeto Vida. Essa relação entre Younis e o NCE vinha do fato de que Soares, coordenador daquele núcleo, é também professor do Curso de Especialização Lato Sensu Gestão da Comunicação, do qual Younis foi estudante e teve o seu projeto aprovado como parte de plano de trabalho apresentado como requisito do curso. O parecer da equipe técnica emitido pelo Projeto Vida foi favorável ao projeto de Younis, porém, o motivo alegado para não o viabilizar naquele momento foi ser "inviável a administração pública financiar um trabalho acadêmico beneficiando um funcionário que teria uma unidade escolar como objeto" (SÃO PAULO, 2002, p. 1).

Embora tenha havido a negação ao projeto de Younis, a partir desse momento, o contato estava estabelecido, o que daria azo à configuração de um programa, ou seja, uma iniciativa com muito maior amplitude. Assim, abriu-se um "canal de acesso", o qual permitiria ao grupo entrar em contato com as elites políticas que tomam as decisões que lhe interessam (SCHWARTZENBERG, 1979, p. 656). A coordenadora do Projeto Vida mostrou-se interessada pela proposta. O projeto de Younis era uma tentativa de buscar soluções para o problema da violência material e simbólica em uma escola. O Projeto Vida surgiu em 2001 com a justificativa declarada de conferir cumprimento à Lei $\mathrm{n}^{\circ} 13.096$ de 8 de dezembro de 2000, regulamentada pelo Decreto $\mathrm{n}^{\mathrm{o}} 42.438$ de 26 de setembro de 2002, que instituiu o Programa de Prevenção da Violência nas Escolas. Seu objetivo era desenvolver ações que viessem a prevenir a violência nas escolas. O projeto de Younis ainda não contava com financiamento e, para ter o Projeto Vida como fonte, precisaria adequar a proposta às características deste último. 
Já sob autoria do NCE, foi redigido o projeto Novas ondas - gestão de comunicação, via rádio, em escola numa situação de conflito, com supervisão geral de Ismar de Oliveira Soares, como:

[...] uma proposta de colaboração para mudanças fundamentais nas relações humanas na Escola Municipal de Ensino Fundamental Benedito de Jesus Batista Laurindo, possibilitando que as pessoas se conheçam, ouçam a si mesmas e os mais próximos, para juntos promoverem ações e procedimentos como que recuperem a auto-estima da comunidade escolar, bem como facilitem a sua organização, contribuindo, assim, para alterações significativas na sociedade. (NCE-ECA/USP, 2001, p. 3).

Os objetivos do projeto Novas ondas e os da professora Younis são os mesmos, todavia, esta já não aparece como autora. O problema do financiamento havia sido solucionado: o NCE, agora, assinava o projeto. Mas, ainda era uma proposta para uma única escola.

Como o contato já havia sido estabelecido para a elaboração do programa, pois contava com o apoio e a vontade de realização por parte do Projeto Vida, houve a reformulação da proposta visando abranger todas as escolas municipais do ensino fundamental público da capital paulista. Assim, o que germinou como proposta inserida numa lógica de inovação educacional, para ser desenvolvida como possível solução particular para problema vivido por uma única escola, tornou-se o programa que se alastrou por todas as escolas municipais de ensino fundamental público paulistanas. Dessa maneira, o programa tomou feições que o situam na lógica de reforma educacional, a qual se expressa por "práticas não criadas pelas pessoas que são agentes diretas de sua execução, práticas prescritas por autoridades do poder público, com ampla abrangência, formato homogêneo e alta visibilidade" (GHANEM, 2006, p. 398).

A coordenadora do Projeto Vida, Dirce Gomes (2007), ao comentar como teve conhecimento da proposta inicial do programa, afirma que a intenção do Projeto Vida, no início, tinha como pressuposto um "coletivo, junto aos NAEs, para ver as melhores formas, como é que nós 
faríamos a preparação dos coordenadores e das equipes dos NAEs" para que dessem cumprimento aos objetivos traçados pelo Projeto Vida. Naquele momento, o Projeto Vida não tinha a intenção, ainda segundo sua coordenadora, de agir diretamente nas escolas. A ação se daria nos NAEs, para "prepará-los para que eles fizessem a intervenção direta nas escolas quando necessário". E foi com essa diretriz que, a princípio, o Projeto Vida foi em busca de formas de agir com as escolas.

O NAE 8 tinha uma proposta e mandou-a para nós, de trabalhar exatamente com o rádio, era exatamente com o Ismar e com um determinado custo. Quando nós tomamos conhecimento disso, exatamente com a Fátima, nós consideramos o seguinte: que os custos eram altos. E na realidade era a proposta de uma escola e nós buscávamos coisas mais abrangentes. Então, nós começamos, entramos em contato com o Ismar, mas, buscando outra forma de trabalhar a questão do rádio como uma ação, que começasse nos fins de semana. (Informação pessoal) ${ }^{13}$.

A idéia de o programa ser implantado em atividades nos fins de semana, especificamente aos sábados, parece ter vindo do fato de que, nesse ínterim de elaboração, como Gomes afirma, houve uma articulação com a Unesco: "Pela primeira vez a Unesco conseguiu abrir diálogo com a prefeitura de São Paulo”. Naquele momento, a Unesco desenvolvia o Programa Escola da Paz - em parceria com o governo do Estado do Rio de Janeiro - que consistia em abrir as escolas nos fins de semana "oferecendo atividades de cultura, arte, esporte e lazer", cujo objetivo se configurava em "uma estratégia de combate à violência, em um Estado que possui elevados índices entre jovens" (WAISELFISZ; MACIEL, 2003, p. 30).

Assim, a partir da análise de projetos desenvolvidos nos NAEs, a coordenadora do Projeto Vida teve contato com a idéia de um programa que utilizasse rádio em espaços educativos por meio do projeto de Younis, no NAE 8:

A questão rádio apareceu nesse momento da busca junto aos NAEs de soluções e sugestões que pudessem vir nessa linha de abertura. Foi quando a

\footnotetext{
${ }^{13}$ GOMES, D. Entrevista concedida a Mauro Soares Cordeiro em 19 de dez. 2007.
} 
Fátima apresentou esse projeto que ela havia feito para uma escola que sofria uma violência extrema, e que ela havia apresentado como uma alternativa esse projeto. Ela enviou o projeto para nós, no nível central (ela já era do NAE), quando nós fomos analisar, eu achei muito interessante, mas achei o custo elevado. Como nós teríamos de aplicar recursos do nível central, eu achei que não era razoável aplicar um recurso tão alto para uma única escola. Nós temos de pensar em soluções mais abrangentes. E aí fiz um primeiro contato com Ismar. (Informação pessoal) ${ }^{14}$.

Soares (2008) também assume que estabeleceu contato com o Projeto Vida a partir do

projeto de Younis:

$\mathrm{Na}$ verdade, a proposta da Fátima era trabalhar a educomunicação em uma escola pública para reduzir a violência, usando, para tanto, a linguagem do rádio. A Fátima ingressou no curso [Gestão da Comunicação] e entregou essa proposta para o Projeto Vida. O Projeto Vida, inicialmente, engavetou o projeto, mas, um mês depois, fui chamado à Secretaria pela professora Dirce Gomes, dizendo que tinha com ela o projeto da Fátima e que tinha uma proposta relacionada ao combate à violência e queria ouvir-me a respeito daquilo e tal, porque a Fátima era aluna do curso de Gestão. Eu expliquei do que se tratava e aí a professora Dirce disse o seguinte: que a prefeitura não podia fazer experiências. Se fosse para atender a todas as escolas, o Projeto Vida traria uma proposta como essa. Mas, para fazer experiência numa escola apenas, não seria o caso, porque se tratava de política pública. Política pública não podia fazer experiência. Experiência uma ONG faz, uma universidade faz, mas, não o poder público. Aí, eu expliquei para a professora Dirce que, na verdade, aquela proposta tinha sido gerada numa discussão, que tinha pressupostos anteriores: o que é educomunicação? E experiências como essas já haviam sido implantadas na África do Sul, nos EUA, na América Latina inteira... Não como educomunicação, mas, com o propósito de democratizar a comunicação, colocá-la no centro das ações educativas a partir da autonomia do gestor desse processo. Expliquei a teoria, e o desafio que a Dirce nos deu foi: "Vocês serão capazes de atender todas as escolas da rede?". Aí eu perguntei: "Quantas escolas são da rede?". "Mais de mil escolas." Aí, eu perguntei: "E se formos só com as escolas de ensino fundamental?". " $400,450,455 . . . ”$ Porque ela também quis trazer as quatro escolas de ensino médio que a prefeitura tem. O total daria 455. O desafio que se colocava era que o NCE não tinha mais do que dez pessoas trabalhando. Jamais esse Núcleo teria condição de atender 455 escolas dentro de um período administrativo, que seria a administração da prefeitura naquela época, naquele momento que estava iniciando o semestre [primeiro de 2001], e teria mais 7 semestres pela frente. (Informação pessoal) ${ }^{15}$.

De março a junho de 2001, seguiram-se reuniões institucionais entre o Projeto Vida e o NCE para desenhar a proposta, com a possibilidade de usar recursos do Fundo Nacional de

\footnotetext{
${ }^{14}$ Ibid.

${ }^{15}$ SOARES, I. Entrevista concedida a Mauro Soares Cordeiro em 26 de ago. 2008.
} 
Desenvolvimento da Educação (FNDE/MEC), dentro do Programa Paz nas Escolas (SÃO PAULO, 2002, p. 1).

No entanto, a coordenadora do Projeto Vida conta que, como o prefeito anterior, Celso Pitta, não tinha feito o uso obrigatório do percentual do orçamento em educação, as contas daquela administração foram rejeitadas, o dinheiro do FNDE/MEC só poderia ser repassado como recurso para as Secretarias Municipais de Educação que tivessem aplicado o mínimo exigido por lei, "que, no caso de São Paulo, é 30\% de uma série de impostos".

Mas, o programa já tinha sido esboçado:

Nós tínhamos feito contato com a Universidade de São Paulo, sobre a formação, essa formação seria para alunos, para professores e nós colocamos alguns membros da comunidade. Com o resultado negativo do MEC, o então Secretário, que era o Fernando de Almeida, resolveu encampar com recursos do município esse projeto. Embora nós não tivéssemos orçamentariamente nada já preestabelecido, tínhamos um enorme problema para resolver, tínhamos encaminhado uma parte da solução com esse projeto e houve a aceitação por parte do Secretário. Então, nós começamos. Fizemos um contrato com o NCE. (Informação pessoal) ${ }^{16}$.

O Secretário Municipal de Educação de São Paulo, Fernando de Almeida (2008), diz que tomou a decisão de encampar o programa Educom.rádio por se tratar de uma proposta que era "acoplada a um pensamento universitário"; pressupunha o uso de "tecnologia barata"; porque se tratava de "um projeto com custos palatáveis"; tudo isso afeito a um "peso político enorme":

Isso [o projeto do programa Educom.rádio] conjugava a idéia de você formar o leitor, que lê alto o que está escrito, o escritor, que tem de fazer o roteiro, a comunicação, a escola sendo centro de alguma ação comunitária, o uso de tecnologia barata e acoplada a um pensamento universitário. O Ismar garantia esse aval. Além do mais, esse era um projeto barato. Os custos do projeto, do ponto de vista de equipamento, não era irrisório, mas era muito palatável para os recursos que a Secretaria tinha. Claro que produzir um conteúdo não é barato. A escola gera um produto empedrado. Mesma coisa o livro: ele não necessariamente é um produto de comunicação. É uma

\footnotetext{
${ }^{16}$ GOMES, D. Entrevista concedida a Mauro Soares Cordeiro em 19 de dez. 2007.
} 
comunicação muito pequena, parcelada. Há outras formas de aprender. Transformar um produto que está lá na cabeça do professor, nos Parâmetros Curriculares, em algo que seja vibrante e que o aluno tenha vontade de acessar e acessando, compreenda e, compreendendo, assimile, é um processo longo e caro. Então, eu tinha certeza de que um projeto como o projeto Educom era um projeto muito barato em relação à infra, muito oportuno em relação à política de que os bairros, principalmente os periféricos, tivessem um instrumento de comunicação, que esse instrumento de comunicação tivesse centrado na escola e que os recursos que fossem para gerar conteúdo para isso seriam recursos de formação. Portanto, a prioridade seria de que ia dar condição de professores fazerem trabalhos, e me pareceu de uma felicidade, de uma eficácia, um peso político enorme. (Informação pessoal $)^{17}$.

Com a decisão favorável do Secretário Municipal de Educação, Fernando de Almeida, o programa seguiu sendo elaborado pelo NCE e pelo Projeto Vida.

De março a setembro de 2001, foram reuniões para definir o projeto. As pessoas eram essencialmente o Ismar e a Patrícia. A Patrícia cuidava da parte administrativa. Começamos todo um processo de ver: custos, viabilizar contrato (porque foi um contrato. Foi um serviço que o NCE prestou para a prefeitura, então era objeto de contrato). Então, tivemos de ver todo o respeito a licitação, exatamente com quem seria feito esse contrato (o contrato foi feito com a Fusp - Fundação de Apoio à Universidade de São Paulo), e todas as necessidades. Tem um aspecto jurídico que tem de ser observado com muito rigor, você tem toda uma tramitação que é muito demorada. Acho que levou uns três meses. (Informação pessoal) ${ }^{18}$.

Lima (2008) lembra as reuniões para a elaboração do programa como sendo o momento de explicação de como funcionaria o equipamento proposto para a efetivação do programa, muito mais do que se isso serviria e de que forma para alcançar os objetivos do Projeto Vida:

Fui chamada para as conversas na Secretaria. O que eles se pegavam muito e nos testaram muito era com relação aos equipamentos. Havia um temor da Secretaria de estar implantando oficialmente algo ilegal. Porque nós pregávamos que o projeto de rádio não poderia ser simulação. Tinha de ser programa de rádio mesmo. Não podia brincar de fazer rádio, tinha de fazer rádio de fato. De que forma? Via tecnologia. Eu lembro que eu, especificamente, fui muito inquirida nesse sentido. "Nós vamos implantar algo ilegal aqui na escola?" Na época, me lembro ao lado da professora Dirce desenhando qual seria a infra-estrutura mínima. Depois a prefeitura delegou a tarefa de montar o kit a outra pessoa. As reuniões comigo foram

\footnotetext{
${ }^{17}$ ALMEIDA, F. Entrevista concedida a Mauro Soares Cordeiro em 28 de mar. 2008.
}

${ }^{18}$ GOMES, D. Entrevista concedida a Mauro Soares Cordeiro em 19 de dez. 2007. 
mais no sentido de formular o projeto. Coube, nas reuniões que participei, esclarecimento sobre os equipamentos; mostrar como seria efetivamente um programa de rádio. $\mathrm{O}$ primeiro programa já com equipamento que a prefeitura acatou como ideal foi feito lá na Secretaria, com o grupo do Calaboca já morreu. Nós levamos o nosso grupo e fizemos um programa ao vivo. Foi posto no corredor o equipamento e toda a Secretaria, aqueles andares todos, ouvia um programa que estava sendo realizado pelo Cala-boca já morreu sob minha coordenação. O que me cabia era mostrar a operacionalidade disso. (Informação pessoal) ${ }^{19}$.

Em 31 de julho de 2001, o documento Programa Educom - educomunicação pelas ondas do rádio: construindo a paz pela comunicação é apresentado à Secretaria por Soares (como coordenador do NCE-CCE-ECA/USP), que o assina em 23 de julho de 2001. A contratante é a Secretaria de Educação do Município de São Paulo e a contratada é a Fusp. Nesse contrato, estão como responsáveis pelo programa o diretor executivo da Fusp, Antonio Marcos de Aguirra Massola, e Ismar de Oliveira Soares. (NCE-ECA/USP, 2001a, p. 1).

A respeito dos elementos que possivelmente revelem o exercício de poder e a participação em decisões de políticas, Ghanem (2007, p. 102) nos orienta para pensar nessa perspectiva quando afirma que: "podem-se distinguir os seguintes sentidos que a prestação de serviços de ONGs a órgãos do Estado chega a assumir: a) execução de políticas para o Estado; b) execução de políticas por meio do Estado; c) influência efetiva por construção democrática". Comparando a atuação de ONGs com a do NCE, as evidências levantadas por esta pesquisa levam a concluir que o programa Educom.rádio foi elaborado para ser execução de políticas para o Estado, já que fez parte das ações desenvolvidas pelo Projeto Vida em virtude de objetivos determinados por este e foi, ao mesmo tempo, a execução de uma política por meio do Estado, já que implanta um programa que contém os pressupostos teóricos difundidos e defendidos pelo NCE.

\footnotetext{
${ }^{19}$ LIMA, G. Entrevista concedida a Mauro Soares Cordeiro em 14 de jul. 2008.
} 
As informações colhidas nesta pesquisa e assim detalhadas foram importantes porque se tentou examinar o modo como certos indivíduos ou grupos adquirem maior influência que outros em certos campos de decisões. Para tanto, levou-se em consideração três razões apontadas por Dahl:

1. Certos agentes têm à sua disposição maiores recursos políticos do que outros. $\mathrm{Ou}$

2. Colocados os recursos à sua disposição, alguns agentes usam-nos em maior quantidade para adquirir influência política. $\mathrm{Ou}$

3. Colocados os recursos à sua disposição, alguns agentes utilizam-nos com maior habilidade ou eficiência do que outros. (1966, p. 73).

Para Dahl, recurso político é um meio pelo qual uma pessoa consegue influenciar o comportamento de outras. Os recursos políticos podem, pois, ser muito variados, incluindo dinheiro, informação, alimento, ameaça de força, empregos, amizade, posição social ou o direito de elaborar leis (DAHL, 1966, p. 33).

Não só agentes políticos são diferentes quanto aos recursos dos quais dispõem, utilizam os recursos disponíveis de forma variada, como também afirma Aron:

O grau de autonomia - o número de decisões que o indivíduo pode tomar não é necessariamente proporcional ao nível em que cada um se situa na hierarquia da organização. Além disso, a personalidade daquele que cumpre este ou aquele papel pode aumentar ou diminuir o poder normalmente reservado ao titular deste papel. Em outros termos, uma espécie de dispersão do poder decorre da própria natureza das organizações complexas. Esta dispersão não poderia ser posta em questão senão recusando-se a hipótese necessária a este tipo de análise, a saber, a equivalência das diversas decisões. (1991, p. 37, itálico do autor).

Soares, ao receber o convite do Projeto Vida para a elaboração do programa, percebeu determinado recurso disponível para empreender um projeto que desenvolvesse os pressupostos teóricos defendidos pelo NCE. Mesmo não contando com infra-estrutura, pessoal disponível para a formação proposta ou mesmo experiência que comprovasse trabalhos e resultados obtidos diretamente relacionados com educação escolar, o NCE 
conseguiu influenciar o Projeto Vida a aceitar a configuração de um programa que fizesse uso de meios de comunicação para alcançar seus objetivos. Gomes, como representante da administração superior da Secretaria Municipal de Educação de São Paulo, foi quem acionou os atores que agregavam as condições para que o programa Educom.rádio fosse parte das ações do Projeto Vida, tendo em vista auxiliar "professores, funcionários, pais e alunos a situar o problema da violência dentro de sua esfera de complexidade" (SÃO PAULO, [2004], p. 2). Sendo assim, ainda que estivessem imersos em ambientes institucionais que condicionassem suas escolhas, não será demais afirmar que a decisão política fundamental sobre o formato do programa foi tomada pela relação estabelecida entre a coordenadora do Projeto Vida, Dirce Gomes, e o coordenador do NCE, Ismar de Oliveira Soares.

Diante das evidências observadas até aqui, pode-se perceber alguma similaridade ao que Rus Perez (1998), com o estudo que realizou sobre a política educacional da Secretaria da Educação do Estado de São Paulo, descobriu. Ele destaca que a elaboração dos principais programas daquele órgão foi organizada por grupos de assessores (técnicos, acadêmicos) estranhos à sua estrutura, embora com a participação de alguns técnicos da própria Secretaria. Naquele estudo, ele afirma que: "A Secretaria não consolidou um grupo de técnicos especialistas, de carreira, na formulação de programas" (RUS PEREZ, 1998, p. 140). Ainda que esta parte do presente trabalho se atenha à descrição e exame da elaboração do programa Educom.rádio, que ocorreu no início do governo de Marta Suplicy, pode-se aferir que também não consolidou um grupo de técnicos especialistas, de carreira, em elaboração de programas na Secretaria Municipal de Educação de São Paulo, bem como no novo governo a partir de 2005.

Outra descoberta daquele autor e que também encontra consonância com o caso aqui estudado é o fato de que: 
Os programas e medidas, após a formulação, que não contemplou a participação de agentes dos diversos níveis da estrutura no processo decisório, foram implantados por meio de decretos. Ou seja: os implementadores tomaram conhecimento das mudanças pelo Diário Oficial. A implementação nunca ocorreu pela persuasão ou pela negociação, mas sim pelo "cumpra-se", sem o concurso do implementador, sempre considerado agente passivo. Pode-se dizer que dificilmente os critérios técnicos foram pactuados ou negociados politicamente. (RUS PEREZ, 1998, p. 140).

Dentre as obras que pretenderam estudar o programa Educom.rádio, não há nenhum trabalho que tenha como objeto de estudo especificamente a forma de sua elaboração. Nas duas dissertações de mestrado (FUNARI, 2007; TAVARES JUNIOR, 2007) e em uma tese de doutorado (ALVES, 2007), defendidas na Escola de Comunicações e Artes da Universidade de São Paulo sob orientação de Ismar de Oliveira Soares, há breves referências a relações que suscitaram o programa. Em Funari (2007, p. 13), pode-se ler que:

[...] foi formalizado um contrato entre a Prefeitura e a USP, de forma a possibilitar um diálogo permanente e operacional do NCE com a coordenação do Projeto Vida, organismo que tinha como responsabilidade implantar políticas públicas de combate à violência. Na ocasião da celebração do contrato, era Secretário de Educação do Município de São Paulo, o professor Fernando de Almeida, enquanto a professora Dirce Gomes coordenava o Projeto Vida. Do lado da USP, o Projeto permaneceu sob a responsabilidade do professor dr. Ismar de Oliveira Soares. Respondia pela FUSP, organismo responsável pela administração da verba do projeto, o professor Dr. Antonio Marcos de Aguirra Massola.

Esse relato sucinto talvez tenha se dado porque a intenção da autora foi estudar os relatórios dos mediadores que atuaram no programa, com a determinação de extrair dali "as relações e os processos comunicacionais desenvolvidos com a participação dos mediadores do projeto Educom.rádio" (FUNARI, 2007, p. 15). Tavares Junior (2007, p. 96) também não se demora nesse tema do programa em sua dissertação, seu interesse está centrado na análise qualitativa de peças radiofônicas realizadas, entre 2005 e 2006, por quatro escolas que implantaram o programa. Em sua tese de doutorado, Alves afirma que: 
Em maio de 2001, o NCE apresenta para apreciação do Projeto Vida a proposta Novas Ondas - gestão de comunicação, via rádio, em escola numa situação de conflito. Novas Ondas constituía-se em um projeto-piloto, desenhado para uma escola pública de ensino fundamental - Emef Benedito de Jesus Batista Laurindo -, com duração de 12 meses. Essa proposta inicial foi recusada sob a alegação de que o Projeto Vida não incluiria em sua agenda projetos-pilotos ou ações que se restringissem a uma escola. Foi então que o NCE foi convidado e, por que não dizer, desafiado a formular uma linha de ação para o combate às diversas formas de violências nas escolas, que abarcasse toda a rede de ensino fundamental da cidade de São Paulo. Ao NCE foi solicitada a formulação de uma política pública para as escolas de ensino fundamental da cidade de São Paulo. (2007, p. 164).

Não há conflitos entre as descrições da elaboração do programa nos trabalhos desses três autores. Porém, não descrevem pormenores do momento inicial, aquele primeiro contato em que ambas as partes vislumbrariam a possibilidade de elaborar um programa para a rede municipal de educação pública paulistana. Momento esse do qual se cuida aqui, nesta pesquisa, como de fundamental interesse para se evidenciar os critérios de decisão, negociações e tensões levadas em conta para a definição de programas. Alves (2007) narra o fim do processo que levaria à elaboração do programa Educom.rádio, a partir do momento em que a responsável pelo Projeto Vida já tinha conhecimento de uma proposta para lidar com rádio. Tavares Junior (2007, p. 97) afirma que, no processo de elaboração, "participou a aluna do curso de Gestão de Processos Comunicacionais da ECA-USP, Fátima Younis, professora da Emef Benedito de Jesus Batista Laurindo, que tomou a iniciativa de apresentar o NCE ao Projeto Vida, coordenado pela professora Dirce Gomes”. Mas, não faz menção ao projeto que Younis tinha elaborado e apresentado ao Projeto Vida (PROJETO ESPECIAL DE AÇÃO, 2001). Vale notar que não há referência, nesse excerto da dissertação, de possível fonte de onde se extraiu a observação sobre a relação da professora Younis com o NCE.

Nesta pesquisa, foi examinada também uma tese em educação que expressa a preocupação em estudar um programa desde sua fase de elaboração até os fatores que levaram à sua continuidade. Trata-se da tese de doutorado de Mendes (2006). A autora estudou o Projeto 
Sala de Leitura da rede municipal de ensino de São Paulo desde o início, em 1972, a partir de uma experiência piloto, até 2000. O problema de pesquisa que ela se propõe responder é: Como o Projeto Sala de Leitura da Rede Municipal de Ensino de São Paulo se implanta, se implementa, se institui e permanece? (MENDES, 2006, p. 31). Como hipótese enunciada, a autora diz que "a SL constituiu uma inovação na secretaria de educação e permaneceu a despeito das descontinuidades políticas” (MENDES, 2006, p. 34).

Ainda que a amplitude do enfoque do trabalho de Mendes perpasse diversos governos, ela traz considerações pertinentes a título de comparação com o programa Educom.rádio.

O primeiro assunto a ser tratado pela autora diz respeito à legislação que institui e regulamenta o programa Sala de Leitura. Ela afirma que: "É a legislação que mantém, organiza e implanta as SL [Salas de Leitura] em toda a RMESP [Rede Municipal de Ensino de São Paulo], assegurando condições de execução de programas e garantindo a unidade dentro da diversidade" (MENDES, 2006, p. 35).

No caso do programa Educom.rádio, como se verificará no próximo capítulo, a legislação, por meio de lei e decreto, também desempenha importante papel para a sua continuidade, porque o mantém como política da Secretaria Municipal de Educação de São Paulo.

Sobre a fase de elaboração do programa Sala de Leitura, Mendes informa que ele foi criado em 1972 "por um grupo de professores e especialistas", mas não diz qual a quantidade de envolvidos e se havia grupos distintos. Diz ainda que a demanda pelo programa foi suscitada a partir do "desinteresse e baixo rendimento dos alunos nas áreas de comunicação e expressão observados pelos professores". Com esse motivo, Mendes relata que a Secretaria Municipal de Educação e Cultura (que foi desmembrada em duas secretarias pela Lei $\mathrm{n}^{\circ}$ 8.204, de 13 de janeiro de 1975) iniciou uma experiência piloto envolvendo uma escola e uma biblioteca (Escola Municipal Maria Antonieta D’Alkimin Bastos e a Biblioteca Infantil Anne Frank). E 
que, ainda de acordo com a autora, os bons resultados alcançados com a iniciativa implicaram na criação de um programa denominado Escola-Biblioteca (PEB), em 1973 (MENDES, 2006, p. 116).

A autora faz alguma menção quanto ao número de pessoas e grupos envolvidos com o programa quando narra a criação da Comissão Permanente junto ao Gabinete do Secretário de Educação e Cultura encarregada do planejamento e execução do PEB, instituída com a publicação da Portaria $\mathrm{n}^{\mathrm{o}} 1.330$ de 16 de julho de 1973. Ela informa que essa Comissão Permanente era composta por duas coordenadoras: "uma bibliotecária e uma professora, pertencentes à então Secretaria da Educação e da Cultura e por 13 membros, sendo que nove deles pertenciam às escolas municipais" (MENDES, 2006, p. 133).

Embora as ações para a implementação do programa Escola-Biblioteca foram executadas pela Secretaria, ele não foi implantado em toda rede, a princípio, como foi o programa Educom.rádio. Ao longo do estudo, a autora demonstra os procedimentos que foram realizados em cada governo para a fixação do programa nas escolas. Assim, em 1978, o programa agrupava 45 escolas. No entanto, no mesmo ano, a autora observa que a Secretaria Municipal de Educação resolveu estender o programa para mais 86 escolas: “o que justificou a criação do Setor de Atividades Escola-Biblioteca, em 31 de março de 1978 por meio do Decreto n 15.002" (MENDES, 2006, p. 166).

A autora demonstra também como o programa passa a fazer parte fisicamente da escola. Ela afirma que ele muda de feição: de programa que pressupunha a relação escola-biblioteca, ele passa a constituir uma sala de leitura na escola. E que, com isso, a responsabilidade é transferida para as escolas: "elas deveriam manifestar o interesse e prover as principais condições para a instalação da SL. A análise permite apontar que se tratava de uma posição pela ampliação, mas uma isenção quanto aos meios para tanto" (MENDES, 2006, p. 170). O 
programa Educom.rádio também pressupõe uma sala onde funcionaria a emissora. Esse espaço teria de ser criado pela escola, para nutrir as condições necessárias de acomodação de equipamentos para o funcionamento do programa. Constatou-se que esses espaços tiveram de ser forjados, o que acarretou em muitas delas a utilização da parte de baixo de escadas. Mas, isso não se configurou como fator condicionante para a realização do programa. Das muitas escolas (207) que responderam que o programa não está sendo executado, poucas (7) apontaram como motivo a falta de lugar apropriado para a montagem da emissora de rádio.

A aludida tese informa que o prefeito Antônio Salim Curiati incentivou a criação de mais 300 Salas de Leituras, por meio do decreto $\mathrm{n}^{\mathrm{o}} 18.576$ de 3 fevereiro de 1983, "que deveriam funcionar nas escolas municipais de $1^{\circ}$ Grau, mediante autorização do Secretário Municipal de Educação". Diante desse fato, ela conclui que: "Foi nesse momento que o Projeto SL teve sua consolidação definitiva, ou seja, passou a ser invulnerável e impermeável a possíveis tentativas de seu extermínio, o que não significa que passou a ser refratário à mudança”. Com esse decreto, há a determinação de um profissional que seria encarregado pela Sala de Leitura e que:

[...] deveria ser um professor efetivo de $1^{\circ}$ Grau da Carreira do Magistério, preferencialmente do próprio estabelecimento, que ficava obrigado a regime de trabalho e horário a serem fixados em regulamento; deveria ficar subordinado ao diretor da respectiva escola e receberia orientação normativa e apoio técnico do Setor de Atividades de SL do DEPLAN. (MENDES, 2006, p. 211).

O programa Educom.rádio não teve um profissional encarregado por sua implantação nas escolas definido pela lei ou pelo decreto. De acordo com dados levantados nesta pesquisa, constatou-se que a operacionalização do programa ficou a cargo de variados profissionais da escola: agentes escolares, assistentes de direção, ATEs (Assistente Técnico Educacional), coordenadores pedagógicos, educadores comunitários, diretores, docentes, docentes 
"readaptados", oficineiros ligados a ONGs, POIEs (Professor Orientador de Informática Educacional), vice-diretores. A partir de 2007 é que a formação proposta pelo coordenador do programa, Carlos Lima, deu alguma prioridade à formação inicial dos POIEs para que estes assumissem a execução do programa. Mesmo assim, esses profissionais não se efetivaram como responsáveis pelo programa nas escolas. Essa afirmação encontra evidência pelo fato de que, nesta pesquisa, foram enviados questionários por meio de endereços eletrônicos para 39 escolas das quais se obteve informação de que o programa estava em funcionamento. Desses, 13 questionários respondidos foram devolvidos pelas escolas. Em 4, as pessoas responsáveis pelo programa e pelo preenchimento do questionário eram POIEs. O programa segue operacionalizado por profissionais da escola que se voluntariam para sua execução.

Ainda a respeito da instituição do programa Sala de Leitura por meio do decreto, a autora diz que ele também muda a denominação do setor da Secretaria Municipal de Educação responsável pelo programa: de Setor de Atividades Escola-Biblioteca passa a ser Setor de Atividades de Sala de Leitura.

O programa Educom.rádio não teve um setor criado para responder por sua elaboração ou manutenção. No entanto, como se verá mais detalhadamente a seguir, ele passou de programa especial vinculado ao Projeto Vida para se tornar uma das ações propostas pela DOT.

Assim, dentre as razões que aquela autora constata como sendo determinantes para a continuidade do programa Sala de Leitura está a sua aceitação pela cultura escolar. Isso se deu porque o programa se mostrou uma "inovação vinda da escola". A autora defende que o programa SL tenha sido inovador porque "proporcionou mudanças na organização da escola, foi detalhadamente planejado e objetivou proporcionar melhoria nas condições de leitura de professores e alunos" (MENDES, 2006, p. 217). Essa definição distancia-se do sentido que aqui se adotou para o termo inovação (GHANEM, 2006, p. 398). Talvez a feição que tomou o 
programa Sala de Leitura, assim como o Educom.rádio, seja melhor enquadrável na definição de reforma educacional proposta por Ghanem (2006, p. 398).

Aquela autora faz alguma alusão à possível demanda pelos benefícios alcançados pelo programa como fator de continuidade quando diz que: "Foi um projeto implantado, sedimentado e consolidado, inicialmente, pelo atendimento à necessidade vinda da escola. A condição analítica sempre presente ao longo das décadas permitiu que o Projeto SL fosse considerado imprescindível em todas as administrações" (MENDES, 2006, p. 346). No entanto, ela não apresenta evidências da existência dessa "necessidade vinda da escola" pelo programa, nem mesmo manifestações dessa ordem que tenham partido de profissionais que trabalham nas escolas. Antes, o programa Sala de Leitura, de acordo com os dados colhidos e examinados para aquela tese, foi executado seguindo critérios e diretrizes definidos pelo órgão de nível superior da hierarquia do setor educacional do município de São Paulo, o que ocorreu também com o programa aqui estudado. 


\section{A CONTINUIDADE}

Esta parte foi constituída tendo em vista o desenvolvimento do objetivo 2 estabelecido no projeto desta pesquisa, qual seja: identificar elementos de permanência do programa Educom.rádio. Para isso, foram examinados documentos sobre as políticas da Secretaria Municipal de Educação, o Projeto Vida e o programa Educom.rádio. Parte desses documentos foi coletada e reunida no acervo da Memória Técnica Documental da Secretaria Municipal de Educação de São Paulo. Outros foram encontrados no acervo do gabinete do vereador Carlos Neder na Câmara Municipal de São Paulo. Além disso, foram realizadas entrevistas com responsáveis pelos principais cargos no nível hierárquico superior de administração pública do setor educacional municipal e com profissionais do NCE, os quais foram entrevistados também sobre a elaboração do programa. Foi entrevistado ainda o vereador Carlos Neder, autor do projeto de lei que instituiu o programa em caráter permanente.

Outro tipo de entrevista (por telefone) foi realizado com pessoas que se encarregaram da operacionalização do programa nas 246 escolas que receberam os equipamentos de rádio para a montagem do estúdio: primeiro, foi feito o levantamento em contatos por telefone para localizar aquelas pessoas e, depois, foi aplicado questionário junto a elas para delinear o andamento da implementação do programa nas escolas.

\subsection{A LEI}

Em 28 de dezembro de 2004, portanto, três anos e quatro meses após o início da implantação do programa, a prefeita Marta Suplicy (PT) instituiu o Programa EDUCOM-Educomunicação pelas ondas do rádio no Município de São Paulo com a Lei nº 13.941, aprovada pela Câmara Municipal de São Paulo em sessão de 16 de dezembro de 2004 (SÃO PAULO, 2004b, p. 1). 
Essa lei, em seu artigo $2^{\circ}$, considera nove objetivos para o programa (SÃO PAULO, 2004b, p.1):

I - desenvolver e articular práticas de educomunicação ${ }^{20}$, incluindo a radiodifusão restrita, a radiodifusão comunitária, bem como toda forma de veiculação midiática, de acordo com a legislação vigente, no âmbito da administração municipal;

II - incentivar atividades de rádio e televisão comunitária em equipamentos públicos, nos termos da legislação vigente;

III - capacitar, em atividades de educomunicação, os dirigentes e coordenadores de escolas e equipamentos de cultura do Município, inclusive no âmbito das Subprefeituras e demais Secretarias e órgãos envolvidos, assim como professores, estudantes e demais membros da comunidade escolar;

IV - incentivar atividades de educomunicação relacionadas à introdução dos recursos da comunicação e da informação nos espaços públicos e privados voltados à educação e à cultura;

V - capacitar os servidores públicos municipais em atividades de educomunicação;

VI - incorporar, na prática pedagógica, a relação da comunicação com os eixos temáticos previstos nos parâmetros curriculares;

VII - apoiar a prática da educomunicação nas ações intersetoriais, em especial nas áreas de educação, cultura, saúde, esporte e meio ambiente, no âmbito das diversas Secretarias e órgãos municipais, bem como das Subprefeituras;

VIII - desenvolver ações de cidadania no campo da educomunicação dirigidas a crianças e adolescentes;

IX - aumentar o vínculo estabelecido entre os equipamentos públicos e a comunidade, nas ações de prevenção de violência e de promoção da paz, através do uso de recursos tecnológicos que facilitem a expressão e a comunicação.

Estabelece assim a utilização de dispositivos de comunicação como atividade a ser incentivada e implementada pelo poder público em diversos âmbitos e setores da administração do Município de São Paulo.

\footnotetext{
${ }^{20}$ Esse termo é apresentado no corpo da lei como: "o conjunto dos procedimentos voltados ao planejamento e implementação de processos e recursos da comunicação e da informação, nos espaços destinados à educação e à cultura, sob a responsabilidade do Poder Público Municipal, inclusive no âmbito das Subprefeituras e demais Secretarias e órgãos envolvidos" (SÃO PAULO, 2004b, p. 1).
} 
O projeto dessa lei é de 2002 (Projeto de Lei n 556/02, do vereador Carlos Neder, PT) e foi apresentado na Câmara Municipal de São Paulo em 24 de setembro de 2002, ou seja, um ano após o início da implantação do programa Educom.rádio. No projeto de lei, já constam os sete artigos que fariam parte do texto da lei e os mesmos objetivos determinados pelo artigo $2^{\circ}$, com uma pequena variação: no projeto, há bem menos repetição do neologismo educomunicação do que na lei. No texto do projeto de lei, excetuando-se o nome do programa (Educom.rádio - educomunicação pelas ondas do rádio), o termo educomunicação é registrado duas vezes: no artigo $2^{\circ}$, no objetivo V: "Capacitar os estudantes e demais membros da comunidade escolar em atividades de educomunicação"; e aparece mais uma vez em forma de condição para a participação de pesquisadores de universidades na implementação do programa, no artigo $3^{\circ}$. Na lei, também excetuado o nome do programa, há nove ocorrências para educomunicação distribuídas pelos objetivos e também a do artigo $3^{\circ}$.

O projeto de lei já propunha, no artigo $3^{\circ}$, que:

Para implementar o Programa instituído por esta Lei, o Poder Executivo assegurará a participação das diversas secretarias afetas ao programa, de representantes de universidades que desenvolvam práticas de educomunicação, de representantes de grêmios estudantis e entidades representativas dos estudantes, de representantes do Sindicato dos Jornalistas e do Sindicato dos Radialistas e das associações de rádios comunitárias. (SÃO PAULO, 2002a, p. 2).

A lei aprovada mantém o artigo dessa forma, assegurando a participação de diversos grupos na implementação do programa, apenas acrescentada a idéia de que essa participação seria configurada por um Comitê Gestor: “cuja composição e competências específicas serão definidas em decreto". A lei não especifica como seria distribuída a responsabilidade pela implantação entre os grupos envolvidos no referido Comitê, tampouco define o que viria a ser a participação de cada representante. 
Esse mesmo artigo $3^{\circ}$ anuncia, em seu parágrafo $1^{\circ}$, que, dentre os grupos assegurados para a participação no Comitê Gestor, os representantes de universidades serão os "que desenvolvam pesquisas e práticas de educomunicação". Essa limitação pode ser que sentenciasse a primazia do grupo do NCE e seus parceiros para participar desse Comitê, uma vez que é o NCE que divulga pesquisas e realiza práticas que teriam contribuído para firmar um novo campo denominado pelo neologismo educomunicação (NCE-ECA/USP, 2004, p. 3) ${ }^{21}$. Para uma melhor abordagem a respeito da busca de legitimação de um novo campo de saber referente à educomunicação, consulte o trabalho de Segawa (em fase de elaboração) ${ }^{22}$.

No contrato inicial firmado para a execução do programa, pode-se ler que: "O programa será implementado a partir do conceito de Educomunicação, desenvolvido pelo NCE, explicado no item “justificativa"” (NCE-ECA/USP, 2001a, p. 2). No item "justificativa” citado, observa-se a seguinte definição para o termo:

[...] caminhos e modalidades para a promoção de uma integração estratégica entre professores, profissionais da mídia e educandos (crianças, jovens e suas famílias), de forma a obter melhores resultados com a presença das tecnologias da informação na sociedade contemporânea e em seus respectivos espaços domésticos. É o que se denomina como Educomunicação. (NCE-ECA/USP, 2001a, p. 6).

O fato de ter limitado a participação a um dos grupos que elaboraram o programa parece ter sido motivado não apenas pelo contrato inicial fazer referências a práticas e estas constarem como metodologia requerida para a sua implantação. Há evidências de que houve participação direta do NCE na decisão e definições dos objetivos que constam na lei, para além de um

\footnotetext{
${ }^{21}$ É possível ler sobre o processo de constituição de um campo relacionado à educomunicação em Lima e Melo (2007) - disponível também em: <http://portal.mec.gov.br/secad/arquivos/pdf/educacaoambiental/educacaoambiental_naescola.pdf>. Acesso em: 15 set. 2008.

22 SEGAWA, F. Programa Educom.rádio: um estudo sobre representações. Dissertação de mestrado a ser defendida nesta Faculdade de Educação da Universidade de São Paulo, 2009.
} 
possível aproveitamento do texto que justificava a implantação do programa. A seguir, algumas evidências serão apresentadas.

Essa participação parece ter sido motivada muito mais em função de um tipo específico de influência, a influência assegurada, distinguida por Dahl (1966, p. 89) como sendo aquela em que "a probabilidade de aquiescência é muito alta". Essa aquiescência decorreria menos da justificativa apresentada como parte do contrato inicial para a implantação do programa do que da autoridade que é conferida ao NCE por ser um órgão pertencente à Universidade de São Paulo. Sobre esse aspecto, Dahl (1966, p. 40) afirma também que: “Autoridade é forma altamente eficiente de influência".

Por outro lado, há a ressalva de que essa aquiescência aos desígnios do NCE pode não ter "custado muito" a esse legislador. Os pressupostos para essa afirmação perpassam diversos aspectos, dentre os quais: Neder também tem formação universitária (mestrado em Saúde Pública pela Universidade de Campinas - Unicamp) e apresentar um projeto justificado por pesquisadores de uma universidade pública lhe conferiria status, respaldo para aprová-lo; já dedicava confiança à decisão do Executivo: qualquer projeto proposto por este, seria defendido no Legislativo; a fidelidade partidária nutrida por Neder; e, talvez o mais importante, o mandato desse vereador já era a favor de uma lei que tratasse do tema envolvendo o setor da Educação, por já ter feito aprovar outra lei (13.096) sobre o Programa de Prevenção da Violência nas Escolas. No entanto, o fato da utilização do termo educomunicação se constitui como evidência para afirmar que houve influência: Neder não utiliza esse termo em textos ou justificativas de outros projetos de leis. Assim, a definição de influência como sendo uma relação, que é apresentada por Dahl (1966, p. 63, grifo do autor), coaduna com o caso aqui estudado: "Podemos usar uma terminologia específica bastante conveniente e dizer que a influência é uma relação entre agentes em que um agente induz 
outros agentes a agirem por uma forma que de outra maneira não agiriam”. De alguma forma, o NCE induziu Neder a apresentar a lei da maneira como foi escrita.

Esse tipo de influência se fez perceber em outros momentos dos processos de decisão aqui examinados, tanto como fator a considerar para a implementação do programa quanto para sugerir a permanência sob a responsabilidade do referido núcleo, como se verificará em outros documentos comentados.

Lindblom (1981) também se atém a entender a autoridade como fundamento da decisão política no jogo do poder. Inicia sua abordagem afirmando que esse seria um dos métodos de controle e que, em certos casos, ocupa posição fundamental. Esse autor distinguiu dois processos pelos quais as pessoas usam tais métodos:

\begin{abstract}
No primeiro, utilizam métodos como a persuasão, a ameaça, o oferecimento de vantagens, com relação às pessoas que desejam controlar, na oportunidade específica em que desejam exercer tal controle. No segundo, empregam os mesmo métodos, porém só ocasionalmente, para induzir a aceitação de uma norma permanente de obediência. Só este segundo processo estabelece a autoridade: se respeito uma regra de obediência com relação a uma pessoa, ela tem autoridade sobre mim. (LINDBLOM, 1981, p. 45 , grifo do autor).
\end{abstract}

No caso estudado aqui se coloca como manifestação desse segundo processo apontado por aquele autor. Neder teria sido induzido pela justificativa apresentada pelo NCE a usar o termo educomunicação no projeto de lei. O legislador obedeceu à nomenclatura proposta como adequada para compor seu texto e, assim, reconheceu a autoridade do Núcleo. A obediência, para Lindblom (1981, p. 46), é a regra mais importante no jogo do poder e é esta que fundamenta a autoridade.

No entanto, pode-se incorrer em suposição exagerada ao afirmar que o NCE fez uso direto de sua autoridade sobre a escolha de Neder. A utilização desse método pode ter sido praticada de forma indireta, nos termos que anuncia Lindblom: 
Entre os formuladores de política, a maioria das vantagens que podem oferecer depende da sua autoridade. Por exemplo: devido à sua autoridade, um congressista pode oferecer um voto em troca de algo. Um burocrata pode ter autoridade sobre uma decisão potencialmente benéfica a um outro formulador de política, e propor-lhe assim uma troca de favores. A autoridade e o intercâmbio estão entrelaçados. Possivelmente a forma mais comum do uso indireto da autoridade seja a obtenção de vantagem mediante troca - como acontece, por exemplo, nas ofertas de emprego feitas pelos políticos para promover seu apoio eleitoral. (LINDBLOM, 1981, p. 48).

O caso pesquisado até aqui pode ter sido o de obtenção de vantagem mediante troca: o NCE, cedendo a justificativa para o projeto de lei, obteve em troca o reconhecimento de sua metodologia como eficaz para a implantação de programas. O vereador Carlos Neder, permitindo que se transcrevesse a definição dada pelo Núcleo para a implantação do programa prevista no contrato, obteve em troca, além de um importante aliado para difundir a lei, inserção no setor da educação e comunicação.

Mesmo com a vantagem, o autor do projeto da lei não vê na definição da metodologia uma limitação ou prioridade de execução concedida ao NCE. Ainda que considere os integrantes desse núcleo como "interlocutores credenciados a estar numa relação de parceria com o Poder Executivo":

Há um cuidado na redação do projeto [de lei] de permitir que outras entidades e associações possam disputar esse mesmo nicho, ou nele atuar, na medida em que o que se espera é que, havendo uma consistência do conceito e na execução da proposta, mais entidades, associações e núcleos viessem a elaborar e interagir e até mesmo modificar ou questionar em parte a proposta. (Informação pessoal) $)^{23}$.

Ainda sobre a denominação da relação estabelecida nesse momento para a confecção da lei,

Neder sugere que não se trata de lobby. Para o vereador, seria um tipo de lobby praticado pelo NCE "se a proposta tivesse vindo no sentido de limitar a oportunidade de outros participarem ou de criar uma dependência do Poder Executivo de determinadas tecnologias". Para

\footnotetext{
${ }^{23}$ NEDER, C. Entrevista concedida a Mauro Soares Cordeiro em 15 de maio de 2008.
} 
corroborar essa afirmação, diz que o "Poder Executivo tem ampla liberdade de legislar mediante decreto, portarias, quanto à forma de implementação da proposta". Diz ainda que houve a preocupação, no momento de redação do projeto da lei, de que "outros pudessem estar disputando legitimamente espaço na implementação da proposta, sem dar a primazia ou exclusividade à USP, ECA e ao Núcleo".

Em entrevista colhida nesta pesquisa junto ao coordenador do NCE, este assume ter participado da elaboração da lei na qualidade de colaborador, tanto para conferir os termos da lei quanto os do decreto (que será examinado mais adiante):

[...] eu ingresso no processo para discuti-la, desenvolvê-la com os conceitos. Então, eu vou colaborar com o Neder tanto no texto da lei quanto com a prefeitura de São Paulo, na época do professor Pinotti, na regulamentação da lei. O professor Pinotti me pede também uma colaboração para regulamentar a lei. Minha contribuição foi retomar os textos, reelaborá-los e devolvê-los para os autores. (Informação pessoal) ${ }^{24}$.

Embora haja essas evidências da participação do NCE na redação da lei, este não conseguiu a prioridade da qual gozou, entre setembro de 2001 e dezembro de 2004, de continuar à frente da implantação do programa no novo governo, a partir de 2005. Mas a atividade de influência em relação aos desígnios do programa continuou. Esse fato será mais bem detalhado na seqüência deste trabalho.

Anexado ao projeto da lei, há uma justificativa que começa com uma citação referida ao Professor Ismar de Oliveira Alves [sic], do Núcleo de Comunicação e Educação (NCE) do Depto. de Comunicações e Artes da ECA-USP, na qual se discorre que:

Essa nova proposta oficial [os Parâmetros Curriculares Nacionais] solicita o diálogo com a interdisciplinaridade, provocando a interação de fatores técnicos, humanos e pedagógicos. Ademais, indica a importância da união do científico ao cotidiano, o que pode ajudar a diminuir muito, a curto prazo,

\footnotetext{
${ }^{24}$ SOARES, I. Entrevista concedida a Mauro Soares Cordeiro em 26 de ago. 2008.
} 
o abismo criado entre a escola e os outros segmentos da sociedade, abrindo uma brecha para o prazer em aprender. (SÃO PAULO, 2002a, p. 3).

Embora haja a utilização de aspas no trecho citado na justificativa, não apresenta nenhuma referência de onde pode ser encontrado tal excerto. A mencionada justificativa recorre ao argumento de que o Projeto Vida, do qual o Projeto Educom-Educomunicação pelas ondas do rádio é uma das ações, “cumpre os dispositivos da Lei Municipal n 13.096/2001, que institui o Programa de Prevenção da Violência nas Escolas, de nossa iniciativa parlamentar". Informa também que "o Educom.radio capacita os alunos a produzirem spots e programas de radio sobre os mais diversos temas da vida escolar" [sic]. Reporta à necessidade de obtenção de equipamento de rádio para a montagem da estação emissora nas escolas: "O equipamento de produção e transmissão sonora é a interface necessária à interação entre os membros da comunidade escolar" (SÃO PAULO, 2002a, p. 3). Essa justificativa termina anunciando que: “Através da aprovação do presente projeto de lei, objetivamos a perenização destes programas, de tal forma que não dependam das circunstâncias institucionais momentâneas" (SÃO PAULO, 2002a, p. 4).

O texto da justificativa cumpre parte da função de apresentar o tema proposto pelo projeto de lei. É uma prática típica nos trâmites de aprovação de leis na Câmara Municipal de São Paulo. No caso específico, Neder (2008) conta que:

O Parlamento funciona com uma lógica que não devia ser a adotada. Depende muito de acordo de lideranças, então, os projetos vão tramitando nas comissões, enfrentam resistências ou causam perplexidade. No caso do Educom: "O que é isso? Que nome é esse? Qual é o conceito de educomunicação?" etc. Daí a razão de nós termos feito eventos, inclusive na Câmara, durante a tramitação do projeto, mobilizando setores formadores de opinião para convencer os vereadores de que a proposta era séria e factível. (Informação pessoal) $^{25}$.

\footnotetext{
${ }^{25}$ NEDER, C. Entrevista concedida a Mauro Soares Cordeiro em 15 de maio de 2008.
} 
Outra idéia contida no texto da justificativa é o objetivo de conferir perenização de políticas por meio de força de lei. A entrevista realizada com Neder reafirma essa possibilidade, já que, para ele, o fato de existir a lei, como um marco "para aqueles que se mobilizam em defesa da proposta", pode vir a se tornar "instrumento para a luta", que porventura venha a ocorrer, da sociedade pela permanência de determinado programa. No entanto, ele ressalva que apregoar a lei como fator preponderante para a continuidade "seria dar uma importância indevida à lei, porque ela não tem essa condição de garantia". Lembra ainda que, "tanto é assim, que existem leis e leis que não são observadas, cumpridas etc.”.

A intenção de conferir continuidade a programas por meio de aprovação de leis parece também ter sido o fator que levou ao contato entre o Executivo, representado pela ação da coordenadora do Projeto Vida, da Secretaria Municipal de Educação, Dirce Gomes, e o Legislativo, no caso, o vereador Carlos Neder. Em depoimento colhido junto à coordenadora, ela afirma que:

\begin{abstract}
Em educação, você tem determinadas práticas que podem ser da iniciativa única e exclusivamente do Executivo. Pode ser uma decisão de Secretário, de prefeito, e ele implanta determinado programa. O que acontece é que esses programas acabam tendo a duração de uma gestão. Terminada essa gestão, vem uma nova (se for uma continuidade [mesmo partido], muito bem...), se vem um outro gestor é quase normal que ele queira apagar o anterior e queira colocar coisas novas. O único jeito de você ter uma continuidade dos procedimentos é que isso seja apoiado em lei. Um pouco foi o que nós fizemos. (Informação pessoal) ${ }^{26}$.
\end{abstract}

Gomes (2007), comentando o propósito de apoiar em lei a continuidade do programa aqui estudado, chama a atenção para outro fator que parece ser determinante para a descontinuidade de programas: o fato de que carregam a marca distintiva do programa do partido que estava no governo no momento de sua formulação.

\footnotetext{
${ }^{26}$ GOMES, D. Entrevista concedida a Mauro Soares Cordeiro em 19 de dez. 2007.
} 
A respeito de fatores que podem ser considerados como influentes para a continuidade, assume que a prática de elaboração de leis é uma das formas racionalmente orientadas para assegurar a permanência:

Já havia uma participação minha, uma tentativa de viabilizar essas ações transformando em leis. Porque aí fica mais difícil a gestão seguinte derrubar. Um pouco isso nós fizemos na gestão da Marta. Nós [equipe do Projeto Vida] tentamos junto com o Neder, era quem já tinha uma proposta mais ou menos parecida, de abertura das escolas, de projetos de prevenção da violência, nós ajudamos até na redação da lei [Programa de Prevenção de Violência nas Escolas, Lei Municipal n 13.096, de 2001], conseguimos a aprovação da lei que transformasse esse programa de prevenção da violência, com esse caráter multidisciplinar, em lei. Aí as gestões futuras teriam como amarrar a continuidade. (Informação pessoal) ${ }^{27}$.

Essa ação conjunta entre o Executivo, como elaborador de políticas, e o Legislativo, com a função de criar leis para viabilizar a garantia de continuidade, pôde ser percebida pelo menos nesse caso, no governo do PT, sob a responsabilidade da prefeita Marta Suplicy, a partir do Projeto Vida coordenado por Gomes (2007):

Com o advento do Educom, nós fizemos o mesmo procedimento. Se o Educom, que é um programa que tem se mostrado com resultados bem razoáveis, ele pode dar voz ao aluno... Essencialmente nosso aluno da rede municipal não tinha voz, era sempre um regime muito autoritário e se ele não tinha voz ele achava através da pichação, da depredação, uma forma de comunicar e dar o recado dele... Então, nós achamos que o Educom era uma iniciativa que deveria ser preservada. Houve uma segunda lei, por iniciativa também do Neder, quase que complementar à primeira, dando continuidade, quer dizer, instituindo o Educom. Aquilo que nós pensamos que fosse uma prática em políticas públicas, que na medida em que você visse que uma determinada prática testada era viável, procurar consolidá-la através de uma lei para garantir a continuidade. (Informação pessoal) ${ }^{28}$.

Neder reafirma essa iniciativa e acrescenta que o programa fazia parte do interesse de seu mandato e que o motivo para apresentação do projeto de lei foi:

[...] por acreditar na proposta [executada por meio do programa Educom.rádio] e por entendê-la em risco, porque ela traduzia uma

\footnotetext{
27 Ibid.

28 Ibid.
} 
determinada concepção do papel do Estado, sobre a reforma do Estado, e o Estado como indutor de políticas e permeado por mecanismos de democratização e participação da sociedade, que era preciso dar um grau de segurança maior. (Informação pessoal) ${ }^{29}$.

Abbonizio (2007, p. 61), em pesquisa sobre a retomada do programa Mova-SP (Movimento de Alfabetização de Jovens e Adultos) em 2001 pela Secretaria Municipal de Educação de São Paulo, percebeu que uma série de medidas institucionais foram tomadas "a fim de tentar garantir sua continuidade em futuras administrações". Essas medidas teriam sido suscitadas em contrapartida ao que identificou como trauma da interrupção sofrida na primeira experiência do programa diante da mudança de prefeitos, em 1992-1993. Dentre as medidas, estavam a regulamentação do programa por meio do Decreto 41.109 assinado pela prefeita Marta Suplicy em setembro de 2001; a intensificação das exigências de ordem administrativoburocrática para a celebração dos contratos entre organizações sociais e o poder público; a prestação de contas. A autora afirma ainda que "o objetivo foi o de formalizar ao máximo a parceria para evitar retaliações futuras de ordem política”.

Paralelamente às pretensões aqui descritas, a prática como se deu a forma de elaboração do projeto de lei pode ter encontrado justificativa também na própria maneira de como se dá o Processo Legislativo na Câmara Municipal de São Paulo, onde há a seguinte possibilidade: "Durante a tramitação nas Comissões poderão ser realizadas audiências públicas, por mandamento legal ou a pedido de entidades e dos cidadãos, para manifestação dos especialistas e interessados sobre os projetos em análise” (SÃO PAULO, 2008a).

Neder (2008) atesta esse processo quando afirma que, para a apresentação do projeto na Câmara, foram realizados reuniões e eventos para dialogar diretamente com as pessoas envolvidas na implementação do programa Educom.rádio, "até para que o projeto não ficasse

\footnotetext{
${ }^{29}$ NEDER, C. Entrevista concedida a Mauro Soares Cordeiro em 15 de maio de 2008.
} 
dissociado, de um lado, do que já eram as suas diretrizes, mas, do outro, das perspectivas novas que foram surgindo a partir de dificuldades observadas na implementação da proposta". (Informação pessoal) $)^{30}$.

Esse legislador justifica a possibilidade de influências, no caso aqui descrito, quando afirma que um projeto de lei não surge apenas da "idéia ou da vontade de um parlamentar": "Em geral, eles decorrem de situações, aspirações e de formas de organização da sociedade, que acabam por incentivar a realização desses projetos para atender essas expectativas". (Informação pessoal) $)^{31}$.

No entanto, as situações e aspirações evocadas aqui podem ter contado com um componente decisivo para que fosse possível encontrar vazão por meio de projetos: a estratégia adotada pode ter sido vislumbrada também como resultado da parcela majoritária que o partido ocupante do Executivo dispunha na Câmara Municipal de São Paulo, desde o resultado eleitoral de 2000. Dos 55 vereadores eleitos naquele ano, a coligação PT, PC do B, PCB e PHS somava 19 representantes, o que a configurou como a coligação com maior número de parlamentares.

\begin{tabular}{|l|c|}
\hline Partidos & Vereadores eleitos \\
\hline PT / PC do B / PCB / PHS & 19 \\
\hline PSDB (sem coligação) & 8 \\
\hline PFL / PMDB & 7 \\
\hline PP (sem coligação) & 6 \\
\hline PSB / PDT & 4 \\
\hline PTB / PSD & 4 \\
\hline PL (sem coligação) & 3 \\
\hline PPS (sem coligação) & 2 \\
\hline Prona (sem coligação) & 2 \\
\hline total & 55 \\
\hline
\end{tabular}

Quadro 1: Vereadores eleitos e eleitos por média na eleição de 2000 no município de São Paulo.

(Fonte: www.tse.gov.br/sieeseireweb/seire.jsp?modulo=RE\&anoConexao=2000)

\footnotetext{
${ }^{30}$ NEDER, C. Entrevista concedida a Mauro Soares Cordeiro em 15 de maio de 2008.

${ }^{31}$ Ibid.
} 
A relação entre Executivo e Legislativo tratada aqui coincide com o caso da Coalizão Fisiológica de Governo identificada por Andrade:

Na situação de CFG [Coalizão Fisiológica de Governo], não se observam casos de cooperação no Legislativo. A oposição minoritária é excluída do processo decisório. Visto que nessa situação o Legislativo abriu mão dos seus poderes de veto, obstrução e controle, bem como de qualquer responsabilidade pela formulação de políticas, seu lugar no processo decisório é reduzido à homologação das decisões do Executivo. (1998, p.28).

Necessário se faz levar em consideração também o fato de que, em 2001, o vereador Carlos Neder tornou-se líder da bancada do seu partido (PT) na Câmara Municipal de São Paulo. Constituiu-se assim como responsável no Legislativo Municipal pela defesa do programa de seu partido e, como um dos resultados decorrentes dessa responsabilidade, esteve obrigado a conferir “sustentação política ao Governo Marta Suplicy” (NEDER, 2008).

É possível ler a diretriz que fundamenta essa relação e a possibilidade de influência na elaboração de políticas também orientada pelo Estatuto do Partido dos Trabalhadores, aprovado pelo Diretório Nacional desse partido em 11 de março de 2001. No Capítulo 3, Artigo 63, que dispõe sobre as bancadas parlamentares, está escrito que:

As Bancadas de Parlamentares estão subordinadas às deliberações das instâncias partidárias de direção.

$\S 1^{\circ}$ : As Bancadas são consideradas órgãos do Partido que definem a ação parlamentar de acordo com as Resoluções adotadas pela instância de direção correspondente e pelas demais instâncias superiores do Partido.

$\S 2^{\circ}$ : É dever das Bancadas Parlamentares, apoiadas pela assessoria parlamentar dos gabinetes e da liderança, cooperar com o Partido para a elaboração das políticas públicas, dos bancos de dados, dos projetos institucionais e das propostas temáticas. (PARTIDO DOS TRABALHADORES, 2008, p.15). 
Nesse mesmo estatuto, na Seção V, Artigo 85, há a especificação da função da bancada de vereadores, que: "constitui a instância de ação parlamentar do Partido, no âmbito municipal" (PARTIDO DOS TRABALHADORES, 2008, p. 19).

Andrade (1998, p. 16), preocupado com o processo decisório na Câmara dos Vereadores e na Assembléia Legislativa de São Paulo, observando a natureza das decisões e do processo de negociação, estabelece um modelo decisório dividido em quatro itens. Interessa-nos, a princípio, chamar atenção para o item "b", onde explica que: "O objetivo fundamental dos decisores - no caso, os vereadores e deputados estaduais, bem como membros do Executivo é a continuidade da sua carreira política, seja através da reeleição, seja pela ocupação de outros cargos públicos”.

A aceitar a explicação contida nesse item do modelo proposto, podemos inferir que Neder sofreu influência ou pressão para ser o proponente de projetos de leis que pudessem obedecer aos desígnios do partido, conferindo a almejada sustentação política requerida pelo governo, ou mesmo privilegiando a política de determinado setor, no caso a Secretaria Municipal de Educação por meio do Projeto Vida. Porém, a aprovação do projeto de lei que instituiria o programa Educom.rádio também carregava o interesse de seu mandato nesses temas, ou, pelo menos, atribuía uma novidade e aumentava as áreas de atuação de seu mandato, propagando a visibilidade. Essa afirmação encontra como evidência o fato de que, dos projetos de leis que o mandato de Carlos Neder engendrou nos trâmites de aprovação da Câmara Municipal de São Paulo, 39 foram sancionados como leis entre 2000 e 2004. Dessas, 20 eram relacionadas ao setor da Saúde e apenas duas, ao de Educação: a que instituiu o Programa de Prevenção da Violência nas Escolas, Lei $\mathrm{n}^{\mathrm{o}}$ 13.096; e a que tratamos mais detidamente aqui, a que institui o Programa Educom - Educomunicação pelas ondas do rádio no Município de São Paulo, Lei no 13.941 (NEDER, 2008a). 
A hipótese sugerida por Andrade (1998, p. 17) expõe que os parlamentares tendem a avaliar com liberdade e flexibilidade estratégica o campo de oportunidades em que atuam porque, presume, o interesse em prosseguir na carreira política parlamentar é o motivo principal entre eles 'e não de se reeleger primordialmente 'pela causa' ou mesmo de promover prioritária e diretamente os interesses regionais ou setoriais que representam". Porém, também ressalva que: "Não há por que deduzir daí uma completa ausência de convicções éticas ou políticas entre os parlamentares".

Sobre os desdobramentos da aprovação da lei e as consequiências para a possível continuidade do programa Educom.rádio, em entrevista para fins desta pesquisa, Soares (2008) avalia que:

\begin{abstract}
A lei, ela visava primeiramente legitimar essa prática como uma prática importante e levá-la para várias Secretarias. Então, o Educom, pela lei, não é entendido como algo da Secretaria de Educação, mas algo para ser levado para todas as Secretarias. Porém, ela localiza o projeto na Educação. Esse é o ponto fraco da lei. Ao localizar, as outras Secretarias desconhecem essa lei, porque é uma lei da Educação. E a Educação não sabe como fazer para articular as demais Secretarias. (Informação pessoal) ${ }^{32}$.
\end{abstract}

\title{
6.2 A RADIODIFUSÃO E A OBORÉ
}

Em 2005, na sessão de 11 de maio, portanto, início do governo municipal sob a responsabilidade de José Serra (PSDB), a Câmara Municipal de São Paulo aprovou a Lei no 14.013, promulgada pelo prefeito em 23 de junho de 2005. Essa lei dispunha sobre a exploração do Serviço de Radiodifusão Comunitária de São Paulo. Para Neder (que, em 2005, assumiu o cargo de deputado estadual pelo PT), essa lei conteve uma característica diferenciada das demais, foi apresentada por dois vereadores de partidos diferentes que freqüentemente estão em disputa:

[...] muitos se surpreenderam pelo projeto ter sido apresentado por um vereador do PT e um do PSDB, conjuntamente. [...] Nós votamos,

\footnotetext{
${ }^{32}$ SOARES, I. Entrevista concedida a Mauro Soares Cordeiro em 26 de ago. 2008.
} 
aprovamos o projeto, o vereador Montoro e eu, com resistência no Plenário e o prefeito Serra sancionou a lei, de forma pioneira no país, e depois houve uma ação que bloqueou os efeitos do projeto e ele permanece agora em discussão no Poder Judiciário ${ }^{33}$. (Informação pessoal) ${ }^{34}$.

Para além da discussão do conteúdo da lei 14.013 e também dos caminhos trilhados desde sua elaboração até a aprovação, essa promulgação parece ter contribuído para colocar o assunto da radiodifusão em voga no novo governo. Isso pode ter se constituído como argumento favorável e como um dos fatores levados em consideração para o que se pensava como continuidade do programa Educom.rádio. Em audiência com os interessados em constituir o Comitê Gestor do programa, o novo Secretário Municipal de Educação, José Aristodemo Pinotti, manifestou que o programa, ao obter continuidade, poderia "se consolidar como rádio comunitária abrangendo não só o ambiente escolar, mas a comunidade próxima à escola" (OBORÉ, 2008).

Essa audiência com o Secretário foi realizada em 22 de dezembro de 2005, relatada no sítio da empresa Oboré, para tratar da regulamentação do Comitê Gestor do programa Educom.rádio. Ainda que não se trate de documento oficial, esse sítio informa assuntos bastante pertinentes a esta pesquisa. São anunciados ainda como presentes à referida audiência: Jarbas Mazzariello, coordenador Educom.rádio na Secretaria Municipal de Educação, naquele momento; o deputado Carlos Neder; a vereadora Soninha Francine e o assessor jurídico Luis Nader; Ismar de Oliveira Soares (coordenador do NCE); Margareth Santos (Escritório Modelo D. Paulo Evaristo Arns); Sergio Gomes (diretor da Oboré, mas, representando o Itaú Cultural) e Terlânia Bruno, representante do Sindicato dos Jornalistas no Estado de São Paulo.

No entanto, sete meses antes, em 30 de abril de 2005, o Secretário de Educação, ao proferir palestra na mesma Oboré, como atesta o sítio dessa empresa, anunciou que apoiava o

33 A Abert (Associação Brasileira de Emissoras de Rádio e Televisão) entrou com ação alegando inconstitucionalidade para bloquear os efeitos da lei, o que a remeteu a decisão do Poder Judiciário.

${ }^{34}$ NEDER, C. Entrevista concedida a Mauro Soares Cordeiro em 15 de maio de 2008. 
programa Educom.rádio e garantiu que conferiria continuidade a ele. Afirmou ainda, em conformidade com a idéia de o programa se aproximar da atuação das rádios comunitárias: "O que eu penso é que o Educom deve ser uma rádio comunitária que irradia a partir da escola. Seria uma maravilha para falar de educação para a saúde, da prova de matemática que houve no dia anterior, ou seja, a integração com a comunidade seria muito potencializada" (OBORÉ, 2008).

A idéia de que o estúdio de rádio, de irradiação e freqüência restritas, previsto para a implantação do programa nas escolas, pudesse vir a se transformar em rádio comunitária parece consensual entre os atores envolvidos no processo de decisão para a possível continuidade do programa. No entanto, ao se deter nessa questão, vem à baila outro grupo que operou com visível influência no processo de pressionar autoridades responsáveis por decisões com vistas a viabilizar a continuidade. As ações promovidas pela Oboré se fazem notar em muitos documentos examinados nesta pesquisa. Antes de passar aos documentos, cabe ressaltar que essa empresa teve envolvimento direto na implantação do programa: foi responsável por palestras que tratavam dos eixos temáticos Saúde e Comunicação e Políticas Públicas de Comunicação durante a implantação do programa Educom.rádio sob a responsabilidade do NCE, ou seja, até dezembro de 2004. As relações possíveis de influências nos processos examinados nesta pesquisa e que foram estabelecidas pela Oboré se tornam novo fator a ser levado em consideração quando se percebe que, assim como o mandato do vereador Carlos Neder, esta nutre particular interesse e atuação no setor de Saúde.

Em 2005, o documento com o título Reunião com o Deputado Estadual Carlos Neder, Assembléia Legislativa do Estado de São Paulo, com data de 16 de dezembro, informa que a pauta tratada seria a "implantação do Comitê Gestor do Programa Educom - Educomunicação pelas ondas do rádio (lei municipal $\mathrm{n}^{\mathrm{o}}$ 13.941/04) e estratégia de tomada do programa em 2006”. Essa reunião foi a que preparou o grupo para falar com o Secretário Municipal de 
Educação, José Aristodemo Pinotti, em audiência relatada pelo sítio da Oboré e comentada alguns parágrafos acima. No item Participantes dessa reunião, anuncia o documento que estavam presentes: o deputado Carlos Neder; Marco Manfredini (chefe de gabinete do dep. Carlos Neder); Eduardo Saron (superintendente de Atividades Culturais do Itaú Cultural); prof. Ismar Soares (coordenador do NCE); Margareth Santos (Escritório Modelo D. Paulo Evaristo Arns); Sergio Gomes (diretor da Oboré) e Terlânia Bruno (representante do Sindicato dos Jornalistas no Estado de São Paulo). Na seção Encaminhamentos, pode-se ler que: "A audiência com o Secretario Pinotti, solicitada pelo deputado Carlos Neder durante a reunião, foi marcada para o dia 22 de dezembro, quinta-feira, às 18 horas". Afirma também que o Secretário receberia um documento, "a ser produzido pelo Sergio e pelo Saron”, onde seriam prestadas contas do projeto Onda Cidadã, desenvolvido pelo Itaú Cultural para a capacitação das escolas em 2006. O documento especifica ainda como seriam distribuídas as falas durante reunião com o Secretário: o deputado Carlos Neder falaria sobre a implantação do Comitê Gestor do programa Educom.rádio e apresentaria os nomes e contatos dos integrantes que "já são conhecidos através de levantamento feito pela Oboré”; o prof. Ismar falaria sobre a capacitação das Emefs (Escolas Municipais de Ensino Fundamental) e sobre a metodologia, que ficaria "a cargo do NCE e recursos do Itaú Cultural, que também se dispõe a viabilizar verba para transformar os atuais laboratórios de rádio das escolas em verdadeiras rádios comunitárias"; Eduardo Saron falaria sobre a viabilização do programa e a "capacitação e apoio ao evento sobre o Educom", o qual pretendia dar "visibilidade ao projeto"; Sergio Gomes relataria a situação das rádios comunitárias de São Paulo e sobre o canal 198 destinado a elas. Os encaminhamentos que constam nesse documento apontam ainda que seria feita a solicitação de audiência, sob responsabilidade do deputado Neder, com Ministro das Comunicações "para tratar da questão do canal 198" e termina sugerindo o 
Fórum das rádios comunitárias de São Paulo, com a "idéia de que se estabeleça contato permanente com as emissoras comunitárias".

Em outro documento intitulado Educom.rádio e sua interface com o Onda Cidadã, produzido pela Oboré por encomenda do Instituto Itaú Cultural e "especialmente para a Secretaria Municipal da Educação do Município de São Paulo", datado de março de 2005, é feito um levantamento das escolas que tinham participado da formação promovida pelo programa Educom.rádio entre 2001 e 2004. O documento dá destaque para o fato de que "das 455 escolas que participaram das capacitações, 278 receberam os seus equipamentos de rádio. Desse total, 49 apresentaram resultados acima da média, destacando-se pela maneira com que suas equipes aturaram nas diversas atividades do Educom.rádio". No subtítulo Além dos muros da escola, o primeiro item enumerado diz respeito à possibilidade de as rádios implantadas nas escolas se tornarem rádios comunitárias e que essas são "importantes canais de comunicação com a comunidade, principalmente a mais carente, transmitindo informações de interesse local, nas áreas das políticas públicas - saúde, educação, transporte etc.”. Para reforçar essa idéia de que a rádio da escola pudesse se tornar uma rádio comunitária, o documento faz referência ao fato de que a Anatel (Agência Nacional de Telecomunicações) tornou o canal 198 (freqüência 87,5 a 87,7) disponível para as rádios comunitárias de São Paulo. Diz também que a lei no 13.885 prevê que o Executivo "desenvolva um Plano Diretor de Radiodifusão Comunitária até 2006”. Além de reportar alguns eventos realizados sobre os temas saúde, rádio e educação, o documento apresenta o programa Onda Cidadã: radiodifusão, cultura e educação, promovido pelo Instituto Itaú Cultural. Esse programa teve como um de seus objetivos: "Ampliar a troca de experiências entre os radiodifusores e multiplicar o contato com quem vive rádio de maneira intensa e criativa”. O público-alvo foram "as rádios cidadãs - emissoras preocupadas com o desenvolvimento local sem perder seu caráter nacional". Como "Proposta para 2005", o Onda Cidadã previa: "Ampliar a gama 
de participantes e de atividades, a partir de Encontros e Produção de Conteúdos. A meta é criar uma rede de Rádios Cidadãs parceiras do Instituto Itaú Cultural, em todo o território nacional". O documento também é composto de uma parte denominada Pesquisa: mapeamento e georreferenciamento Educom.rádio. Nessa parte, alguns dados sobre a condição do programa Educom.rádio são apresentados: 455 escolas participaram da capacitação promovida pelo programa; 278 receberam os equipamentos de rádio; dessas, os responsáveis pela pesquisa conseguiram contatar 227 (ou 82\%). No item Escolas que instalaram o equipamento, a pesquisa afirma que 198 escolas responderam ter recebido o equipamento de rádio e que 6 delas comentaram que o receberam incompleto, enquanto 28 não receberam. Dentre as escolas que responderam ter recebido o equipamento, 121 informaram que "o equipamento de rádio está funcionando" e 77 disseram que não está funcionando, sendo que a maior parte dessas (36) disse apenas que está parado. O documento é ilustrado com mapas dos bairros/coordenadorias onde estão localizadas as escolas investigadas por essa pesquisa.

No item Documentos de referência, há um documento com o título Registro de reunião com Secretaria Municipal de Educação, 16 de março de 2005, com o subtítulo Depoimento Professor José Aristodemo Pinotti, Secretário da Educação. Nele, o Secretário começa afirmando que: "Fui agradavelmente surpreendido pela visita de alguém que veio aqui propor, rapidamente, sem assinatura e sem financiamento da SME, desenterrar um projeto que está semi-adormecido em $80 \%$ de nossas escolas”. E continua, dizendo que:

É preciso oxigenar esse ensino, integrar a comunidade. E o que vocês estão propondo é uma boa ajuda no processo de oxigenação do ensino e de integração da comunidade. [...] Nós não podemos gastar dinheiro, porque não tem. [...] $\mathrm{O}$ fato de vocês oferecerem uma ajuda da magnitude que vocês estão oferecendo, dentro dos nossos projetos prioritários e sem custo ou pelo menos com custo muito pequeno, para a gente é uma coisa muito boa, portanto, está mais do que aceita. E mais do que isso, o fato de começar a trabalhar antes de tirar fotografia e antes de assinar convênio é uma coisa que me agrada profundamente. (OBORÉ, 2005). 
A atuação da Oboré propondo essa interface marca nitidamente sua presença na disputa pela continuidade do programa Educom.rádio. Por meio de uma relação entre o órgão público, a Secretaria Municipal de Educação de São Paulo e as entidades privadas Oboré e o Instituto Itaú Cultural, é realizada a proposta de trabalho sem custo para a Secretaria (os gastos com o programa seriam pagos pelo Instituto Itaú Cultural). O Secretário salienta esse aspecto ao aceitar a proposta. Assim, o projeto Onda Cidadã, fruto da parceria entre a empresa e o instituto, usaria a estrutura criada pela implantação do programa Educom.rádio para desenvolver suas atividades, organizadas agora sob a responsabilidade daquelas parceiras.

Entretanto, essa forma de implantação, ou de interface entre os projetos-programas, não se efetivará.

\subsection{O DECRETO}

Nesse rol de fatores e providências que concorreram para que se efetivasse o que estamos considerando como continuidade do programa Educom.rádio, foi assinado pelo prefeito José Serra o Decreto no 46.211, publicado no Diário Oficial de São Paulo em 15 de agosto de 2005. Esse decreto regulamenta o Programa Educom - Educomunicação pelas ondas do rádio. A partir de então, o programa foi retomado em caráter oficial.

Como a lei previa, esse decreto dispõe, em seu artigo $8^{\circ}$, sobre a composição e competências específicas do Comitê Gestor, o qual ficaria “encarregado da implantação e implementação do programa de que trata este decreto" e seria constituído "no âmbito da Prefeitura do Município de São Paulo e vinculado à Secretaria Municipal de Educação". O parágrafo $1^{\circ}$ desse artigo conforma as instituições que contariam com integrantes no Comitê:

I - Secretaria Municipal de Educação;

II - Secretaria Municipal da Saúde; 
III - Secretaria Municipal de Cultura;
IV - Secretaria Municipal de Esportes, Lazer e Recreação;
V - Secretaria Municipal do Verde e do Meio Ambiente;

VI - instituições de ensino superior com experiência em docência e pesquisa na área de educomunicação;

VII - grêmios estudantis das escolas municipais;

VIII - professores da Rede Pública Municipal de Ensino;

IX - Sindicato dos Jornalistas;

X - Sindicato dos Radialistas;

XI - entidades voltadas ao desenvolvimento da prática da comunicação educativa.

Chama atenção novamente o fato de que o único grupo a sofrer alguma restrição para participar do Comitê é o "das instituições de ensino superior com experiência em docência e pesquisa na área de educomunicação", como no texto da lei.

Quanto às pessoas responsáveis pela implantação, o Artigo $9^{\circ}$ diz que seria competência do Comitê Gestor:

I - definir diretrizes gerais para a implantação e implementação do programa; II - sugerir ações educomunicativas a serem promovidas pelas Secretarias e órgãos municipais;

III - credenciar instituições prestadoras de serviço ou universidades candidatas às ações de formação;

IV - acompanhar e avaliar os programas desenvolvidos pelas Secretarias e órgãos municipais, objetivando seu redimensionamento;

V - estabelecer contatos com a Agência Nacional de Telecomunicações ANATEL, a fim de viabilizar o desenvolvimento do programa.

Define, no Artigo $2^{\circ}$, a educomunicação como sendo: “a inter-relação entre processos e tecnologias da informação e da comunicação e as demais áreas do conhecimento e da vida 
social, ampliando as habilidades e competências e envolvendo diversas linguagens e formas de expressão para a construção da cidadania”.

O Artigo $6^{\circ}$ incumbe a Secretaria Municipal de Educação de:

I - assegurar o equipamento de produção e transmissão radiofônica às escolas municipais já beneficiadas pelo programa em desenvolvimento;

II - ampliar, gradativamente, o número de escolas envolvidas no programa, abrangendo os membros da comunidade escolar e do entorno, inclusive os diretores, coordenadores pedagógicos, professores, servidores, alunos e exalunos;

III - assegurar a manutenção do equipamento que produz e transmite os programas radiofônicos nas escolas municipais já beneficiadas e nas que virão a fazer parte do programa;

IV - promover, por meio da Diretoria de Orientação Técnica da Secretaria Municipal de Educação, cursos de formação inicial e continuada a todos os envolvidos;

V - acompanhar e avaliar, por intermédio das Coordenadorias de Educação, as atividades desenvolvidas no programa.

O Artigo $5^{\circ}$ especifica o desenvolvimento do programa na Secretaria Municipal de Educação, o qual deveria ser, "nas unidades educacionais, articulado ao seu projeto pedagógico, na perspectiva de se instalar uma rede de comunicação que estimule a utilização de diferentes linguagens, em especial a radiofônica, na formação da competência comunicativa e da construção da leitura e da escrita". Ainda nesse artigo, em parágrafo único, o programa Educom.rádio passa a integrar as ações previstas por um programa do novo governo: o Programa São Paulo é uma Escola. Esse programa consistia em atividades de "caráter educacional, cultural, social e esportivo, além do período regular de aulas, inseridas em horários pré e pós-escola, nos finais de semanas, feriados, recessos e férias escolares" oferecidas aos estudantes. Desse programa fariam parte ainda outros, dentre os quais: Recreio nas Férias, Programa de Prevenção da Violência nas Escolas, Programa Agita Sampa, Projeto Escotismo, Projetos de Educação Sexual, Projetos de Ensino Bilíngüe e Projeto Xadrez - 
Movimento Educativo. Além de ter um formato parecido com o que tinha sido o Projeto Vida (um projeto que agregava variadas ações implementadas nas escolas), arregimentou alguns de seus programas (o caso do programa Educom.rádio) e até mesmo a sua razão de existir, contida no Programa de Prevenção da Violência nas Escolas.

Esse é o decreto em que o novo governo anuncia a continuidade do programa Educom.rádio. Institui o programa em caráter permanente. No entanto, introduz algumas mudanças: o decreto não faz menção de que o programa incentive a "cultura de paz" ou que encaminhe respostas para o problema da violência nas escolas, como até então vinha sendo defendido. Considera que o programa promoveria a "formação da competência comunicativa e da construção da leitura e da escrita". Deixa a cargo da Diretoria de Orientação Técnica da Secretaria Municipal de Educação a promoção de cursos de formação inicial e continuada para todos os envolvidos no programa.

\subsection{O COMITÊ GESTOR}

Em 22 de dezembro de 2005, é publicada no Diário Oficial da Cidade de São Paulo a Portaria 8083, de 21 de dezembro de 2005, a qual constitui o Comitê Gestor que ficaria encarregado da implantação e implementação do programa Educom - Educomunicação pelas ondas do rádio no âmbito da Prefeitura do Município de São Paulo e vinculado à Secretaria Municipal de Educação. Essa portaria designa ainda, para integrar o Comitê, os seguintes representantes de instituições (SÃO PAULO, 2005b):

Secretaria Municipal de Educação

Titular: Jarbas Mazzariello, RF 318.006.9.02

Suplente: Regina Célia Lico Suzuki, RF 137.416.8.00

Secretaria Municipal da Saúde

Titular: Simone Sayuri Kobayashi Hanada, RF

748.263.9.00

Suplente: Keila Cristina Silva, RG 30.578.133-9

Secretaria Municipal de Cultura

Titular: Rita Aparecida Daher Lorenzato, RF 
544.950.2.01

Suplente: Marco Antonio Alonso Ferreira, RF

742.426.4.00

Secretaria Municipal de Esportes, Lazer e Recreação

Titular: Patrick Renzi de Araújo, RF 749.541.2.00

Suplente: Lais Helena Malaco, RF 526.830.3.02

Secretaria Municipal do Verde e do Meio Ambiente

Titular: André Luiz Moura de Alcântara, RF 648.192.2.00

Suplente: Mara Eliana Tosin, RF 549.427.3.00

Instituição de Ensino Superior

Titular: Prof. Dr. Ismar de Oliveira Soares

Suplente: Luiz Marcello de Menezes Bittencourt

Grêmios Estudantis de EMEF

Titular: Thiago Souza de Lima - EMEF Prof. Carlos Pasquale

- CE São Miguel

Suplente: Lais de Souza Costa - EMEF Prof. Carlos Pasquale

- CE São Miguel

Professores da rede

Titular: Carlos Alberto Mendes de Lima, RF 724.836.9.00

- EMEF Pedro Teixeira - CE São Miguel

Suplente: Rosemeire Batista Gimenes De Araujo, RF

607.505.1.01 - EMEF Antonio Carlos de Andrade e Silva

Sindicato dos Radialistas

Titular: Edson Amaral

Suplente: Sérgio Ipoldo Guimarães

Entidades voltadas à comunicação educativa

Titular: Izabela Ottoni de Santa Martha Piquet, RG

5.562.406 (SSP/MG)

Suplente: Marco Santoro, RG 28.310.167-2 (SSP/SP)

Conforme a ata de reunião desse Comitê Gestor, a sua primeira reunião foi realizada em 3 de março de 2006. Nessa ata, há a declaração de que “o Secretário lembrou que sua pasta, após um período de avaliações, havia constado que o programa necessitava ser retomado, para garantir na escola pública o que se oferece na escola privada". E mais adiante: "o Secretário lembrou o trabalho realizado pela equipe da DOT, em 2005, tanto na manutenção do projeto quanto nos estudos que permitiram à Secretaria ter uma visão mais ampla sobre o estado do Educom". O Secretário cogita a possibilidade de "ter condições de montar umas 20 rádios comunitárias em nossa rede de ensino". Finaliza sua fala, de acordo com a ata, reafirmando a 
responsabilidade dos integrantes do Comitê: “A tarefa de vocês será muito importante no sentido de encontrar caminhos e soluções que garantam a continuidade e o avanço do projeto na Secretaria e nas comunidades escolares" (SÃO PAULO, 2006, p. 7).

Essa ata chegou à mira desta pesquisa por meio do acervo de documentos existentes na sala do gabinete do vereador Carlos Neder na Câmara Municipal de São Paulo. A primeira reunião, à qual a ata remete, foi realizada na Secretaria Municipal de Educação. Anexado à ata, há um ofício assinado pelo deputado Carlos Neder, em papel timbrado e com cabeçalho da Assembléia Legislativa do Estado de São Paulo, endereçado ao Secretário da Educação do Município de São Paulo, José Aristodemo Pinotti, com data de 8 de março de 2006, onde se pode ler: "Sirvo-me do presente para solicitar a Vossa Excelência o envio da Ata da primeira reunião do Conselho Gestor do Programa Educom. 'Educomunicação nas Ondas do Rádio', realizada no dia 3 de março”. O ofício em resposta, também anexado, assinado pelo Secretário Municipal de Educação, José Aristodemo Pinotti, é enviado em 29 de março de 2006. Nele, o Secretário diz: “envio a Ata da Primeira Reunião do Conselho Gestor do Programa Educom ‘Educomunicação nas Ondas do Rádio', realizada aos três de março do corrente”.

Decorre daí que as informações a respeito da fala do Secretário são fidedignas, uma vez que foi ele quem as enviou ao deputado. A ata é assinada pelos funcionários responsáveis pelo programa Educom.rádio na Secretaria Municipal de Educação: Carlos Alberto Mendes de Lima e Jarbas Mazzariello. O programa não seguiu sendo implantado pelo NCE depois de 2004, ainda que Ismar de Oliveira Soares, coordenador daquele Núcleo, faça parte do Comitê Gestor do programa. 


\subsection{A DIRETORIA DE ORIENTAÇÃO TÉCNICA}

Subjacente às práticas e intenções descritas até aqui, no início de 2005, o programa aparece como uma das propostas de formação anunciadas pela Divisão de Orientação Técnica do Ensino Fundamental e Médio para serem realizadas junto a Coordenadorias e escolas, com intuito de compor as:

[...] ações [que] serão desencadeadas visando o fortalecimento da Gestão Pedagógica das escolas, porém, neste momento, estamos elegendo o desenvolvimento da competência leitora e escritora no Ciclo II, acreditando que as demais ações, como o EDUCOM e o Mão na Massa, possam também contribuir para o fortalecimento desta gestão e da aprendizagem dos alunos. (SÃO PAULO, 2005, p. 30).

No item C dessas propostas de formação, o programa é denominado Nas Ondas do Rádio -

Educom.com. O público-alvo seria a "DOT Equipes das Coordenadorias de Educação, coordenadores pedagógicos das escolas e alunos". Os docentes não aparecem mais como alvos das atividades previstas pelo programa. No item Estrutura e Funcionamento, são anunciadas como medidas: "Reuniões no $1^{\circ}$ semestre de 2005 com os supervisores e ou técnicos que acompanham o projeto nas Coordenadorias" (SÃO PAULO, 2005, p. 35). Como objetivos, o programa procurava:

Planejar ação de formação em parceria com as equipes das Coordenadorias e escolas e de acordo com o projeto às diretrizes da SME - como o projeto contribuirá no processo ensino aprendizagem no que diz respeito ao desenvolvimento das competências - oralidade, leitura e escrita; Formar as escolas que ainda não iniciaram o projeto, possuem o equipamento $\mathrm{e}$ desejam desenvolvê-lo. (SÃO PAULO, 2005, p. 34).

Ainda como justificativa para essa proposta de formação da DOT, o documento afirma que:

Daremos continuidade ao projeto, potencializando o uso do equipamento para atender às demandas que envolvem o protagonismo dos alunos e o desenvolvimento da linguagem radiofônica com o objetivo de ser mais um 
aliado para o desenvolvimento da competência escritora, leitora e oralidade das crianças, adolescentes e jovens. (SÃO PAULO, 2005, p. 34).

Mesmo com a mudança de nome e reorientação de objetivos, os procedimentos relativos ao programa foram sugeridos de forma a dar continuidade por meio de ações da DOT. Essas ações foram fazendo com que o programa permanecesse no novo governo ainda que não tenha havido decisão oficial do Secretário a respeito.

Talvez como característica da especialização da organização administrativa da Secretaria Municipal de Educação do Município de São Paulo, por motivo também de continuidade de cargos mesmo no novo arranjo do governo, tenha havido a delegação de tarefas a determinadas partes da organização, ou seja, na troca da hierarquia superior, as outras seguiram momentaneamente suas atividades, como atributos da especialização das funções decisórias entre membros da hierarquia que seguiram a rotina burocrática.

Essas decisões (de continuar o programa como ação da DOT) podem parecer, num primeiro golpe de vista, apenas proposições factuais por se configurarem como propostas de formação, feitas por um dos órgãos responsáveis em orientar práticas em relação à rede de escolas públicas. No entanto, elas podem ser entendidas também como um prenúncio de "futuro estado de coisas". Adquirem aí, no planejamento da DOT, uma qualidade imperativa, porque foram selecionadas em detrimento de outras e orientam o comportamento rumo à alternativa escolhida (SIMON, 1965 p. 54).

Essa transferência do programa para a DOT merece ser apreciada em detalhes, uma vez que se configura como um dos motivos de o programa aparecer, no começo do novo governo, como uma das ações propostas por essa Diretoria, mesmo sem um aval oficial do novo Secretário. 
Claudemir Viana (2007), coordenador pedagógico do programa Educom.rádio entre 20032004, ligado ao NCE, sugere que o ano de 2004 (sexta e sétima fases) foi o melhor do programa sob a responsabilidade do NCE. Os motivos apontados por ele foram que o programa saía da esfera de ação do Projeto Vida e passava a integrar propostas da DOT. Com isso, o programa teria sido "absorvido, na Secretaria Municipal de Educação, como parte do programa curricular. Não se tornando uma disciplina, mas se tornando obrigatória a sua aplicação de alguma maneira nas escolas municipais". (Informação pessoal) ${ }^{35}$. O coordenador afirma ainda que contribuiu para o que considera essa melhoria, "em termos de qualidade e de repercussão", o fato de que estávamos em ano eleitoral. No governo Marta, a Secretaria deu todo apoio para divulgar os resultados
do Educom. Até porque, como estratégia, no sentido de dar o máximo de
divulgação possível aos bons resultados da intervenção do Educom.rádio nas
escolas. Então, dá-lhe chamar aluno para participar de simpósio, para fazer
simpósio, para colocar isso no boletim, fazer isso aparecer de alguma
maneira na mídia, que é para dar transparência a um projeto que tinha a
dimensão como tinha. Então, em termos políticos, o sexto e o sétimo módulo
receberam muito respaldo da Secretaria Municipal de Educação e do
governo Marta como um todo. (Informação pessoal)

Essa atividade de divulgação dos resultados e visibilidade alcançada parece ter outro sentido, muito mais do que o simples fato de dar transparência ao processo. Revela também a intenção de uso do programa como marketing, almejando, talvez, a continuidade do governo de Marta Suplicy tanto quanto uma possível troca de favores, com vista à continuidade do programa sob a responsabilidade do NCE.

Viana (2007) afirma também que a mudança de órgão responsável pelo programa dentro da Secretaria, do Projeto Vida para a DOT, foi uma determinação diretamente influenciada pelo NCE: "Tanto é que o Ismar e a Patrícia usaram como estratégia conversar muito com o pessoal da DOT. Foi até meio que uma consequiência o Educom.rádio ter saído do Projeto

\footnotetext{
${ }^{35}$ VIANA, C. Entrevista concedida a Mauro Soares Cordeiro em 30 de out. de 2007.

${ }^{36}$ Ibid.
} 
Vida e ter ido para a DOT. A DOT é algo muito mais institucionalizado, muito mais amplo, do que pontual como o Projeto Vida".

Viana (2007) considera a aprovação da lei como vitória política, e justifica dizendo que o programa começou como um dos programas do Projeto Vida, "bem pontual, para chegar a se tornar uma lei municipal". Viana associa a aprovação da lei com o fato de o programa ter sido transferido para a DOT.

No finzinho, o Educom.rádio saiu do Projeto Vida e foi para a DOT. Ou seja, ele deixou de estar em um núcleo bem menor, que era uma proposta muito pontual, de atuação contra a violência, e passou a fazer parte das estratégias curriculares. Em termos práticos, o que significou foi que o Educom.rádio deixou de ser uma coisa pontual e isolada, [...] para [fazer parte de] um outro departamento, que é a DOT, diretamente envolvido com a questão curricular. Tanto é que foi nesse ano que a lei municipal do Educom foi sancionada, foi aprovada pela Câmara Municipal. A lei foi assinada pelo José Serra em 2005. Mas a lei foi aprovada pela Câmara Municipal justamente em 2004. (Informação pessoal) ${ }^{37}$.

Marívia Torelli (2008), diretora da DOT entre 2002 e 2004, afirma que o fato de o programa Educom.rádio ter começado a fazer parte das ações previstas pela DOT foi porque existia a intenção de articular diferentes projetos para que se constituíssem como currículo nas escolas e que não ficassem apenas "como algo apartado como um projeto especial". A idéia era a de "que o Educom.rádio tivesse um diálogo dentro da unidade com as áreas do conhecimento para quebrar com essa visão tradicional, conservadora, de formato de aula quadradinho". (Informação pessoal) $^{38}$. Outro fator apontado por Torelli (2008) como de interesse para os planos da DOT era que:

O projeto Educom.rádio e o Projeto Vida investiam diretamente na questão da gestão democrática da escola. O Educom.rádio foi o tempo todo um exercício de gestão, porque envolvia professores, a gestão da escola, a comunidade e as crianças. Até na hora de você montar a pauta. Que a pauta era de todos, tinha de se discutir para chegar à pauta de programação. Era

\footnotetext{
${ }^{37}$ Ibid.

${ }^{38}$ TORELLI, M. Entrevista concedida a Mauro Soares Cordeiro em 28 de fev. 2008.
} 
uma decisão de todos. E a gente queria esse olhar para trabalhar com currículo. (Informação pessoal) ${ }^{39}$.

Torelli (2008) informou que houve conversas com o coordenador do Projeto Vida, a partir de 2003, Matias Vieira, para estudar a possibilidade de "trazer o Projeto Vida como um todo para a DOT". Contou também que, para se resolver por essa transferência, foi consultada a Secretária Municipal de Educação, Cida Perez. Mas que, no caso específico do programa Educom.rádio, essa transferência foi sugerida a partir de conversas com Ismar de Oliveira Soares: "Ele chegou a conversar comigo sobre isso, me procurar". No fim de 2003, o programa Educom.rádio foi em definitivo para a DOT e, em 2004, “já foi um trabalho conjunto DOT-programa Educom.rádio”.

Mesmo admitindo ter sofrido a influência do coordenador do NCE, Torelli via a relação estabelecida como troca: o programa saía da responsabilidade do Projeto Vida e passava a atender aos desígnios da DOT. Para resolver por trabalhar com o programa, em parceria com o NCE, acreditava que o Educom.rádio representava a possibilidade de "trazer a comunidade para pensar sobre o currículo. Como fazer esse diálogo? O Educom era essa possibilidade”. A diretora afirma ainda que, com as ações da DOT, o Projeto Vida também foi sendo “aproximado do trabalho pedagógico stricto sensu, porque ele não necessariamente envolvia a questão ensino-aprendizagem, antes. A gente trouxe para dentro da DOT para isso, para que isso acontecesse". (Informação pessoal) ${ }^{40}$.

O coordenador do Projeto Vida (2008), Matias Vieira, que o assumiu após a saída de Dirce Gomes em 2003, confirma que havia a intenção de as ações desenvolvidas por esse projeto virem a integrar a formação proposta pela DOT e observa que:

\footnotetext{
${ }^{39}$ Ibid.

${ }^{40}$ Ibid.
} 
Quando fui para o Projeto Vida, pensei estendê-lo para a parte pedagógica da escola, que era discutir a formação do professor e a formação feita por DOT dentro desse olhar de "Cidade Educadora", que nós começamos a defender, e dentro desse olhar mais amplo de ressignificação do espaço escolar. E aí mexe com currículo, com professor em sala de aula e tal. Então, quando saí do Projeto Vida, ele já estava sendo encaminhado para a Diretoria de Programas, que foi constituída nessa administração, e integrar cada vez mais a questão das ações do Projeto Vida com o pedagógico. Na minha ausência [quando deixou a Secretaria em 2004], quem assumiu foi a Marívia, que era a diretora de DOT. O Projeto Vida entrou dentro de DOT. DOT começou a assumir o Projeto Vida. (Informação pessoal) ${ }^{41}$.

Decorre daí a intenção de integração do Projeto Vida às "práticas pedagógicas da escola" via DOT. Com isso, o programa Educom.rádio também foi transferido para não ser "uma coisa à parte" e para que fizesse parte da "ação pedagógica da escola":

A escola está muito presa ao livro didático, ao espaço da sala de aula. Qualquer outro equipamento tecnológico que chega até ela, não é facilmente incorporado à prática pedagógica. Se você pegar a sala de informática, por exemplo, ainda poucos professores utilizam esse meio como uma forma de avançar a aprendizagem da criança, pela própria dificuldade que ele tem de utilizar esse equipamento. No Educom, estávamos vivendo a mesma fase: entrar na escola, vencer a resistência de que ele representa barulho, só faz barulho na escola (quando mal utilizado, não é?), representa o questionamento das relações hierárquicas dentro da escola. Nós entendemos que não devia ser uma coisa à parte da escola, ele tinha de integrar a ação pedagógica da escola. Aí, esse movimento que fiz de sair, também, já tinha um pouco essa perspectiva: de que DOT assumisse as ações do Projeto Vida como um repensar o pedagógico no currículo da escola. (Informação

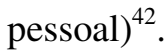

Vieira (2008) afirma ainda que as ações e intenções praticadas pela administração da Secretaria Municipal de Educação foram no sentido de "criar a necessidade de a escola querer aceitar o projeto, de encampá-lo":

Então, você pega o Educom.rádio, que era para uma escola e nós levamos para 455 escolas de ensino fundamental da época e com formação gradativa. Começamos em 2001 para chegar em 2004 com todas as escolas. Garantindo a questão da formação dos professores para que o projeto pudesse ter incorporação dentro do espaço escolar. Então, nós vínhamos num avanço, na perspectiva de consolidar os projetos, mas também tentando amarrar isso

\footnotetext{
${ }^{41}$ VIEIRA, M. Entrevista concedida a Mauro Soares Cordeiro em 21 de fev. 2008.

${ }^{42}$ Ibid.
} 
com a discussão pedagógica que era: uma cidade educadora. São Paulo, uma cidade educadora. E a questão do CEU. O CEU, ele potencializava todas as ações do [Projeto] Vida de forma mais qualificada possível. Além do que: o Educom ia ter uma ilha de produção, que a escola muitas vezes não teria. $\mathrm{O}$ nosso caminhar, era um caminhar no sentido de manter isso como um programa de continuidade, com perspectiva de atender todas as escolas de Ensino Fundamental, uma ferramenta a mais de trabalho, como é o laboratório de informática, por exemplo, a sala de leitura, hoje, na rede municipal. (Informação pessoal) ${ }^{43}$.

Nota-se que Vieira explica, nesse excerto, também a intenção de mudança de objetivo do programa, que passaria a ser mais uma "ferramenta de trabalho" para ser usado nas escolas de ensino fundamental.

Também Soares (2008) credita o fato de o programa ter sido transferido para a responsabilidade da DOT à prefeitura, pois esta:

[...] entendeu que ele era curricular. Ele incidia na política educacional. E a prefeitura já vinha trabalhando a questão da gestão escolar. E a Marívia, ela fez Educom como professora e uma filha dela também fez, e ela entendeu que existia uma essencialidade no Educom que era a gestão da comunicação no espaço escolar e que aquilo era currículo. $O$ projeto, então, sai do [Projeto] Vida e vai para DOT. (Informação pessoal) ${ }^{44}$.

Perguntado se havia sido chamado para decidir sobre a ida do programa para a DOT, Soares diz que não houve o convite. No entanto, afirma que o contato com esse setor se deu pela ventura de ser chamado para participar da formação dada pela Secretaria aos POIEs (Professores Orientadores de Informática Educativa), no primeiro semestre de 2004. A DOT contava como uma área voltada à informática educativa, que respondia pela formação específica desses profissionais.

Então, o POIE era alguém da informática educativa e a Marívia entendeu que os POIEs tinham de agir educomunicativamente. Quer dizer, não houve nenhum decreto, a prefeitura me chama para participar da reunião com os POIEs, juntamente com assessoria que a Secretaria tinha, dada pela Poli

\footnotetext{
43 Ibid.

${ }^{44}$ SOARES, I. Entrevista concedida a Mauro Soares Cordeiro em 26 de ago. 2008.
} 
[Escola Politécnica da USP]. A Poli dava uma assessoria na área da informática. Daí, ela chama o NCE para conversar com os POIEs sobre a gestão democrática da comunicação. Eu fui falar com os POIEs sobre Educom.rádio. Isso se deu em 2004, primeiro semestre e, no segundo semestre, o Educom já foi levado para a DOT. (Informação pessoal) ${ }^{45}$.

Soares (2008) vê o fato de o programa ter sido incorporado dentro da filosofia de trabalho da prefeitura como uma vitória em termos ideológicos, em termos de paradigma, para o Educom e sua missão. Entretanto, supõe também que a transferência representou um enfraquecimento, simultaneamente. (Informação pessoal) ${ }^{46}$ :

O Educom se firma enquanto proposta, é reconhecido enquanto proposta pedagógica, é inserida na proposta pedagógica [da DOT]. Termina o mandato e a Marta não é reeleita... Segundo prejuízo: como projeto especial [ligado ao Projeto Vida], existia uma verba. Uma vez que o projeto deu certo, existia uma dotação de verba e era administrada por um setor específico. Quando o projeto Educom sai desse setor específico [ligado ao Projeto Vida] e entra no rol da constitucionalidade da Secretaria, não vai existir mais uma verba específica.

A verba destinada ao programa, com a mudança para a DOT, seria vinculada à dotação orçamentária da Secretaria. Antes, o programa tinha verba prevista aos projetos, ações e programas sob a responsabilidade do Projeto Vida. Essa mudança de setores e, conseqüentemente, de fonte financiadora acarretou alguns entraves ao programa como, e sobretudo, o atraso do pagamento aos serviços prestados pelo NCE:

Nós sabíamos que viria o pagamento, porém, ele dependia da liberação da Secretaria da Fazenda. O que exigia a prestação de contas daquele período, o relatório tinha de passar por muitas comissões até ser protocolado e, aí, entrar no calendário da Secretaria de Educação. O que sempre deixava a gente numa situação de tensão, porque nós só podíamos mandar o relatório no dia seguinte ao término do mês. Bom, terminou o mês você vai mandar isso. Só que a prefeitura demorava 2 a 3 meses para aceitar e aprovar e pagar... As pessoas que trabalhavam recebiam sempre com 3 meses, 4 meses de atraso... Quem estava necessitado sentia-se inseguro. Finalmente, a grande desgraça para todos nós foi o fato de a própria prefeitura não ter pago a partir da metade do primeiro semestre de 2004. O que foi feito até maio foi

${ }^{45}$ Ibid.
${ }^{46}$ Ibid. 
pago, o que foi feito a partir de maio até o final não foi pago. Foi uma dívida que foi deixada para a nova administração. (Informação pessoal) ${ }^{47}$.

Somado ao fato de o programa passar por esse apuro financeiro causado pelo atraso do pagamento ao Núcleo responsável pela implantação, com a mudança de governo a partir de 2005, o programa também é submetido a um demorado período de avaliação:

Quando a nova gestão do Serra aparece, o Educom é um dos projetos. Não tinha aquela carga política e emocional. Ele passou a mais um projeto e tinha de ser avaliado. Aí, o Serra vai demorar com esse processo de avaliação e aí perde-se o vigor do projeto... (Informação pessoal) ${ }^{48}$.

Soares (2008) assegura que a relação entre o NCE e os Secretários Municipais de Educação, durante o governo do PT, nunca teve problemas. Estes sempre se mostraram pré-dispostos à continuidade do programa:

No início, foi o dr. Fernando de Almeida que foi o que teve a coragem de assumir. Ele é um professor da PUC, ele foi o responsável [por aceitar o programa]. Mas ele não continua, ficou um ano só. Depois dele veio uma professora chamada Maia, irmã do César Maia, do Rio de Janeiro. Ela apoiou o projeto, participou de várias ações. Depois, veio a Cida Perez e deu continuidade. (Informação pessoal) ${ }^{49}$.

No entanto, lembra que essas mudanças de cargo de Secretário demandavam novos esforços por parte do NCE:

A relação com o poder público foi uma relação sempre difícil. Não por falta de cordialidade. Pessoas cordatas, pessoas animadas, mas pelo fato de que cada nova autoridade que chegava necessitava ser convencida de que o projeto era bom. Eles herdavam o contrato que já tinha sido feito. Muito complexo, envolvia muitas pessoas. Então, eles necessitavam ficar por dentro. Isso sempre demorava... (Informação pessoal) ${ }^{50}$.

\footnotetext{
${ }^{47}$ Ibid.

48 Ibid.

${ }^{49}$ Ibid.

${ }^{50}$ Ibid.
} 
6.6 A CONTINUIDADE DO PROGRAMA ENTRE 2006 E 2008

Carlos Lima (2008), professor da rede municipal de educação pública, que, desde a primeira reunião do Comitê Gestor em 2006, tornou-se também o coordenador do programa na Secretaria Municipal de Educação, acredita que o fato de o programa ter continuado está ligado à importância que este tem para o jovem. Supõe também que: "essa gestão acabou acreditando nessa vocação de o projeto ser muito ligado ao jovem e à criança. Independente de ter sido lei" (Informação pessoal) ${ }^{51}$. Outro fator apontado pelo coordenador como importante para o programa adquirir continuidade foi:

[...] vir para a DOT, Diretoria de Orientação Técnica, trabalhando a questão pedagógica da escola. Ele poderia ter ido para Programas Especiais e virar um projeto de ação ali. Se estava funcionando legal ou não, eu não sei. Mas ia ficar o projeto ali. Mas é um mérito muito grande para o projeto estar entrando em DOT.

Lima (2008) afirma que o desenvolvimento do programa é incentivado porque "DOT consegue ver que não é só o livro, o texto escrito, que tem importância para a educação. As novas tecnologias e a comunicação são tão importantes quanto. Então, só por isso acho que a DOT acabou pegando, abraçando a gente, levando no colo mesmo" (Informação pessoal) ${ }^{52}$.

No entanto, mesmo passados sete anos desde o início da implantação do programa, acrescentando que passou pela mudança de governos, Lima (2008) supõe que o programa ainda corre risco de descontinuidade. Esse risco decorre da falta de compreensão por parte das pessoas sobre o novo formato que o programa conforma:

[...] não teve uma descontinuidade, muito embora tenha a condição aí, que eu sinto como gestor do programa, que as pessoas ainda não acreditam que esse novo formato do projeto, mais moderno, mais leve, mais interativo, mais fácil de as pessoas adquirirem, que é usando a informática, o computador

\footnotetext{
${ }^{51}$ LIMA, C. Entrevista concedida a Mauro Soares Cordeiro em 8 de set. 2008.

${ }^{52}$ Ibid.
} 
como plataforma de produção midiática, parece que as pessoas enxergam como informática educativa. E não é. (Informação pessoal) ${ }^{53}$.

Sobre as mudanças que o programa sofreu por decisão de Lima, ele afirma, encontraram justificativa porque consideraram os fatores a seguir: das 255 escolas que tinham equipamentos de rádio previstos pelo programa, apenas 50 estavam funcionando no início de 2006; além de possibilitar o acesso de estudantes ao equipamento, seria preciso capacitar docentes para utilizar o equipamento; algumas escolas mantiveram os equipamentos guardados, ou não sabiam como reparar os avariados ou não dispunham de recursos para pagar consertos; as ações com rádio não encontraram apoio entre muitos profissionais de escolas ("Esses meninos fazem muito barulho, só põem músicas”); não há mais no mercado o equipamento para as 200 escolas que faltam; há escolas que passaram por reforma e o lugar em que funcionava o estúdio de rádio teve de ser desocupado.

Somado a esses fatores, Lima (2008) sugere também que o programa perdeu o caráter prioritário que tinha no governo anterior: "O projeto, que tinha lá um espaço de prioridade, passou a ter menor, porque havia outros projetos. O Educom era outro projeto [...]. Tem de se priorizar as coisas que são mais importantes". (Informação pessoal $)^{54}$.

Com essas perspectivas, Lima (2008) concluiu que o programa precisava mudar. Decidiu que: "Precisava ter um alcance que contaminasse o professor" e também que o programa:

Tinha de ter uma acessibilidade para o aluno, mas, também para o professor, porque, aí, eu ia ganhar parceiros dentro da escola. Aí, quando vi aquele programinha [o software Audacity] funcionando, aquilo não me saía da cabeça. Pensava: "Tem uns 20 computadores nas escolas, por que o POIE não usava aquilo?". Aí, fiz um trabalho de experimentação: Vamos chamar alguns POIEs e vamos apresentar. Os caras abriram aquele sorriso, o olho brilhou! Falei: "Ganhei um parceiro". Aí, abri as portas da esperança. Porque a informática sempre teve muito problema de você ter uma conexão que as pessoas fazem da informática com o próprio pedagógico. Fica uma espécie

${ }^{53}$ Ibid.

${ }^{54}$ Ibid. 
de cumbuca isolada. Isso acontece na escola: professor de história não conversa com o professor de português... E aí a informática a mesma coisa. Quis trazer um parceiro para trabalhar com o aluno, mas, ao mesmo tempo, vislumbrando a possibilidade de trabalhar com história, com português... Esse era o grande sonho. Aí, comecei uma grande formação na rede. (Informação pessoal) ${ }^{55}$.

Essa operação de mudança no programa se deu única e exclusivamente por vontade de Lima. Nesta pesquisa, não foi encontrado nenhum dado ou documento em que pudesse haver alguma indicação de participação de outro funcionário ou diretriz que compusesse a Secretaria Municipal de Educação para tal decisão. Lima (2008) assume ainda que, ao ingressar na coordenação em 2006, o programa já era chamado de Nas ondas do rádio:

Quando cheguei aqui, as coisas já estavam dessa forma. Agora, quanto à metodologia de ação, aí eu digo que tive toda a culpa do mundo! Toda culpa do mundo. Desde chamar os caras da informática, para tentar desenvolver esse projeto lá nos pólos. (Informação pessoal) ${ }^{56}$.

Ainda sobre o procedimento metodológico do programa, a educomunicação aparece como componente anunciado como eficaz para se trabalhar o conteúdo e a forma dos dispositivos da comunicação em ambientes educativos. Lima (2008) compreende essa idéia nos seguintes termos:

Não sei se posso chamar isso de rótulo, eu não acredito dessa forma, mas... Tem pesquisador que não fala em educomunicação, fala outra coisa... Não importa, o que vale, na verdade, é você desenvolver um trabalho educativo trabalhando com essas mídias. Aí eu acho que se o cara conseguir entender dessa forma, que eu possa trabalhar, educar através desse uso das linguagens, acho que funciona bem para o pedagógico. (Informação pessoal $^{57}$.

E complementa essa definição dizendo que:

\footnotetext{
${ }^{55}$ Ibid.

${ }^{56}$ Ibid

${ }^{57}$ Ibid.
} 
Um outro lado também é que [a educomunicação] dá uma identidade a essa idéia de educação com comunicação. Toda pessoa tem um nome, que é para ter uma identidade. A relação educação com comunicação tem de ter uma identidade. Acho que a educomunicação é perfeita para chamar essas duas coisas. Embora, para alguns, possa ser tratado como rótulo, para mim, é a identidade dessa relação. (Informação pessoal) ${ }^{58}$.

Desde 2006, Lima passou a acumular também a função de presidente do Comitê Gestor do programa. O vice-presidente é Ismar de Oliveira Soares, coordenador do NCE, e a secretária é Terlânia Bruno, do Sindicato dos Jornalistas. Esse grupo de pessoas forma a diretoria executiva. Lima afirma que o Comitê começou legal, mas, depois, foi diminuindo, diminuindo. $\mathrm{O}$ fator apontado para essa diminuição foi as outras Secretarias não terem comprado a idéia da educomunicação e, por isso, não enviarem seus representantes para as reuniões. Por esses motivos, Lima (2008) acredita que:

[...] precisa fazer uma mudança na lei que fala do Comitê Gestor, para ele ter mais força política dentro da prefeitura. O Comitê é um órgão executivo que é gerido pela prefeitura. Então, precisa ter recurso. Precisa ter condições materiais para ter uma sede. Precisa ter voz ativa para poder indicar, fazer as indicações, já que a lei diz quais são as nossas atribuições. Mas a gente realmente não encontrou essa condição... Praticamente, o trabalho começou em 2006. Estamos há dois anos. E a gente ainda não encontrou meios para poder fazer essa articulação de fato... Para que fôssemos vistos como um parceiro no auxílio da questão de tentar a educomunicação como proposta de política pública para a saúde, para o esporte... (Informação pessoal) ${ }^{59}$.

Soares (2008) também vê o Comitê Gestor agindo aquém de suas expectativas. O motivo apontado também é a falta de autonomia que este adquiriu, mas, em função de ter um funcionário da Secretaria como presidente:

O próprio Comitê Gestor, que funcionaria com representantes das Secretarias, não funciona adequadamente. Ele existe, houve uma convocação inicial com representantes dos vários setores, mas que o próprio fato de ele ser presidido por alguém da Secretaria da Educação... A Secretaria da Educação entendeu que era melhor o professor Carlos [Lima] fosse o presidente desse Comitê. Eles indicaram alguém da Secretaria e não alguém externo. O projeto poderia ter um representante do Sindicato dos Jornalistas,

\footnotetext{
${ }^{58}$ Ibid.

${ }^{59}$ Ibid.
} 
dos professores ou da própria USP... Porque se entende que o Comitê Gestor tem de ter autonomia. No entanto, não é do interesse da Secretaria que o Comitê tivesse autonomia. Colocando um funcionário da Secretaria como presidente, ele ficaria subordinado diretamente.

O Comitê Gestor não está funcionando adequadamente pelo fato de estar localizado na Secretaria e pelo fato de as demais Secretarias não terem, não entenderem a importância desse projeto porque não houve uma articulação necessária para isso e as ações estão concentradas em uma pessoa. Simultaneamente, a lei projeta uma sombra. Projeta uma luz e uma sombra. A luz está alertando o Poder Público que ele não pode desconsiderar a existência do projeto. E uma sombra porque ele não permite uma autonomia da ação desse Comitê para que ele produza, produza, por exemplo, um folder com as ações. (Informação pessoal) ${ }^{60}$.

Lima (2008) também admitiu que Comitê Gestor não funciona bem. Um dos motivos que ele aponta para a inadequação das ações que o Comitê pudesse ter é a existência de conflito de interesses para definir qual feição o programa apresentaria como continuidade e sugere que, por conta disso, resultou também o desgaste do grupo:

Uma coisa que também acabou emperrando é o seguinte: no início da gestão do Comitê, foi colocada muito a questão do trabalho que a gente poderia desenvolver do Educom com as rádios comunitárias. A gente pode até apoiar e desenvolver uma estratégia da escola com as rádios comunitárias, mas não pode ser rádio comunitária... A gente não pode sair da escola. Acho que tem de ter uma coisa assim, um grupo... E a gente ficou batendo muito nisso... $\mathrm{E}$ acabou criando um mau entendimento... O Comitê Gestor estava querendo fazer as rádios dentro das escolas... E não era do meu interesse que isso acontecesse. Acho que a rádio comunitária tem de ser um parceiro em off... $\mathrm{Na}$ promoção da educação no bairro, sobretudo, captando as informações que são desenvolvidas na escola na rádio comunitária. Mas, tendo um grupo no bairro, de associações, que pudesse estar gerindo isso. E a educação, o rádio escolar teria de ser mais um ali. Não o gestor daquilo. Até que falaram: "Esses equipamentos poderiam se transformar em rádio comunitária". Transmissor precisa de liberação para mudar a chave para amplificar. Isso não pode ser feito dessa forma. Isso não é uma rádio comunitária. Isso é uma rádio local para desenvolver projetos internos. (Informação pessoal) ${ }^{61}$.

Os interesses em conflito mencionados por Lima correspondem à sua vontade, como coordenador do programa, frente à intenção da Oboré, em parceria com o Instituto Itaú Cultural, de conferir caráter de radiodifusão comunitária às rádios das escolas, conforme

\footnotetext{
${ }^{60}$ SOARES, I. Entrevista realizada por esta pesquisa em 26 de ago. 2008.

${ }^{61}$ LIMA, C. Entrevista realizada por esta pesquisa em 8 de set. 2008.
} 
diretrizes e intenções examinados nesta pesquisa em documento produzido pela Oboré, já comentado neste trabalho (página 83). Como se percebe no excerto acima e também em outras evidências colhidas, o que prevaleceu para a definição de como o programa passou a ser configurado na Secretaria Municipal de Educação de São Paulo foi a preferência de Lima.

Sobre os recursos orçamentários de que o programa dispõe, Lima (2008) indica as seguintes limitações:

Não é um recurso que a gente teve condições de contratação de parceiros para a formação e, diante dessa restrição, a gente acabou desenvolvendo uma estratégia de formação partindo do meu conhecimento de como é que lido com essas coisas junto à escola. Então, toda parte de formação quem faz sou eu junto aos gestores, os gestores do projeto junto à sua Coordenadoria fazem a multiplicação com os professores da escola, e os professores fazem isso com os alunos lá... Diferente, por exemplo, do projeto anterior que você tinha uma formação descentralizada, vinda do NCE, que era pago para fazer isso, e fez esse trabalho durante quatro anos de formação de nove ou foi onze mil pessoas no total. A gente não fez isso. A gente já formou muita gente com as novas formas de trabalhar o projeto. (Informação pessoal) ${ }^{62}$.

Nesse excerto, Lima chama atenção também para a maneira como passou a se dar a formação proposta pelo programa. Salienta que essa formação foi suscitada e decidida por ele, diante das limitações institucionais impostas. A formação assumiu as seguintes características: sem sistematização, sem agenda pré-definida, sem recursos financeiros para contratar serviços.

Quando a escola prefere que eu vá até ela, e eu tenho agenda, vou. Falo com os professores e, às vezes, com os alunos também. Quando tem a possibilidade de reunir os professores da escola numa região, vou até a região. Quando o professor quer vir aqui com os seus alunos, ele vem aqui, eu marco um dia e faço a formação aqui ou lá no laboratório. Então, não tem uma sistematização: "Olha, tal mês vai ter...". A gente atende segundas e quintas-feiras a formação para a rede. $\mathrm{E}$ os outros dias a gente vai fazendo. Aparece, a gente está próximo, a gente vai lá e dá a formação. São bastante curtas, é mais a parte prática. Depois, o restante das informações a gente veicula tudo na internet, no blog que eu fiz e outros caminhos que a gente tem aí, que é o e-group, que a gente criou, para poder dar assistência e informações para esses professores. À medida que esses professores fazem parte de uma formação, eles já integram nosso e-group e ali ele já recebe informações direto. O blog é uma outra forma de a gente socializar

\footnotetext{
62 Ibid.
} 
informação. Os tutoriais são uma outra forma de fazer isso. Assim a gente encurta a necessidade de ter dinheiro para desenvolver o projeto. Eu acho importante ter dinheiro para o projeto. Mas, quando não tem, a gente vai tentando usar uma alternativa criativa. (Informação pessoal) ${ }^{63}$.

Inquirido se teve de consultar alguém para operar as mudanças no programa, Lima (2008) afirma que houve apoio. Esse apoio seria da diretora de DOT:

Regina Lipi Suzuki, é ela a diretora de DOT. Ela que gosta do projeto. Graças a ela o sucesso do projeto naquilo que realmente coube à gente fazer. Com o apoio dela é que as coisas realmente caminharam por esse caminho. Se eu não tivesse apoio, autonomia para colocar o que eu penso do projeto, a gente não conseguiria se articular com tanta gente. (Informação pessoal) ${ }^{64}$.

Sejam essas diversas motivações que levaram à continuidade do programa, nesta pesquisa não se encontrou nenhum documento que comprovasse uma demanda pelos benefícios que por ventura pudessem ser alcançados com a implantação do programa nas escolas. A demanda não aparece como fator considerado para a decisão pela continuidade do programa. Talvez mais forte que a demanda, o fator marketing das ações do programa fosse mais determinante para a opção por sua permanência. No entanto, as considerações finais da entrevista de Soares apontam alguns fatores que, acredita, podem ter levado à decisão pela continuidade:

A lei é algo muito importante. Nenhuma prefeitura quer sofrer processo. Se a prefeitura não tomasse alguma providência, podiam vir ações públicas contra a prefeitura. Professores, pais de alunos, qualquer um poderia entrar com ação pública no tribunal pelo não cumprimento da lei. Então, eles cumprem a obrigação legal de tocar. A lei é importante. Segundo capítulo: a demanda. As escolas pedem. De tanto pedir ao Secretário, ele diz: "Olha, vamos fazer alguma coisa para não dizer que não estamos fazendo nada...". Terceiro lugar: o projeto tem dado visibilidade para as pessoas que estão nele. $\mathrm{O}$ Secretário vai à escola e lá tem um grupo de crianças que vai entrevistá-lo. $\mathrm{O}$ fato de uma autoridade ser cercada por crianças dá uma bela foto! Então, existe esse lado de marketing. Em quarto lugar, existe o envolvimento de professores e alunos que cria auto-estima naquele ambiente, daquele grupo, daquelas pessoas, e faz com que elas dêem continuidade. (Informação pessoal $)^{65}$.

\footnotetext{
63 Ibid.

64 Ibid.

${ }^{65}$ SOARES, I. Entrevista concedida a Mauro Soares Cordeiro em 26 de ago. 2008.
} 


\subsection{A PERMANÊNCIA DO PROGRAMA NAS ESCOLAS}

Nesta pesquisa, foi realizado contato telefônico com as escolas que receberam o equipamento de rádio previsto no contrato para a implantação do programa. No total, são 246 escolas com equipamentos. Esse levantamento visou dois objetivos: 1) verificar se havia ainda o equipamento na escola; e 2) se havia a possibilidade de aplicação de questionário junto às pessoas que se encarregaram da operacionalização do programa nas escolas. A fonte das informações referentes às escolas foi o documento Unidades educacionais participantes do projeto (SÃO PAULO, [2004a]), assim como listas de endereços e telefones das escolas no sítio da Secretaria Municipal de Educação. As primeiras ligações foram feitas durante o primeiro semestre de 2007, de março a maio.

Os telefones das escolas não estavam atualizados naquelas listas. São diversas listas com os telefones das escolas pesquisadas, no entanto, muitos estão errados. Foi tentado de outras formas: ligação para as Coordenadorias; pedir o telefone de uma escola em outra escola; consulta a outros sítios da internet. Muitos dos números de telefones corretos que faltavam foram encontrados. Seguiu-se assim uma quarta tentativa de contato com as escolas (nas outras três tentativas, não foi possível contato com 95 escolas. Outras 41 pediram para que ligasse em outro horário).

As perguntas realizadas durante o contato telefônico foram: a escola possui um responsável pelo programa Educom.rádio? Qual o cargo ou função na escola que essa pessoa exerce? Em que horário está na escola e em que horário, por ventura, poderia nos receber? Será possível encaminhar questionário em seu nome? O equipamento está instalado? Funciona? Se não está funcionando, qual o motivo? Estão desenvolvendo o programa? Qual outra forma de contato? O endereço da escola está correto? 
A partir das respostas obtidas com o primeiro contato, chegou-se a algumas evidências sobre o estado do programa naquele momento. Em 102 escolas, foi possível falar diretamente com a pessoa encarregada pelo programa: agente escolar, assistentes de direção, ATE (Assistente Técnico Educacional), coordenadores pedagógicos, docentes, docentes "readaptados", educadores comunitários, diretores, oficineiros ligados a ONGs, POIE (Professor Orientador de Informática Educacional), vice-diretores. Em outras 39 escolas, conseguiu-se (com outra pessoa) o nome e horário em que a pessoa encarregada pelo programa estaria na escola. Das 102 escolas em que foi possível conversar por telefone, 72 afirmaram que não estavam realizando o programa. Os motivos alegados no contato telefônico para o não funcionamento do programa na escola foram os seguintes: em 20, simplesmente não usam; em 13, não está instalado; em 11, falta de manutenção; em 10, transferência de professores responsáveis pelo programa; em 7, não tem responsável; em 4, "problema estrutural” (alguma reforma física); em 3, dificuldade de manuseio dos equipamentos; em 2, não há sala; em 1, "entraves burocráticos"; em 1, reorganizando o projeto. Seis escolas tiveram o equipamento roubado. Uma (Emef Vargem Grande, Capela do Socorro) teve o equipamento transferido para o CEU Três Lagos e outra (Emef Milton Campos) teve o equipamento transferido para outra escola (Emef Garcia D’Ávila).

Outro momento de contato telefônico com as escolas foi empreendido no primeiro semestre de 2008, entre maio e junho. Priorizaram-se as 95 escolas em que não foi possível contato naquela primeira vez e mais as 41 que pediram para que se ligasse em outro horário, ou seja, 136 escolas.

A partir do contato realizado e em posse dos endereços eletrônicos das escolas, conseguido por meio daquele contato, na primeira quinzena de agosto de 2008, foram enviadas mensagens com questionários para 49 escolas que afirmaram que o programa estava funcionando. 
Imediatamente, 7 endereços demonstraram alguma incorreção e as mensagens retornaram. Até o fim de agosto, 4 escolas enviaram o questionário respondido. Uma pessoa respondeu a uma das mensagens eletrônicas informando não fazer mais parte da equipe da escola, ou seja, havia informado o endereço eletrônico pessoal no momento do contato telefônico.

Das pessoas que atenderam ao telefonema empreendido por esta pesquisa, 41 disseram que achavam que o equipamento estava funcionando parcialmente, mas, que era necessário ligar novamente para falar com outra pessoa.

Assim, do total das 246 com equipamentos, de acordo com as respostas dadas pelas pessoas que atenderam ao telefone nas escolas (a pergunta era: “O programa funciona nesta escola?"), 142 disseram que não. Os motivos alegados foram: 78 disseram apenas que não está em uso; 2 informaram que falta lugar adequado; 1 alegou falta verba; 20 precisaram que não há pessoal disponível para operacionalizar o programa; 19 observaram que o equipamento necessita manutenção; outras 12 contaram que a mudança de equipe da escola era a responsável pelo não funcionamento; a reforma da escola aparece como justificativa para 3; 1 detectou que o equipamento se perdeu; 6 denunciaram que o equipamento foi roubado. Com 7 escolas, não foi possível nenhum tipo de contato.

Na primeira quinzena de outubro de 2008, foi realizada uma terceira empreitada de contatos telefônicos com as escolas. Dessa vez, o contato foi com 104 escolas em que havia a possibilidade de o programa estar em funcionamento: ou porque responderam a outros contatos afirmando que estava funcionando, mas, não responderam ao e-mail com o questionário; ou que pediram para ligar novamente; ou as que ainda não havia sido possível nenhum tipo de contato. Assim, dessas 104 escolas, 65 disseram que o programa não está funcionando. Dessa vez, os motivos alegados foram: 30 simplesmente não usam; 13 disseram ser a falta de pessoal responsável pelo programa o principal motivo; 9 disseram que foi a 
remoção da equipe; 5 relataram falta de espaço na escola para a montagem do estúdio de rádio; 5 disseram que o programa não foi retomado em 2008; 1 disse que faltaram aulas práticas com o equipamento; 1 contou que teve os equipamentos roubados; 1 não usa por falta de reparos.

Dessas 104, 39 escolas informaram que o programa estava em funcionamento. Com esse contato, foi possível conseguir o endereço eletrônico da escola, e a mensagem contendo o questionário foi encaminhada ao responsável pelo programa anunciado pelo informante da escola (sobretudo, diretoras e coordenadoras pedagógicas), na primeira quinzena de novembro de 2008.

Até 20 de dezembro de 2008, foram recebidos como retorno 13 questionários respondidos pelas pessoas encarregadas da operacionalização do programa nas escolas. Dessas, 13 responderam que o equipamento está instalado ${ }^{66} ; 8$ responderam que o equipamento está em perfeitas condições de $u s o^{67} ; 5$ responderam que não está em condições. Sobre o uso do equipamento, 11 escolas responderam que fazem uso freqüente. No entanto, os usos apontados são os mais variados: 2 responderam passar música nos intervalos. Cada uma das outras 9 escolas respondeu que: usa duas vezes por semana, das 11 às $15 \mathrm{~h}$; usa para música e informações nos intervalos diariamente; para montagem de programas; usa três vezes por semana, no intervalo escolar; para cursos e no intervalo; para transmissão radiofônica; usa nos intervalos; usa no período da manhã para execução de programas; realiza programação musical, recados diversos, divulgação de campanhas, das $15 \mathrm{~h} 45$ às $16 \mathrm{~h} 15$, diariamente. A respeito da pergunta se o programa tem sido executado de alguma maneira, 6 escolas responderam que sim. O uso também é distinto entre elas: duas disseram realizar rádio on-line

\footnotetext{
${ }^{66}$ Por está instalado, pressupõe-se que o equipamento de produção e transmissão possui uma sala; que a antena que transmite para as caixas de som esteja fixada; que as caixas de som que recebem o sinal do transmissor estejam fixadas.

${ }^{67} \mathrm{Ou}$ seja, além de contar com as especificidades da instalação descrita acima, têm seus componentes em condições de uso
} 
(chamada de podcasting - é uma forma de publicação de arquivos em formato digital na internet); uma relatou que usa em sala de aula, para gravação de programas com gravador de mão; outra disse que usa em eventos da escola; outra, para comemorações festivas; uma contou que a rádio fica disponível também ao grêmio estudantil, em festas e eventos diversos. 


\section{CONCLUSÃO}

A pesquisa apresentada neste trabalho se empenhou em responder ao seguinte problema: a forma de elaboração do programa Educom.rádio influiu muito na sua continuidade?

Foi considerada como hipótese principal que formas de elaboração de programas influem em sua continuidade. Definiu-se por forma de elaboração a participação na elaboração, entendendo que quanto maior o número e mais variados os tipos de agentes participantes da elaboração de uma política, programa ou projeto, mais numerosos e variados agentes tenderão a querer a realização do que foi elaborado, portanto, a inclinar-se por sua permanência.

Ainda que a pesquisa tenha dedicado atenção concentrada no fator participação na elaboração de programas, distinguiram-se outros fatores que concorrem para a continuidade de um programa: a legislação; a abrangência de benefícios; a dotação orçamentária. Quando se trata de legislação, governantes podem ser obrigados a criar ou implementar programas por imposição de lei, o que lhes conferirá continuidade independente das preferências de ocupantes do poder executivo. A respeito da abrangência de benefícios, quanto maior o número de pessoas e mais variados os grupos que se beneficiem de uma política, programa ou projeto, mais numerosos e variados agentes tenderão a inclinar-se por sua permanência. A dotação orçamentária refere-se ao fato de que os recursos financeiros são indispensáveis à realização de uma política, programa ou projeto, mas, podem reduzir-se ou estar indisponíveis ainda que haja forte consenso sobre a necessidade de sua permanência.

Para caracterizar a forma de elaboração do programa Educom.rádio quanto ao número e variedade de indivíduos e grupos participantes, o trabalho se baseou nas entrevistas realizadas com as pessoas que participaram da tomada de decisão sobre o programa. Os depoimentos obtidos foram interpretados de modo a evidenciar a quantidade e os tipos de indivíduos e 
grupos que participaram da elaboração do programa, bem como balizar as diretrizes e critérios envolvidos nas decisões que levaram à adoção do programa e à sua continuidade. Essas pessoas a entrevistar foram identificadas por meio dos documentos oficiais que foram produzidos sobre o programa. Os documentos foram examinados também com a finalidade de identificação dos agentes que participaram das decisões e para atribuir pesos à atuação dos diferentes agentes envolvidos tanto na elaboração quanto na continuidade do programa Educom.rádio.

Os dados que foram apurados pelo levantamento por questionário junto às escolas foram cotejados de maneira a poder afirmar que a continuidade do programa se dá também na sua operacionalização direta com a população beneficiária. Isso foi aferido em termos da regularidade do funcionamento das rádios nas escolas: das 246 escolas com equipamento, 39 responderam por telefone que o programa é executado em suas dependências. Dessas, 13 precisaram com algum detalhe, por meio de questionário enviado pelo endereço eletrônico, fazer uso freqüente da emissora de rádio em ambiente escolar.

Quanto aos grupos que participaram diretamente da elaboração do programa, a pesquisa constatou que foram pessoas ligadas ao NCE e ao Projeto Vida. Ligados ao NCE, as pessoas eram um professor universitário, Ismar de Oliveira Soares, e duas estudantes de mestrado em comunicação, Grácia Lima e Patrícia Alves. Do Projeto Vida, faziam parte Dirce Gomes e Sonia Almeida, juntamente com uma equipe formada por: Braz Nogueira, Marcos Volpi, Mário Rudolf e Marilândia Frazão. No entanto, os dados apurados levam a concluir que a decisão política fundamental sobre o formato do programa foi tomada pela relação estabelecida entre a coordenadora do Projeto Vida, Dirce Gomes, e o coordenador do NCE, Ismar de Oliveira Soares. 
Diante desse fato, pode-se afirmar que não participou da elaboração do programa um conjunto numeroso de pessoas e tão pouco de variados tipos.

Gomes foi a principal promotora de relações e decisões que levaram à elaboração e implantação do programa. Foi ela quem colocou recursos disponíveis ao NCE quando convidou Soares para a elaboração do programa. Ela estabeleceu também contato com o vereador Neder para a elaboração do projeto de lei que culminaria na Lei $\mathrm{n}^{\circ} 13.941$, que instituiu o Programa Educom no Município de São Paulo, em 2004. Acionou, assim, as estruturas do poder institucional para as elaborações aqui tratadas, bem como suscitou vínculos entre os atores que pressionariam pela continuidade do programa.

Mesmo saindo da Secretaria Municipal de Educação de São Paulo em 2003, ela impeliu ações que se configuraram como fatores que levaram à continuidade do programa.

Depois de Gomes, Neder, primeiro por meio de seu mandato como vereador (2001-2004) e, depois, como deputado estadual (a partir de 2005), é quem mais mobilizou recursos para manter o programa como política da Secretaria Municipal de Educação de São Paulo. O projeto de lei de sua autoria, proposto em 2002 na Câmara Municipal de São Paulo, é que se tornou a Lei $\mathrm{n}^{\mathrm{o}}$ 13.941. Com a mudança de prefeitos, seu mandato como deputado exerce influência sobre o Secretário Municipal de Educação para a continuidade do programa.

A Lei $n^{\circ} 13.941$ se constituiu como um dos principais fatores para a decisão pela continuidade do programa, como foi aferido pelas entrevistas realizadas. Com a pressão exercida pelos vínculos criados em torno do mandato do deputado Carlos Neder, o prefeito José Serra é levado a assinar o Decreto $\mathrm{n}^{\circ}$ 46.211, que regulamenta em caráter permanente o Programa Educom - Educomunicação pelas ondas do rádio. 
Outro grupo que exerceu pressão sobre o Secretário Municipal de Educação para continuidade do programa, mas, que não participou de sua elaboração, foi a Oboré. Essa empresa produziu documentos sobre o estado do programa Educom.rádio em 2005, propôs novas abordagens e estabeleceu nexos com outros projetos, e participou de reuniões com o deputado Neder para a configuração do Comitê Gestor do programa. Elaborou também uma série de eventos sobre comunicação social em que envolvia pessoas ligadas ao programa Educom.rádio, radiodifusão comunitária e também o Secretário Municipal de Educação de São Paulo (entre 2005 e 2006), José Aristodemo Pinotti. O conjunto dessas atividades parece ter contribuído para colocar o assunto da continuidade do programa no rol de preocupações daquele Secretário.

Soares foi o único que, tendo participado da elaboração do programa, seguiu exercendo influência de diversas formas para sua continuidade. Elaborou o programa como representante do NCE juntamente com o Projeto Vida; foi responsável pela supervisão da implantação; foi consultor para a justificativa do projeto de lei, do texto da lei, assim como do texto que constituiu o decreto que regulamentou a lei sobre o programa; é vice-presidente do Comitê Gestor do programa.

A pesquisa não teve contato com documentos que revelassem a preocupação com a permanência ou algum tipo de manifestação de opiniões produzidas pelos beneficiários do programa. Apenas as declarações de dois dos entrevistados aludiram à demanda por benefícios alcançados pelo programa como hipótese para ele ter adquirido continuidade. No entanto, não souberam precisar ou indicar evidências que comprovassem tal suposição.

Assim, conclui-se que as decisões fundamentais concernentes ao programa Educom.rádio, tanto para o processo de elaboração quanto para sua continuidade, foram tomadas por diretrizes e critérios de poucas pessoas, todas situadas no nível superior do setor educacional do município de São Paulo. 
Ainda que tenha havido a intenção de comparação do processo aqui examinado com outro estudo de política implantada pela Secretaria Municipal de Educação de São Paulo, os resultados obtidos não autorizam a fazer generalizações sobre políticas públicas do setor educacional. Todavia, pode-se observar que, tanto no programa Sala de Leitura como neste aqui, o fator forma de elaboração entendida como a participação na elaboração não foi preponderante para a continuidade dos programas. 


\section{REFERÊNCIAS}

ANDRADE, R. C. Processos decisórios na Câmara dos Vereadores e na Assembléia Legislativa de São Paulo. In: ANDRADE, R. C. et al. (Org.). Processo de governo no município e no Estado: uma análise a partir de São Paulo. São Paulo: Edusp, 1998. p. 15-40.

ARON, R. Estudos sociológicos. Rio de Janeiro: Bertrand Brasil, 1991. 304 p.

CALDEIRA, T. P. R. Cidade de muros: crime, segregação e cidadania em São Paulo. São Paulo: Ed. 34; Edusp, 2000. 400p.

COUTO, C. G. Constituição, competição e políticas públicas. Lua Nova: Revista de Cultura e Política, São Paulo, n. 65, p. 95-135, maio 2005. Quadrimestral.

DAHL, R. A. A moderna análise política. Rio de Janeiro: Lidador, 1966. 192 p.

DEBARBIEUX, É. Violência nas escolas: divergências sobre palavras e um desafio político. In: BLAYA, C.; DEBARBIEUX, É. (Orgs.) Violência nas escolas e políticas públicas. Brasília: Unesco, 2002. p. 59-92.

FUKS, Mario. Definição de agenda, debate público e problemas sociais: uma perspectiva argumentativa da dinâmica do conflito social. Boletim Informativo e Bibliográfico de Ciências Sociais, Rio de Janeiro, n. 49, p.79-94, $1^{\circ}$ sem. 2000. Semestral.

GHANEM, E. Mudança educacional: inovação e reforma: relatório científico 2: final. São Paulo, 2006. 434 p.

GHANEM, E. Influir em políticas prestando serviços a órgãos públicos? In: GHANEM, E. (Org.). Influir em políticas públicas e provocar mudanças sociais: experiências a partir da sociedade civil. São Paulo: Ashoka; Avina; Imprensa Oficial do Estado de São Paulo, 2007. p. 99-107.

GONÇALVES, L. R. O.; SPOSITO, M. Iniciativas públicas de redução da violência escolar no Brasil. Cadernos de Pesquisa, São Paulo, nº 115, p.101-138, mar. 2002. Quadrimestral.

LAMOUNIER, B. Análise de políticas públicas: quadro teórico-metodológico de referência. In: FUNDAP. Planejamento e políticas públicas. São Paulo: Fundação do Desenvolvimento Administrativo - Fundap, 1982. p. 5-21.

LINDBLOM, C. E. O processo de decisão política. Brasília: Unb, 1981. 124 p.

LIMA, G. L.; MELO, T. Educomunicação e meio ambiente. In: MELLO, S. S.; TRAJBER, R. Vamos cuidar do Brasil: conceitos e práticas em educação ambiental na escola. Brasília: Ministério da Educação, Coordenação Geral de Educação Ambiental: Ministério do Meio Ambiente, Departamento de Educação Ambiental : Unesco, 2007. p. 168-175. (Disponível também em:

$<$ http://portal.mec.gov.br/secad/arquivos/pdf/educacaoambiental/educacaoambiental_naescola .pdf>. Acesso em: 15 set. 2008.) 
LOWI, T. O Estado e a ciência política ou como nos convertemos naquilo que estudamos. Revista Brasileira de Informação Bibliográfica em Ciências Sociais, São Paulo; Rio de Janeiro, n. 38, p.3-14, jul. 1994. Semestral.

MARQUES, E. C. Redes sociais e poder no Estado brasileiro: aprendizados a partir das políticas urbanas. Revista Brasileira de Ciências Sociais, São Paulo, v. 21, n. 60, p.15-41, fev. 2006. Quadrimestral.

MELO, Marcus André. Estado, governo e políticas públicas. In: MICELI, S. O que ler na ciência social brasileira (1970-1995). São Paulo; Brasília: Sumaré; Anpocs \& Capes, 2000. p. 59-100. (Ciência Política, vol. III)

PERALVA, A. Violência e democracia: o paradoxo brasileiro. Rio de Janeiro: Paz e Terra, 2000. 227 p.

RUS PEREZ, José Roberto. Reflexões sobre a avaliação do processo de implementação de políticas e programas educacionais. In: WARDE, Mirian Jorge. Novas políticas educacionais: críticas e perspectivas. São Paulo: Programa de Estudos Pós-graduados em Educação: História e Filosofia da Educação da Pontifícia Universidade Católica de São Paulo, 1998. p. 139-145.

SCHILLING, F. Sociedade da insegurança, violência na escola. São Paulo: Editora Moderna, 2004. 110 p.

SCHWARTZENBERG, R.-G. Sociologia política: elementos de ciência política. São Paulo; Rio de Janeiro: Difel, 1979. 700 p.

SILVA, C. C. et al. Educação na capital paulista: um ensaio avaliativo da política municipal (2001-2002). São Paulo: Instituto Pólis; Puc-sp, 2004. 76 p. (Observatório dos Direitos do Cidadão: acompanhamento e análise das políticas públicas da cidade de São Paulo, 20).

SIMON, H. A. Comportamento administrativo: Estudo dos processos decisórios nas organizações administrativas. Rio de Janeiro: Fundação Getúlio Vargas, 1965. 312 p.

SOUZA, C. Política pública e orçamento público: conflitos e cooperação. In: BENEVIDES, M. V.; KERCHE, F.; VANNUCHI, P. Reforma política e cidadania. São Paulo: Fundação Perseu Abramo; Instituto Cidadania, 2003. p. 134-161.

VIANA, A. L. Abordagens metodológicas em políticas públicas. Rap: Revista de Administração Pública, Rio de Janeiro, v. 30, n. 2, p.5-43, mar. 1996. Bimestral.

WAISELFISZ, J. J.; MACIEL, M. Revertendo violências, semeando futuros: avaliação de impacto do Programa Abrindo Espaços no Rio de Janeiro e em Pernambuco. Brasília: Unesco, 2003. $120 \mathrm{p}$.

Teses e dissertações

ABBONIZIO, A. C. O. Orientações da parceria entre poder público e organizações sociais no Mova-SP. 2007. 107 f. + anexos. Dissertação (Mestrado) - Faculdade de Educação da Universidade de São Paulo, São Paulo, 2007. 
ALVES, P. H. Educom.rádio: uma política pública em educomunicação. 2007. 229 f. Tese (Doutorado) - Escola de Comunicações e Artes da Universidade de São Paulo, São Paulo, 2007.

FUNARI, C. V. A prática da mediação em processos educomunicacionais: o caso do projeto Educom.rádio. 2007. 262 f. Dissertação (Mestrado) - Escola de Comunicações e Artes da Universidade de São Paulo, São Paulo, 2007.

MENDES, M. F. V. Sala de leitura nas escolas da rede municipal de ensino de São Paulo: uma inovação que resiste às descontinuidades políticas. 2006. 385 f. + anexos. Tese (Doutorado) - Pontifícia Universidade Católica de São Paulo, São Paulo, 2006.

TAVARES JUNIOR, R. Educomunicação e expressão comunicativa: a produção radiofônica de crianças e jovens no projeto Educom.rádio. 2007. 274 f. Dissertação (Mestrado) - Escola de Comunicações e Artes da Universidade de São Paulo, São Paulo, 2007.

\section{Documentos oficiais}

COLIGAÇÃO MUdA SÃO PAULO PT, PC do B, PCB, PHS. Programa de governo prefeita Marta. São Paulo, 2000. 37 p.

FUSP - FUNDAÇÃO DE APOIO À UNIVERSIDADE DE SÃO PAULO. Termo de encerramento de participação no programa Educom.rádio. São Paulo, 28 de abril de 2006. 1 p.

NCE-ECA/USP. Novas ondas: gestão de comunicação, via rádio, em escola numa situação de conflito. São Paulo, 2001, 21 p.

Orientações de atividades: material para a equipe do projeto. São Paulo, 2004, 106

p.

Programa Educom: educomunicação pelas ondas do rádio: construindo a paz pela comunicação. São Paulo, 2001a. 10 p.

OBORÉ. Educom.rádio e sua interface com o Onda Cidadã. São Paulo, 2005, 74 p.

PROJETO ESPECIAL DE AÇÃO: unidade escolar: Emef Benedito de Jesus Batista Laurindo. Drem 08, São Paulo, 2001. 4 p.

SÃO PAULO (CIDADE). SECRETARIA MUNICIPAL DE EDUCAÇÃO. Como surgiu o Educom.rádio na rede municipal de educação? São Paulo, 28 de maio de 2002. 2 p. (SÃO PAULO, 2002, ) 2004a. 3 p.

Diretoria da Divisão de Ensino Fundamental. Relatório conclusivo. São Paulo, $2005.70 \mathrm{p}$.

DOT - Diretoria de Orientação Técnica. Proposta de Formação 2005. São Paulo,

Gabinete. Ata da primeira Reunião do Conselho Gestor do Programa Educom “Educomunicação nas Ondas do Rádio". São Paulo, 2006. 7 p. 
Projeto Pela Vida, Não à Violência. São Paulo, 1992. 33 p.

. Projeto Educom.rádio. Unidades educacionais participantes do projeto. São

Paulo, [2004a]. 11 p.

Projeto Vida. São Paulo, [2003]. 11 p.

Paulo, 2004. 4 p.

Projeto Vida. Demonstrativo das ações do Projeto Vida de 2001 a 2004. São

Projeto Vida. Gestão 2001-2004. São Paulo, [2004]. 13 p.

SÃO PAULO (CIDADE). SECRETARIA MUNICIPAL DE SEGURANÇA URBANA.

Estatuto da Criança e Adolescente (ECA). São Paulo, 2000. 160 p.

Sítios

BRASIL. Tribunal Superior Eleitoral. Resultado das eleições. Disponível em:

$<$ http://www.tse.gov.br/sieeseireweb/seire.jsp?modulo=RE\&anoConexao=2000>. Acesso em: 15 set. 2008 .

BRASIL. Avança Brasil - Justiça e Segurança. Programa Paz nas Escolas. Disponível em: $<$ http://www.abrasil.gov.br/nivel3/index.asp?cod=NOTIC\&id=255>. Acesso em: 15 set. 2008a.

NEDER, Carlos. Trajetória Política. Disponível em:

$<$ http://www.carlosneder.com.br/CN01/FIX_det.asp?id=1>. Acesso em: 15 set. 2008a.

NEDER, Carlos. Seminário do Programa Nas Ondas do Rádio: A Mídia e a Tecnologia no Espaço Escolar. Disponível em:

$<$ http://www.carlosneder.com.br/upload/downloads/FolderEducomSeminarioMarco2008.pdf>. Acesso em: 15 set. 2008 b.

FUSP - FUNDAÇÃO DE APOIO À UNIVERSIDADE DE SÃO PAULO (São Paulo). Descrição do projeto 710: Educomunicação pelas ondas do rádio - construindo a paz pela comunicação. Disponível em: <http://www.fusp.org.br/detproj-1.php3?wcodigo=710>. Acesso em: 15 set. 2008.

OBORÉ (São Paulo). Notícias. Disponível em:

<http://www.obore.com.br/aconteceIntegra.asp?cd=869>. Acesso em: 15 set. 2008.

PARTIDO DOS TRABALHADORES. Estatuto. Disponível em:

$<$ http://www.pt.org.br/portalpt/images/stories/textos/estatutopt.pdf>. Acesso em: 15 set. 2008.

SÃO PAULO (CIDADE). Secretaria Municipal de Educação. Nas ondas do rádio.

Disponível em: <http://portaleducacao.prefeitura.sp.gov.br>. Acesso em: 15 set. 2008.

Câmara Municipal de São Paulo. Processo Legislativo. Disponível em:

$<$ http://www.camara.sp.gov.br/processolegislativo.asp>. Acesso em: 15 set. 2008a.

Decretos, leis, portarias (Legislação) 
SÃO PAULO (CIDADE). Lei no 13.941, de 28 de dezembro de 2004, Institui o Programa EDUCOM-Educomunicação pelas ondas do rádio, no Município de São Paulo, e dá outras providências. Diário Oficial do Município de São Paulo, São Paulo, SP, 29 dez. 2004b. Seção 1, p. 1.

Decreto $\mathrm{n}^{\circ}$ 46.211, de 15 de agosto de 2005, Regulamenta o Programa EDUCOM Educomunicação pelas ondas do rádio, instituído no Município de São Paulo pela Lei ${ }^{\circ}$ 13.941, de 28 de dezembro de 2004. Diário Oficial da Cidade de São Paulo, São Paulo, SP, 16 ago. 2005a. p. 44.

. CÂMARA MUNICIPAL DE SÃO PAUlO. Projeto de Lei no 556/02, São Paulo, 24 de setembro de 2002a. 4 p.

Portaria 8083, de 21 de dezembro de 2005, Constitui no âmbito da Prefeitura do Município de São Paulo e vinculado à Secretaria Municipal de Educação, o Comitê Gestor encarregado da implantação e implementação do Programa EDUCOM - Educomunicação pelas ondas do rádio. Diário Oficial da Cidade de São Paulo, São Paulo, SP, 22 dez. 2005b. p. 6. 


\section{APÊNDICE}

\section{Pessoas entrevistadas}

Carlos Lima - coordenador do programa Educom.rádio na Secretaria Municipal de Educação de São Paulo desde 2006. É também presidente do Comitê Gestor do programa desde sua institucionalização. É professor de escola municipal da Capital.

Carlos Neder - vereador eleito (PT) para o mandato de 2001 a 2004 (pela segunda vez. Tinha sido eleito vereador também em 1996). Em 2001, tornou-se líder da bancada do PT na Câmara Municipal de São Paulo. Foi Chefe de Gabinete da prefeita Luiza Erundina (1989) e Secretário Municipal da Saúde (1990-1992). Tomou posse como deputado estadual pelo PT em 6 de janeiro de 2005. É mestre em Saúde Pública pela Unicamp.

Claudemir Viana - foi coordenador pedagógico do programa Educom.rádio do segundo semestre de 2003 até o fim de 2004. É doutor em comunicação pela ECA-USP.

Dirce Gomes - coordenadora do Projeto Vida 2001-2002. Foi do Gabinete da Conae durante o governo de Luiza Erundina (1989-1992).

Fátima Mohamed Younis - professora de escola municipal do município de São Paulo, que primeiro fez contato com o Projeto Vida.

Fernando José de Almeida - Foi Secretário de Educação do Município de São Paulo entre 2001 e 2002. Até 2001, dirigia a Escola Nossa Senhora das Graças. É também docente em 
pós-graduação, na Pontifícia Universidade Católica de São Paulo (PUC-SP), e vice-presidente da Fundação Padre Anchieta - Rádio e TV Cultura.

Grácia Lopes Lima - foi uma das elaboradoras do programa Educom.rádio. Foi coordenadora pedagógica do programa desde seu início até o primeiro semestre de 2003. É mestre em comunicação pela ECA e doutoranda pela Faculdade de Educação da USP. Desenvolve o projeto Cala-boca já morreu.

Ismar de Oliveira Soares - coordenador do Núcleo de Comunicação e Educação da ECA (Escola de Comunicações e Artes) da Universidade de São Paulo desde 1997. Foi um dos elaboradores do programa Edudom.rádio, coordenou sua implantação entre 2001 e 2004 e passou a ser vice-presidente do Comitê Gestor do programa em 2006. É também professor da ECA.

Marívia Torelli - foi diretora da Diretoria de Orientação Técnica da Secretaria Municipal de Educação de São Paulo entre 2002 e 2004. É supervisora de Ensino na Diretoria de Educação do Carrão.

Matias Vieira - coordenador do Projeto Vida entre novembro de 2003 e setembro de 2004. Foi diretor da Emef Padre Benedito Batista Laurindo de Jesus em 1999. Em 2001, assumiu a Coordenadoria de Educação de Vila Prudente /Sapopemba e ficou até janeiro de 2003. A partir de setembro de 2004, assumiu a Chefia do Gabinete da Subprefeitura Mooca. Em 2008, trabalha na Emef Arquiteto Vilanova Artigas. 